\title{
Resistance to Macrolide Antibiotics in Public Health Pathogens
}

\author{
Corey Fyfe, Trudy H. Grossman, Kathy Kerstein, and Joyce Sutcliffe
}

Tetraphase Pharmaceuticals, Watertown, Massachusetts 02472

Correspondence: jsutcliffe@tphase.com

\begin{abstract}
Macrolide resistance mechanisms can be target-based with a change in a $23 \mathrm{~S}$ ribosomal RNA (rRNA) residue or a mutation in ribosomal protein L4 or L22 affecting the ribosome's interaction with the antibiotic. Alternatively, mono- or dimethylation of A2058 in domain $V$ of the $23 \mathrm{~S}$ rRNA by an acquired rRNA methyltransferase, the product of an erm (erythromycin ribosome methylation) gene, can interfere with antibiotic binding. Acquired genes encoding efflux pumps, most predominantly mef(A) $+m s r(\mathrm{D})$ in pneumococci/streptococci and $\operatorname{msr}(\mathrm{A} / \mathrm{B})$ in staphylococci, also mediate resistance. Drug-inactivating mechanisms include phosphorylation of the 2'-hydroxyl of the amino sugar found at position C5 by phosphotransferases and hydrolysis of the macrocyclic lactone by esterases. These acquired genes are regulated by either translation or transcription attenuation, largely because cells are less fit when these genes, especially the rRNA methyltransferases, are highly induced or constitutively expressed. The induction of gene expression is cleverly tied to the mechanism of action of macrolides, relying on antibiotic-bound ribosomes stalled at specific sequences of nascent polypeptides to promote transcription or translation of downstream sequences.
\end{abstract}

\begin{abstract}
acrolide antibiotics are polyketides composed of a 14-, 15-, or 16-membered macrocyclic lactone ring (14-, 15-, and 16-membered) to which several sugars and/or side chains have been attached by the producing organism or as modifications during semisynthesis in the laboratory (Figs. 1 and 2). Newer semisynthetic derivations, like ketolides telithromycin, and solithromycin, have a C3-keto group in place of the $\mathrm{C} 3$ cladinose (akin to naturally occurring pikromycin) (Brockmann and Henkel 1950) and an 11,12-cyclic carbamate with an extended alkyl-aryl side chain that increases the affinity of the antibiotic for the ribosome by 10- to 100-fold (Hansen et al. 1999;
\end{abstract}

Dunkle et al. 2010); in the case of solithromycin, a fluorine substituent at $\mathrm{C} 2$ provides an additional ribosomal interaction (Llano-Sotelo et al. 2010). Macrolides continue to be important in the therapeutic treatment of community-acquired pneumonia (Streptococcus pneumoniae, Haemophilus influenzae, Moraxella catarrhalis, and atypicals Legionella pneumophila, Mycoplasma pneumoniae, Chlamydia pneumoniae), sexually transmitted diseases (Neiserria gonorhoeae, Chlamydia trachomatis, Mycoplasma genitalium), shigellosis, and salmonellosis. With solithromycin heading for a new drug application (NDA) filing in 2016 and having the in vitro potency to treat erythromycin-resistant

Editors: Lynn L. Silver and Karen Bush

Additional Perspectives on Antibiotics and Antibiotic Resistance available at www.perspectivesinmedicine.org

Copyright (C) 2016 Cold Spring Harbor Laboratory Press; all rights reserved; doi: 10.1101/cshperspect.a025395 Cite this article as Cold Spring Harb Perspect Med 2016;6:a025395 
C. Fyfe et al.

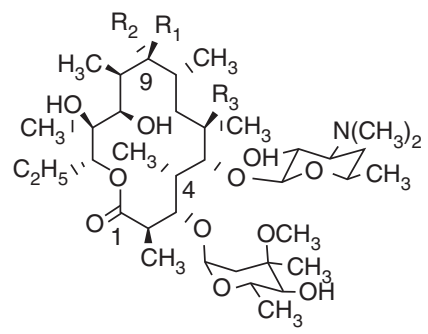

\begin{tabular}{llll} 
& $\mathrm{R}_{1}$ & $\mathrm{R}_{2}$ & $\mathrm{R}_{3}$ \\
\hline Erythromycin & $\mathrm{O}$ & $\mathrm{O}$ & $\mathrm{OH}$ \\
Clarithromycin & $\mathrm{O}$ & $\mathrm{O}$ & $\mathrm{OCH}_{3}$ \\
Roxithromycin & $\mathrm{NOCH}_{2} \mathrm{OC}_{2} \mathrm{H}_{4} \mathrm{OCH}_{3}$ & $\mathrm{OH}$ \\
\hline
\end{tabular}
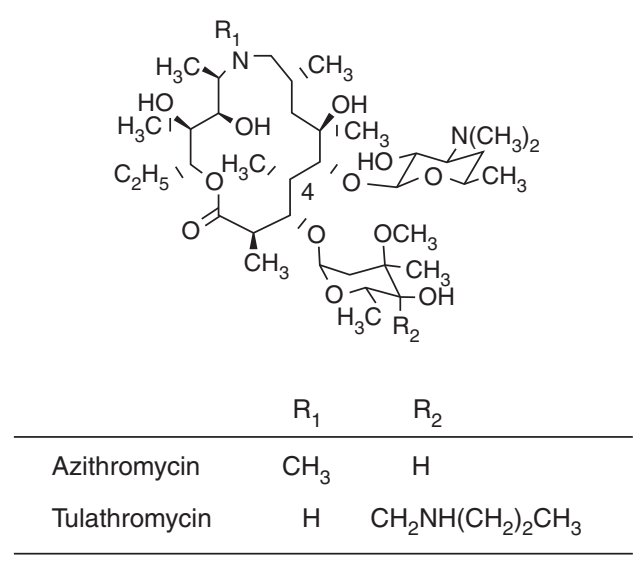
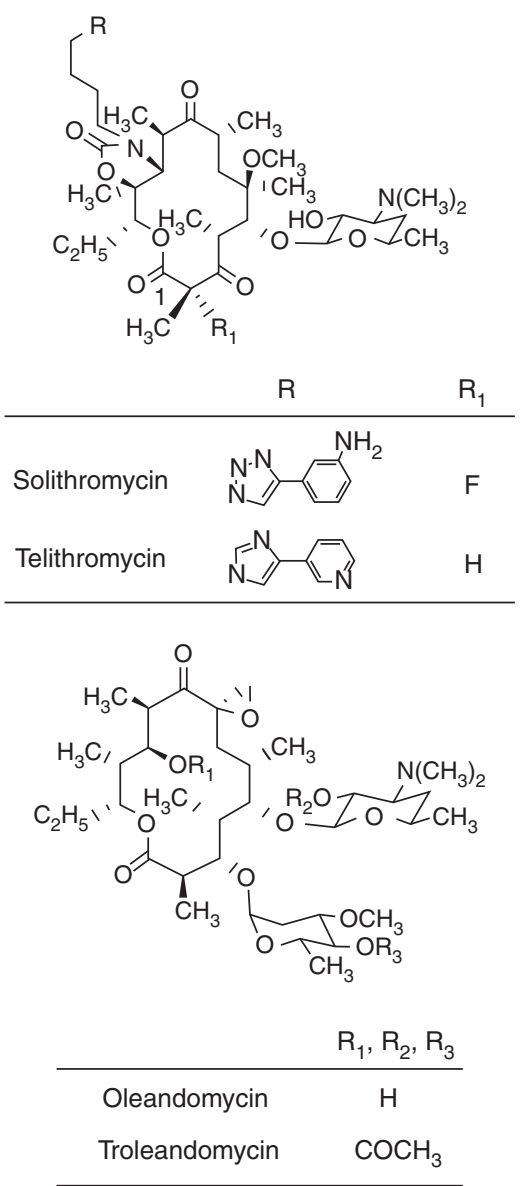

Figure 1. Structures of 14- and 15-membered macrolides.

pneumococci and gonococci (Farrell et al. 2015; Hook et al. 2015), macrolides/ketolides will continue as an important part of the antibiotic armamentarium.

The mechanism of action of macrolides has been further refined through a combination of genetic, biochemical, crystallographic, and ribosome profiling studies (Tu et al. 2005; Dunkle et al. 2010; Kannan et al. 2012, 2014; Gupta et al. 2016). Macrolides/ketolides are sensed by the ribosome and, in the presence of certain macrolide-stalling nascent amino acid chaindependent motifs, selectively inhibit protein synthesis. Further, and to different extents, ketolides and macrolides cause frameshifting, leading to aberrant protein synthesis.
Shortly after its clinical debut in 1953, resistance to erythromycin in staphylococci was described and was likely mediated by methylation of the 23S ribosomal RNA (rRNA) at nucleotide A2058 (Escherichia coli numbering) encoded by an erythromycin ribosomal methyltransferase (erm) gene (Weisblum 1995a). Erm methyltransferases add one or two methyl groups to the N-6 exocyclic amino group of A2058, disrupting the key hydrogen bond between A2058 and the desosamine sugar at C5 (Fig. 3). Ribosomal methylation by methyltransferases encoded by erm genes remains the most widespread macrolide resistance in pathogenic bacteria, with certain erm genes more predominantly found in some species. Streptococci 
Resistance to Macrolide Antibiotics in Public Health Pathogens

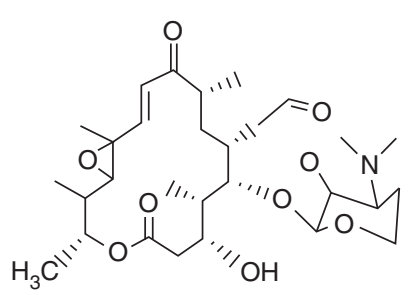

Rosamicin

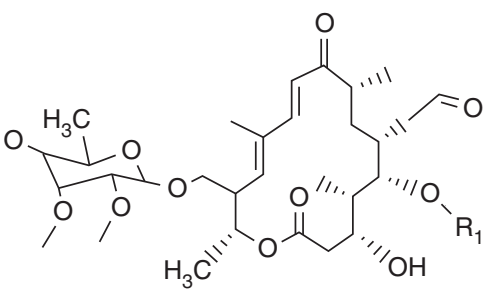

Tilmicosin

Tylosin

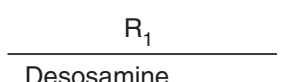

Mycaminose-mycarose

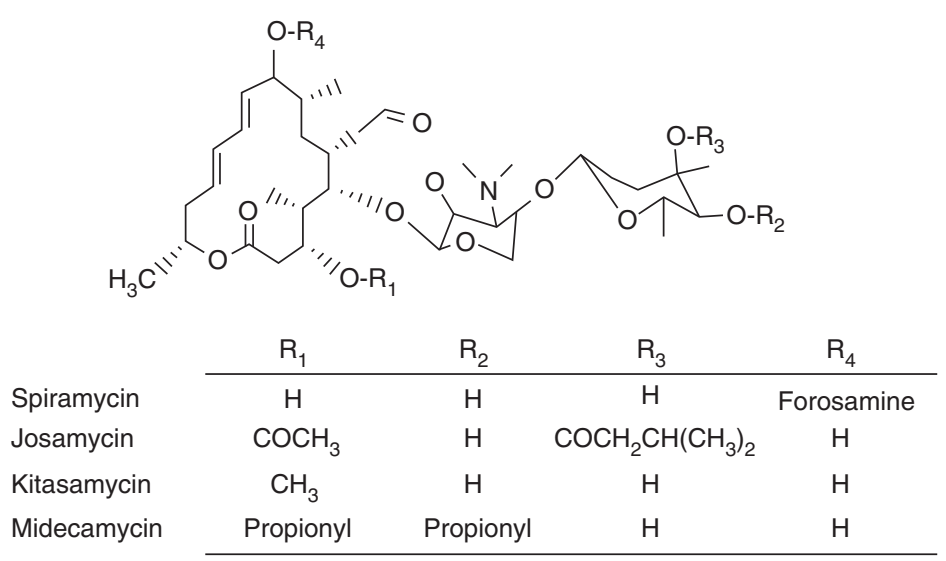

Figure 2. Structures of 16-membered macrolides.

generally have $\operatorname{erm}(\mathrm{B})$ or $\operatorname{erm}(\mathrm{A})$, subclass $\operatorname{erm}(\mathrm{TR})$, whereas $\operatorname{erm}(\mathrm{A}), \operatorname{erm}(\mathrm{B})$, or $\operatorname{erm}(\mathrm{C})$ are found in staphylococci and erm $(\mathrm{F})$ in anaerobes and $H$. influenzae (Table 2, and references therein; see also faculty.washington.edu/ marilynr). There can be either mono- or dimethylation of A2058 and the degree of rRNA dimethylation can determine ketolide resistance (Douthwaite et al. 2005). Most erm genes are inducible by 14 - and 15-membered macrolides, whereby translation repression of the erm methyltransferase gene, because of the sequestration of its ribosome-binding site (RBS) by messenger RNA (mRNA) secondary structure, is relieved by binding of the inducer to the ribosome (Horinouchi and Weisblum 1980; Depardieu et al. 2007; Subramaniam et al. 2011). Upstream of the start codon of a methyltransferase gene is an open reading frame (ORF) that produces leader peptides of different lengths $(8-38$ amino acids), each containing a macrolide stalling motif; when the macrolide-bound ribosome pauses, the attenuator, a stem and loop structure that encompasses the RBS, is disrupted, resulting in ribosomal binding and synthesis of the methyltransferase (Subramaniam et al. 2011; Arenz et al. 2014a,b). Although most erm genes are regulated by translation attenuation, a few genes (e.g., erm $(\mathrm{K})$ ) are regulated by transcription attenuation (Kwak et al. 1991; Choi et al. 1997) or through inducible transcription factors (Morris et al. 2005). Ketolide induction has been described for $\operatorname{erm}(\mathrm{C})$ and involves promotion of frameshifting in the $\operatorname{erm}(\mathrm{C})$ leader (ermCL) mRNA, leading to bypass of the ermCL stop codon, via rearrangement of the secondary mRNA structure, allowing expression of the downstream resistance gene (Gupta et al. 2013a).

There are two families of macrolide efflux pumps with regulation that is at least in part, transcriptionally mediated-mef, a major-facil- 
C. Fyfe et al.

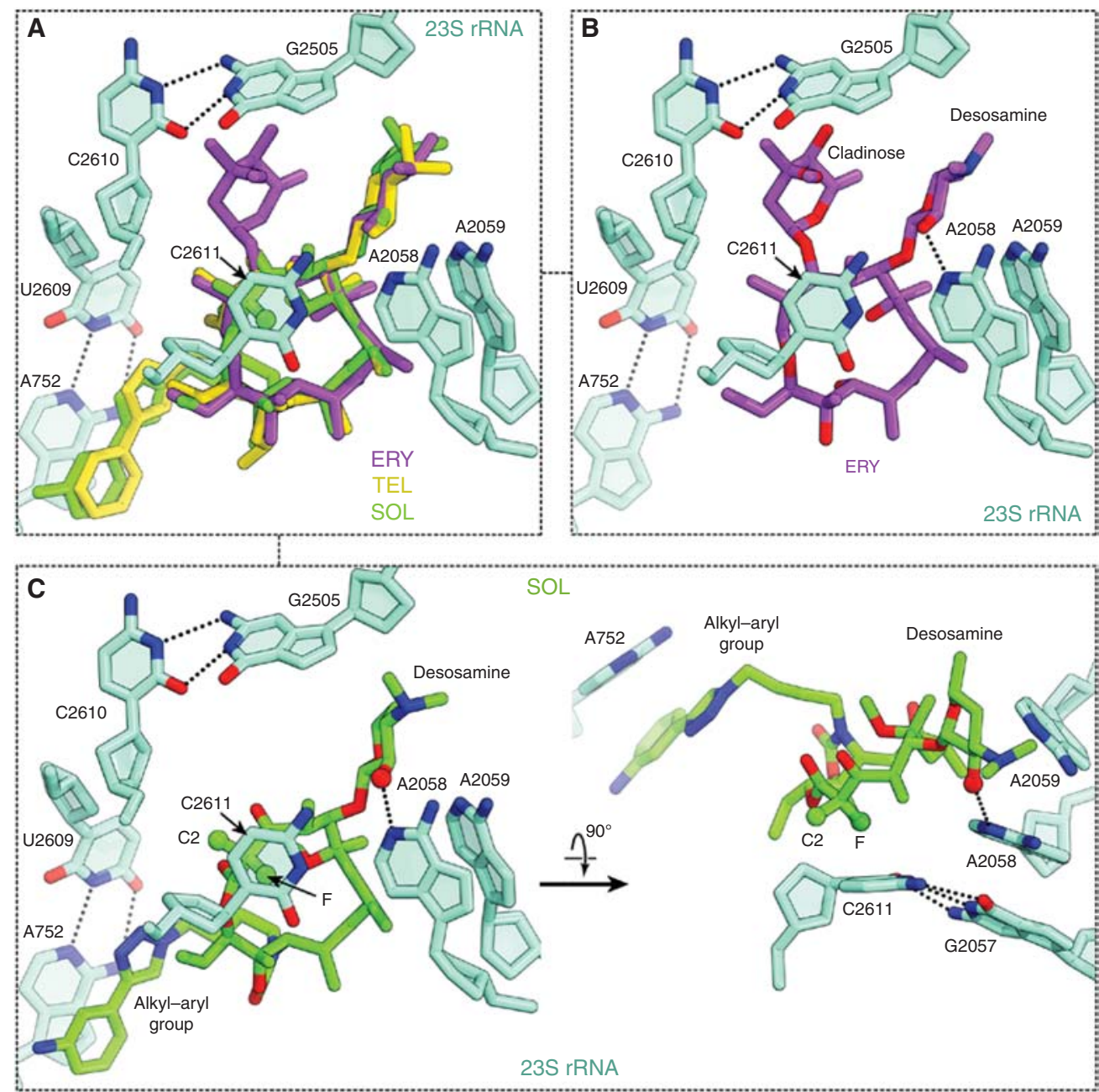

Figure 3. A model based on the crystal structure of the 70S Escherichia coli ribosome bound to erythromycin (PDB ID codes 3OFO, 3OFP, 3OFR, 3OFQ), telithromycin (PDB ID codes 3OAQ, 3OAR, 3OAS, 3OAT), and solithromycin (PDB ID code 4WWW) (Dunkle et al. 2010; Llano-Sotelo et al. 2010). (A) A comparison of the conformations of erythromycin (ERY, magenta), telithromycin (TEL, gold), and solithromycin (SOL, green) in their binding sites at the top of the nascent peptide exit tunnel (PET) comprised of 23S ribosomal RNA (rRNA). $23 \mathrm{~S}$ rRNA residues are marked, with nitrogen in dark blue and oxygen in red. Hydrogen bonds are indicated between residues by dotted lines, including between residues U2609 in domain V and A752 in domain II of $23 \mathrm{~S}$ rRNA. The alkyl-aryl arm of telithromycin and solithromycin is shown stacking with A752. (B) Erythromycinonly view. The key hydrogen bond between the $2^{\prime}$ hydroxyl of the desosamine and the N1 of A2058 is indicated. The exocyclic N6 amino group that is methylated by Erm methyltransferases is notable next to the N1 of A2058. (C) Solithromycin-only view. The left side of the figure displays solithromycin in the same conformation as macrolides in $A$ and $B$. The C2-F is visible through the ring of C2611, but a better view of its interaction with C2611 is displayed when the view is rotated by $90^{\circ}$, with the C2-F stacking with the hydrophobic side of C2611. C2611 is paired through three hydrogen bonds to G2057. 
itator-superfamily pump that confers resistance to most 14- and 15-membered macrolides (Leclercq and Courvalin 2002; Sutcliffe and Leclercq 2002; Chancey et al. 2011) and $m s r$, a member of the ATP-binding cassette (ABC) superfamily that generally confers resistance to 14- and 15membered macrolides and streptogramin B and low-level resistance to ketolides (Sutcliffe and Leclercq 2002; Chancey et al. 2011).

Intrinsic efflux pumps that are not specific to macrolides exist in different species. These pumps are often responsible for limiting macrolide spectrum in Gram-negative species and overexpression of multidrug efflux pumps is associated with clinically relevant drug resistance in both Gram-negative and Gram-positive species. Interested readers are referred to recent reviews (Costa et al. 2013; Blair et al. 2014; Delmar et al. 2014; Sun et al. 2014).

Mutations in 23S rRNA, L4, and/or L22 ribosomal proteins can confer macrolide resistance because the mutation is technically in the $23 \mathrm{~S}$ rRNA gene. In addition, macrolides can be inactivated by esterases or phosphotransferases (in public health pathogens and macrolide producers) or by glycosyltransferases (decribed in many strains of Streptomyces producing polyketides or polyether antibiotics; Micromonospora purpurea; Nocardia asteroides), deacylases ( $N$. asteroides), or formyl reductases (N. asteroides, Nocardia brasiliensis, Nocardia otitidiscaviarum) (Sutcliffe and Leclercq 2002; Roberts 2008; Shakya and Wright 2010; Morar et al. 2012). Many strains carry more than one macrolide resistance mechanism, sometimes on the same mobile element.

This review will focus on antimicrobial resistance mechanisms to macrolides primarily in public health pathogens. Recent reviews on the mechanisms of macrolide resistance are recommended (Leclercq and Courvalin 2002; Sutcliffe and Leclercq 2002; Franceschi et al. 2004; Depardieu et al. 2007; Roberts 2008; Kannan and Mankin 2011; Wilson 2014) as well as the website for macrolide-lincosamide-streptogramin resistances maintained by Marilyn Roberts (see faculty.washington.edu/marilynr). Based on the paper published in 1999 that set out to prevent duplicate genes being renamed when discovered in a new species or as part of a novel mobile element (Roberts et al. 1999), macrolide-resistant genes are considered in the same family if they have $\geq 80 \%$ amino acid identity from the original gene identified for that family.

\section{MACROLIDE MECHANISM OF ACTION}

All members of the macrolide class inhibit bacterial protein synthesis by binding to the $23 \mathrm{~S}$ rRNA in the large ribosomal subunit (50S) downstream from the peptidyltransferase center (PTC), the catalytic site for peptide bond formation (for overview of protein synthesis, see Arenz and Wilson 2016) (Wilson 2009, 2014; Dunkle et al. 2010; Kannan et al. 2014). Macrolides/ketolides bind at the entrance of the peptide exit tunnel (PET) just above the constriction formed by extended loops of ribosomal proteins L4 and L22 (Yusupov et al. 2001; Davydova et al. 2002; Hansen et al. 2002; Schlunzen et al. 2003; Tu et al. 2005; Dunkle et al. 2010), further restricting the effective diameter of the PET. The macrocyclic lactone and the C5 sugars overlap (Fig. 3A). The sugar at C5 (often desosamine) is positioned toward the PTC, and macrolides like tylosin that have a disaccharide at the C5 position, reach deeper into the PTC. The 2' hydroxyl of desosamine sugar at C5 makes a key hydrogen bond contact with the $\mathrm{N} 1$ atom of A2058 and modification at this position by either mutation or methylation of the N6 exocyclic amine results in macrolide resistance (see Fig. 3B) (Sutcliffe and Leclercq 2002; Franceschi et al. 2004; Tu et al. 2005; Dunkle et al. 2010). Other residues help define a local binding conformation for macrolides, including G2057 and C2611 that form a WatsonCrick base pair with each other and to which the hydrophobic face of the lactone ring is packed (seen best in Fig. 3C). For ketolides, telithromycin, and solithromycin, the extended alkyl-aryl arm of each drug is oriented down the tunnel and makes a stacking interaction with a base pair formed by A752 and U2609 in the 23S rRNA (Fig. 3A,C); these side chains align closely in the crystal structure of each drug complexed to E. coli 70 S ribosome, but are positioned differently from the crystal structures 
C. Fyfe et al.

of telithromycin complexed with either Deinococcus radiodurans or Haloarcula marismortui (Schlunzen et al. 2003; Tu et al. 2005; Dunkle et al. 2010; Llano-Sotelo et al. 2010), likely a result of the absence of the A752-U2609 base pair seen in most pathogenic bacteria. Solithromycin has an additional stacking interaction with the hydrophobic portion of C2611 via its C2-fluorine, thereby conferring eightfold better activity against S. pneumoniae constitutive erm(B) isolates than a corresponding structure with hydrogen at C2 (Fig. 3C) (Llano-Sotelo et al. 2010).

Until recently, macrolides were thought to inhibit protein synthesis by sterically blocking nascent peptides as they transversed the PET (Hansen et al. 2002; Voss et al. 2006). However, despite the constriction formed from L4 and L22 loops and bound macrolide, there is still room in the PET for nascent, unfolded peptides to successfully negotiate the tunnel ( $\mathrm{Tu}$ et al. 2005; Dunkle et al. 2010; Kannan et al. 2012). Further, genome-wide ribosome profiling analyses in E. coli have shown that ribosomes with bound erythromycin or telithromycin allow a compound-dependent subset of proteins to be synthesized, rather than act as general translation inhibitors (Kannan et al. 2012, 2014). Further work has shown that ribosomes bound with a macrolide or ketolide are impaired in the efficient catalysis of peptide bond formation and that this impairment is sequence- and context-specific (i.e., dependent on macrolide stalling motifs) (Arenz et al. 2014a; Kannan et al. 2014; Sothiselvam et al. 2014). If a macrolidestalling motif is encountered near the amino terminus of an ORF, then ribosomal stalling of a short nascent peptide likely leads to premature release of peptidyl-tRNA, consistent with early biochemical studies with erythromycin (Otaka and Kaji 1975; Menninger 1985; Tenson et al. 2003). However, macrolide stalling motifs can be hundreds of codons away from the start codon, resulting in the synthesis of large peptides and, for some proteins that have no translation arrest sequences, synthesis of full length proteins (Kannan et al. 2012). Translation arrest can occur because specific sequences (macrolide stalling motifs) of the nascent leader peptide in the ribosomal tunnel sense the ribo- some-bound antibiotic and, through interactions with it and with elements of the tunnel wall, induce conformational rearrangements that are communicated to the PTC so as to stop translation (Arenz et al. 2014a,b; Sothiselvam et al. 2014). Alternatively, macrolide- and peptide-dependent programmed translation arrest is also defined by the nature of the amino acid residues in the PTC (Kannan et al. 2014). Amazingly, the "nose" of the ribosome can sense small structural changes in the macrolide as well as discriminate a single amino acid difference in the nascent peptide (Gupta et al. 2016). Further, the discriminating properties of the PET allow for regulation of cis-located target gene expression, protein targeting and folding, and response to additional cellular factors (Ito et al. 2010; Kannan et al. 2014; Gupta et al. 2016).

Investigation into the mechanism by which ketolides induce erm(C) uncovered another mechanism of action of ketolides and macrolides - promotion of frameshifting (Gupta et al. 2013a). Intriguingly, the extent of reduction in translational fidelity is compound-dependent and is reliant on the antibiotic allosterically influencing the reading-frame maintenance in the 30S ribosomal subunit, some $90 \AA$ away from the macrolide/ketolide binding site in the 50S ribosomal subunit (Gupta et al. 2013a). Because $25 \%$ of the entire E. coli proteome continues to be synthesized in the presence of telithromycin (Kannan et al. 2012), production of aberrant cellular proteins may also be important to its antibacterial action.

\section{MACROLIDE-RESISTANT MECHANISMS}

\section{Ribosomal Modifications}

\section{S rRNA Mutations}

Mutants that are resistant to one or more of the $\mathrm{MLS}_{\mathrm{B}}$ antibiotics, because of base substitutions in either domain $\mathrm{V}$ or helix 35 in domain II of 23S rRNA or in ribosomal proteins L4 or L22, provide genetic evidence that these antibiotics interact with the ribosome (Figs. 3 and 4) (Vester and Douthwaite 2001; Sutcliffe and Leclercq 2002; Franceschi et al. 2004). Macrolides primarily interact with A2058 and A2059 of the 


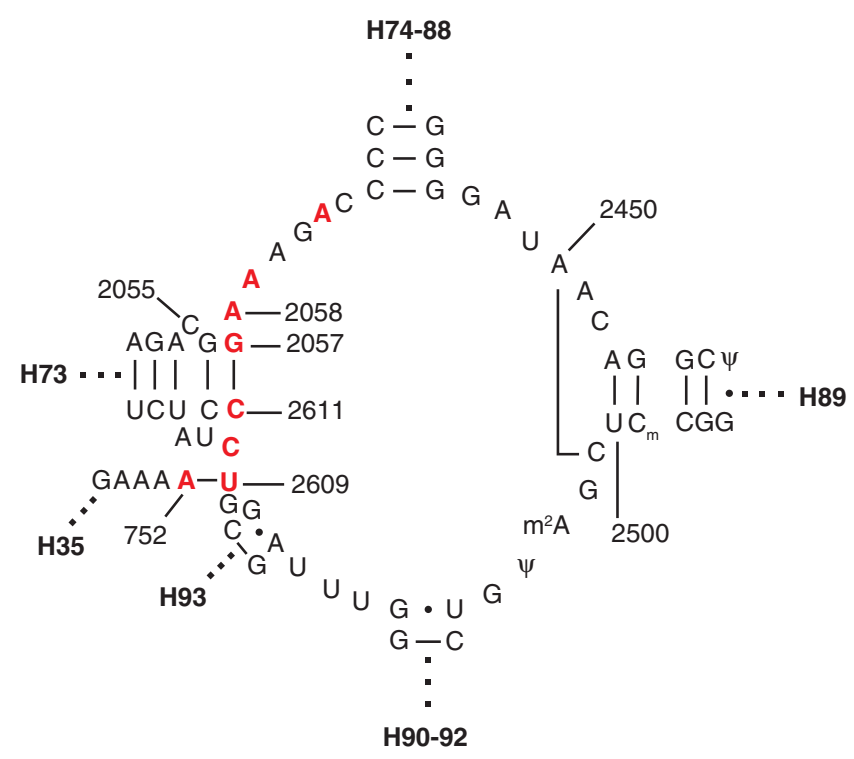

Figure 4. The secondary structure of the $3^{\prime}$ region of $23 \mathrm{~S}$ ribosomal RNA (rRNA) domain V. Nucleotides in red indicate mutations that can yield 14/15-membered macrolide, 16-membered macrolide, and/or ketolide resistance (see Schwarz et al. 2016 for mutations in this region that alter lincosamides, streptogramins, phenicols, and pleuromutilins). rRNA helices that stem from this region are designated with dotted lines. Residue A752 is in the hairpin 35 loop of domain II.

$23 \mathrm{~S}$ rRNA and mutations in these nucleotides have been found in many macrolide-resistant bacterial strains, generally in pathogens (Mycobacterium, Brachyspira, Helicobacter, Treponema) with just one or two copies of $r r l$, the gene that codes for 23S rRNA or, in pathogens with three or more rRNA genes, may develop during chronic treatment of macrolides (Table 1). However, mutations in these positions as well as at G2057 in combination with A2059, and at C2611, have been found in clinical isolates and laboratory mutants of $S$. pneumoniae (TaitKamradt et al. 2000a,b; Canu et al. 2002), at A2058 and C2611 in clinical isolates of Streptococcus pyogenes (Malbruny et al. 2002; Jalava et al. 2004), and at A2058, A2059, or both A2059 and G2160 in clinical isolates of H. influenzae (Peric et al. 2003). Consistently, mutations at A2058 and A2059 are the most frequently observed and have a strong phenotype in all species, generally conferring macrolide-lincosamide-streptogramin B-ketolide $\left(\mathrm{MLS}_{\mathrm{B}} \mathrm{K}\right)$ resistance in most isolates. A comprehensive listing of ribosomal $23 \mathrm{~S}$ rRNA mutations isolated in S. pneumoniae, S. pyogenes, and H. influenzae before 2005 has been assembled by Franceschi et al. (2004). Table 1 updates the base substitutions and extends the citings to other species.

With the increase in use of the macrolide azithromycin as a maintenance treatment for cystic fibrosis (CF) patients, there has been an increase in the levels of $\mathrm{MLS}_{\mathrm{B}}$-resistant Staphylococcus aureus isolated from CF patients. Six azithromycin- and erythromycin-resistant isolates of $S$. aureus from CF patients after treatment with azithromycin (Prunier et al. 2002), that did not carry resistance determinant erm or $m s r(\mathrm{~A})$ genes, were found to carry mutations A2058G, A2058T, or A2059G with copy numbers of mutant alleles ranging from three of five and four of five to four of six $\mathrm{rrl}$ genes (S. aureus can have five or six $r r l$ genes). A more recent characterization of $S$. aureus strains isolated from Czech CF patients showed high rates $(29 \%)$ of strains with ribosomal mutations conferring resistance to $\mathrm{MLS}_{\mathrm{B}}$ antibiotics with the majority in $23 \mathrm{~S}$ rRNA (23\%) (Tkadlec et al. 2015). 
C. Fyfe et al.

Table 1. Mutations in $23 \mathrm{~S}$ rRNA (E. coli numbering) conferring macrolide/ketolide resistance

\begin{tabular}{|c|c|c|c|c|}
\hline Nucleotide & Organism & Wild-type & Mutant & References \\
\hline \multirow[t]{2}{*}{752} & Mycoplasma genitalium & A & $\mathrm{C}$ & Jensen et al. 2014 \\
\hline & $\begin{array}{l}\text { Streptococcus } \\
\text { pneumoniae }\end{array}$ & A & Deletion & Canu et al. 2000 \\
\hline 754 & Escherichia coli & $\mathrm{U}$ & $\mathrm{A}$ & Xiong et al. 1999 \\
\hline 2038 & M. genitalium & $\mathrm{C}$ & $\mathrm{T}$ & Chrisment et al. 2012 \\
\hline \multirow[t]{4}{*}{2057} & E. coli & G & $\mathrm{A}$ & Ettayebi et al. 1985 \\
\hline & Mycoplasma fermentans & G & $\mathrm{A}$ & Pereyre et al. 2002 \\
\hline & Mycoplasma hominis & G & $\mathrm{A}$ & Pereyre et al. 2002 \\
\hline & Propionibacterium spp. & G & A & Ross et al. 1997 \\
\hline $2057+2032$ & E. coli & $\mathrm{G} / \mathrm{G}$ & $\mathrm{A} / \mathrm{A}$ & Douthwaite 1992 \\
\hline $2057+2032$ & Helicobacter pylori & $\mathrm{A} / \mathrm{G}$ & $\mathrm{G} / \mathrm{A}$ & Hulten et al. 1997 \\
\hline \multirow[t]{3}{*}{$2057+2059$} & S. pneumoniae & $\mathrm{G} / \mathrm{A}$ & $\mathrm{A} / \mathrm{C}$ & Fu et al. 2000 \\
\hline & S. pneumoniae & $\mathrm{G} / \mathrm{A}$ & $\mathrm{A} / \mathrm{G}$ & Farrell et al. 2004 \\
\hline & Streptococcus pyogenes & $\mathrm{G} / \mathrm{A}$ & $\mathrm{A} / \mathrm{G}$ & Doktor et al. 2001 \\
\hline $2058+2160$ & Haemophilus influenzae & $\mathrm{A} / \mathrm{G}$ & $\mathrm{G} / \mathrm{T}$ & Peric et al. 2003 \\
\hline $2058+2166$ & Streptococcus pyogenes & $\mathrm{A} / \mathrm{U}$ & $\mathrm{G} / \mathrm{C}$ & Farrell et al. 2006 \\
\hline $2058+2160$ & Haemophilus influenzae & $\mathrm{A} / \mathrm{G}$ & $\mathrm{G} / \mathrm{U}$ & Peric et al. 2003 \\
\hline $2059+2059$ & S. pneumoniae & $\mathrm{A} / \mathrm{A}$ & $\mathrm{G} / \mathrm{C}$ & Farrell et al. 2004 \\
\hline \multirow[t]{19}{*}{2058} & Brachyspira hyodysenteriae & A & $\mathrm{G}, \mathrm{T}$ & Karlsson et al. 1999 \\
\hline & E. coli & A & G & $\begin{array}{l}\text { Vester and Garrett 1987; Douthwaite } \\
1992\end{array}$ \\
\hline & E. coli & A & $\mathrm{T}$ & Sigmund et al. 1984 \\
\hline & H. influenzae & $\mathrm{A}$ & G & Clark et al. 2002 \\
\hline & H. pylori & A & C, G & $\begin{array}{l}\text { Stone et al. 1996; Hulten et al. 1997; } \\
\text { Occhialini et al. 1997; Versalovic } \\
\text { et al. 1997; Debets-Ossenkopp } \\
\text { et al. 1998; Wang and Taylor } 1998\end{array}$ \\
\hline & Moraxella catarrhalis & A & $\mathrm{T}$ & Saito et al. 2012; Iwata et al. 2015 \\
\hline & Mycobacterium abscessus & $\mathrm{A}$ & G & Wallace et al. 1996 \\
\hline & Mycobacterium avium & A & $\mathrm{C}, \mathrm{G}, \mathrm{T}$ & Nash and Inderlied 1995 \\
\hline & Mycobacterium chelonae & $\mathrm{A}$ & $\mathrm{C}, \mathrm{G}$ & Wallace et al. 1996 \\
\hline & Mycobacterium intracellulare & A & $\mathrm{C}, \mathrm{G}, \mathrm{T}$ & Meier et al. 1994 \\
\hline & Mycobacterium kansasii & A & $\mathrm{T}$ & Burman et al. 1998 \\
\hline & Mycobacterium smegmatis & $\mathrm{A}$ & G & Sander et al. 1997 \\
\hline & M. genitalium & A & $\mathrm{C}, \mathrm{G}$ & $\begin{array}{l}\text { Jensen et al. 2008; Ito et al. 2011; } \\
\text { Chrisment et al. 2012; Gesink et al. } \\
\text { 2012; Twin et al. 2012; Touati et al. } \\
\text { 2014; Bissessor et al. } 2015\end{array}$ \\
\hline & M. hominis & $\mathrm{A}$ & G & Pereyre et al. 2002 \\
\hline & Mycoplasma pneumoniae & A & $\mathrm{C}, \mathrm{G}, \mathrm{T}$ & $\begin{array}{l}\text { Lucier et al. 1995; Matsuoka et al. } \\
\text { 2004; Liu et al. 2009b; Peuchant } \\
\text { et al. 2009; Xin et al. 2009; Cao } \\
\text { et al. 2010; Kawai et al. 2013; Ye } \\
\text { et al. 2013; Zhou et al. } 2015\end{array}$ \\
\hline & Propionibacterium spp. & A & G & Ross et al. 1997 \\
\hline & Staphylococcus aureus & A & $\mathrm{G}, \mathrm{T}$ & Prunier et al. 2002 \\
\hline & S. pneumoniae & A & $\mathrm{G}, \mathrm{T}$ & $\begin{array}{l}\text { Tait-Kamradt et al. 2000a,b; Canu } \\
\text { et al. 2002; Farrell et al. } 2004\end{array}$ \\
\hline & S. pyogenes & A & G & Jalava et al. 2004 \\
\hline
\end{tabular}

Continued 
Resistance to Macrolide Antibiotics in Public Health Pathogens

Table 1. Continued

\begin{tabular}{|c|c|c|c|c|}
\hline Nucleotide & Organism & Wild-type & Mutant & References \\
\hline & Treponema pallidum & $\mathrm{A}$ & G & Stamm and Bergen 2000 \\
\hline \multirow[t]{11}{*}{2059} & H. influenzae & A & G & Clark et al. 2002 \\
\hline & H. pylori & A & $\mathrm{C}, \mathrm{G}, \mathrm{T}$ & $\begin{array}{l}\text { Hulten et al. 1997; Occhialini et al. } \\
\text { 1997; Versalovic et al. 1997; } \\
\text { Debets-Ossenkopp et al. 1998; } \\
\text { Wang and Taylor } 1998\end{array}$ \\
\hline & Propionibacterium spp. & A & G & Ross et al. 1997 \\
\hline & M. abscessus & A & C, G & Wallace et al. 1996 \\
\hline & M. avium & A & $\mathrm{C}$ & Nash and Inderlied 1995 \\
\hline & M. chelonae & $\mathrm{A}$ & G & Wallace et al. 1996 \\
\hline & M. intracellulare & A & $\mathrm{C}$ & Meier et al. 1994 \\
\hline & M. genitalium & A & C, G & $\begin{array}{l}\text { Jensen et al. 2008; Ito et al. 2011; } \\
\text { Chrisment et al. 2012; Gesink et al. } \\
\text { 2012; Twin et al. 2012; Touati et al. } \\
\text { 2014; Bissessor et al. } 2015\end{array}$ \\
\hline & M. pneumoniae & A & G & $\begin{array}{l}\text { Matsuoka et al. 2004; Peuchant et al. } \\
\text { 2009; Xin et al. 2009; Cao et al. } \\
\text { 2010; Kawai et al. } 2013\end{array}$ \\
\hline & S. aureus & A & G & Prunier et al. 2002 \\
\hline & S. pneumoniae & A & $C, G$ & $\begin{array}{l}\text { Tait-Kamradt et al. 2000a; Farrell } \\
\text { et al. 2004; Rantala et al. } 2005\end{array}$ \\
\hline \multirow[t]{3}{*}{2062} & M. genitalium & $\mathrm{A}$ & $\mathrm{T}$ & Chrisment et al. 2012 \\
\hline & M. pneumoniae & A & G & $\begin{array}{l}\text { Bebear and Pereyre 2005; Peuchant } \\
\text { et al. } 2009\end{array}$ \\
\hline & S. pneumoniae & A & $\mathrm{C}$ & Depardieu and Courvalin 2001 \\
\hline 2098 & H. pylori & $\mathrm{T}$ & $\mathrm{C}$ & Kim et al. 2008; Rimbara et al. $2008^{\mathrm{a}}$ \\
\hline 2160 & H. influenzae & G & $\mathrm{U}$ & Peric et al. 2003 \\
\hline $2160-2162$ & H. influenzae & GGA & UAU & Peric et al. 2003 \\
\hline 2164 & H. influenzae & $\mathrm{C}$ & G & Peric et al. 2003 \\
\hline 2185 & M. genitalium & $\mathrm{T}$ & G & Shimada et al. 2011 \\
\hline 2609 & E. coli & $\mathrm{U}$ & $\mathrm{C}$ & Garza-Ramos et al. 2001 \\
\hline 2610 & M. hominis & $\mathrm{C}$ & $\mathrm{U}$ & Pereyre et al. 2002 \\
\hline \multirow[t]{9}{*}{2611} & Chlamydia trachomatis & $\mathrm{C}$ & $\mathrm{T}$ & Misyurina et al. 2004 \\
\hline & E. coli & $\mathrm{C}$ & $\mathrm{T}$ & Vannuffel et al. 1992 \\
\hline & H. pylori & $\mathrm{C}$ & A & Rimbara et al. 2008 \\
\hline & M. hominis & $\mathrm{C}$ & $\mathrm{T}$ & Pereyre et al. 2002 \\
\hline & M. pneumoniae & $\mathrm{C}$ & $A, G$ & $\begin{array}{l}\text { Matsuoka et al. 2004; Peuchant et al. } \\
\text { 2009; Kawai et al. 2013; Ye et al. } \\
2013\end{array}$ \\
\hline & Neisseria gonorrhoeae & $\mathrm{C}$ & & $\mathrm{Ng}$ et al. 2002 \\
\hline & S. pneumoniae & $\mathrm{C}$ & $A, G$ & $\begin{array}{l}\text { Tait-Kamradt et al. 2000b; } \\
\text { Pihlajamaki et al. 2002; Farrell } \\
\text { et al. 2003; Farrell and } \\
\text { Felmingham } 2004\end{array}$ \\
\hline & S. pneumoniae & $\mathrm{C}$ & $\mathrm{T}$ & Rantala et al. 2005 \\
\hline & S. pyogenes & $\mathrm{C}$ & $\mathrm{T}$ & Malbruny et al. 2002 \\
\hline
\end{tabular}

Not all mutations have been shown to solely cause macrolide/ketolide resistance; base substitutions can occur in the background of ribosomal protein changes.

${ }^{\mathrm{a}}$ This mutation was not required for clarithromycin resistance in the background of C2611A mutation in (Rimbara et al. 2008), 
C. Fyfe et al.

An analysis of 14 of 217 erythromycin-resistant clinical S. pneumoniae isolates collected in Finland in 2002 (Rantala et al. 2005) characterized by polymerase chain reaction (PCR) did not harbor an efflux mechanism, mef(E) or mef(A), or a target modification mechanism, erm(B) or erm(A) subclass erm(TR), but did have previously identified A2059G mutations in one or more $23 \mathrm{~S}$ rRNA genes. As had been shown previously, erythromycin minimum inhibitory concentrations (MICs) increased with an increasing number of $\mathrm{rrl}$ alleles containing A2059G (Tait-Kamradt et al. 2000a), whereas a C2611T mutation was present in all four alleles (Rantala et al. 2005). In Helicobacter pylori, only one of the two alleles needs to contain a $23 \mathrm{~S}$ rRNA mutation to result in macrolide resistance (Hulten et al. 1997). Mutations in $r r l$ are also found in combination with mutations in genes encoding L4 or L22 in many species.

\section{Ribosomal Protein Mutations}

Mutations in genes encoding ribosomal proteins L4 and L22 in laboratory isolates of $E$. coli and clinical isolates of $S$. pneumoniae can confer erythromycin resistance and reduced telithromycin susceptibility (Tait-Kamradt et al. 2000a; Pihlajamaki et al. 2002). In addition to the changes detailed below, a list of L4 and L22 mutations can be found in Franceschi et al. (2004).

Changes within a highly conserved sequence of S. pneumoniae L4 ( ${ }_{3}$ KPWRQKGTG $\mathrm{RAR}_{74}$ ) can result in decreased susceptibility to macrolides or ketolides (a 500-fold increase to a telithromycin MIC of $3.12 \mu \mathrm{g} / \mathrm{mL}$ for one variation) as well as alter fitness or confer temperature sensitivity of growth (Tait-Kamradt et al. 2000a,b; Farrell et al. 2004). This sequence forms the loop that extends into the PET. Mutations in L4 that have been identified within the conserved sequence encode ${ }_{68} \mathrm{E}_{69},{ }_{68} \mathrm{KEG}_{69}$, or ${ }_{68} \mathrm{GQK}_{69}$ insertions; $\mathrm{T}_{94} \mathrm{I}, \mathrm{E}_{30} \mathrm{~K}, \mathrm{~S}_{20} \mathrm{~N}, \mathrm{G}_{71} \mathrm{R}$, $\mathrm{I}_{78} \mathrm{~V}, \mathrm{~K}_{68} \mathrm{~S}, \mathrm{~K}_{68} \mathrm{Q},{ }_{69} \mathrm{VP}_{70},{ }_{69} \mathrm{TPS}_{71}$, or $\mathrm{V}_{88} \mathrm{I}$ substitutions; ${ }_{69} \mathrm{GTGR}_{72}$ or ${ }_{64} \mathrm{P}-\mathrm{Q}_{67}$ deletions. In $S$. pyogenes isolates from children treated with azithromycin, amino acid variations in L4 ${ }_{64} \mathrm{WR}_{65}$ or ${ }_{69} \mathrm{TG}_{70}$ deletion; insertion of $\mathrm{RA}$ after position $73,{ }_{73} \mathrm{RA}$ ) were uncovered (Bingen et al. 2002). In $H$. influenzae, L4 amino acid variations (insertion ${ }_{65} \mathrm{GT}, \mathrm{K}_{61} \mathrm{Q}, \mathrm{T}_{64} \mathrm{~K}, \mathrm{G}_{65} \mathrm{D}$; deletion ${ }_{65} \mathrm{GR}, \mathrm{G}_{53} \mathrm{~A}$; deletion of ${ }_{66} \mathrm{RA}, \mathrm{A}_{69} \mathrm{~S}$, $\left.\mathrm{T}_{82} \mathrm{I}, \mathrm{D}_{94} \mathrm{E}, \mathrm{D}_{139} \mathrm{G}\right)$, some outside the loop region, could provide high-level resistance of up to $128 \mu \mathrm{g} / \mathrm{mL}$ for 14 - and 15 -membered macrolides (Clark et al. 2002; Peric et al. 2003). $S$. aureus isolates with L4 amino acid changes $\mathrm{R}_{168} \mathrm{~S}, \mathrm{G}_{69} \mathrm{~A}$, and $\mathrm{T}_{70} \mathrm{P}$ have been described in CF patients (Prunier et al. 2005). Amino acid variations in $\mathrm{L} 4$ from $M$. genitalium $\left(\mathrm{N}_{21} \mathrm{~K}\right.$, $\mathrm{H}_{69} \mathrm{R}, \mathrm{V}_{84} \mathrm{G}, \mathrm{E}_{128} \mathrm{G}, \mathrm{P}_{81} \mathrm{~S}, \mathrm{Y}_{135} \mathrm{P}, \mathrm{N}_{172} \mathrm{~S}, \mathrm{~N}_{172} \mathrm{~S}$, $\mathrm{A}_{114} \mathrm{~V}, \mathrm{~A}_{116} \mathrm{~V}, \mathrm{~A}_{114} \mathrm{~S}, \mathrm{R}_{45} \mathrm{~K}$ ) were found encoded in DNA from the urine of men with nongonococcal urethritis (Shimada et al. 2011), and in the chromosomal DNA isolated from a collection of M. genitalium isolates (Jensen et al. 2014). The $\mathrm{L} 4 \mathrm{~A}_{209} \mathrm{~T}$ variation was found in chromosomal DNA of Mycoplasma pneumoniae isolates from patients (Cao et al. 2010).

Mutations encoding amino acid changes in the carboxy-terminal region of ribosomal protein L22 (e.g., $\mathrm{G}_{95} \mathrm{D}, \mathrm{P}_{99} \mathrm{Q}, \mathrm{A}_{93} \mathrm{E}, \mathrm{P}_{91} \mathrm{~S}, \mathrm{G}_{83} \mathrm{E}$, $\mathrm{A}_{101} \mathrm{P},{ }_{109} \mathrm{RTAHIT}_{114}$ tandem duplication) resulted in decreased susceptibility to macrolides and ketolides, although the MICs were not greater than $1 \mu \mathrm{g} / \mathrm{mL}$ in S. pneumoniae (Canu et al. 2002; Farrell et al. 2003). A mutation encoding $\mathrm{K}_{94} \mathrm{Q}$ along with a large deletion in the $\operatorname{erm}(\mathrm{B})$ upstream region was selected by telithromycin in a $S$. pneumoniae isolate with erm(B) (Walsh et al. 2003). In H. influenzae clinical isolates, MICs increased 4- to 16-fold with insertions or deletions in $\mathrm{L} 22\left(\mathrm{G}_{91} \mathrm{D}\right.$; insertions of ${ }_{77}$ DEGPSM, ${ }_{88}$ RAKG, ${ }_{91} \mathrm{KG},{ }_{91} \mathrm{RAG}$, or ${ }_{91} \mathrm{RADR}$; deletions of ${ }_{81} \mathrm{~S},{ }_{82} \mathrm{M},{ }_{91} \mathrm{KG},{ }_{95} \mathrm{R}$, ${ }_{95} \mathrm{RI}$, or ${ }_{96} \mathrm{ILKR}$ ) (Clark et al. 2002; Peric et al. 2003). A deletion of three amino acids in L22 associated with an A2058 mutation has also been reported in a $S$. aureus isolate from CF patients (Prunier et al. 2002). Amino acid changes in L22 from $M$. genitalium $\left(\mathrm{A}_{43} \mathrm{~V}\right.$, $\mathrm{G}_{93} \mathrm{E}+\mathrm{D}_{109} \mathrm{E}, \quad \mathrm{S}_{81} \mathrm{~T}, \quad \mathrm{~S}_{81} \mathrm{~N}, \quad \mathrm{M}_{82} \mathrm{~L}, \quad \mathrm{~N}_{112} \mathrm{D}$, $\mathrm{R}_{114} \mathrm{~K}, \mathrm{E}_{123} \mathrm{~K}$ ) were found in men with nongonococcal urethritis (Ito et al. 2011; Shimada et al. 2011). In M. pneumoniae, all 14-membered macrolide-resistant isolates harbored a $\mathrm{T}_{508} \mathrm{C}$ mutation in L22 and, for most, either an 
A2058G or A2059G mutation in 23S rRNA (Cao et al. 2010; Jensen et al. 2014).

Resistance to telithromycin in S. pneumoniae significantly increases when 23S rRNA methylation/mutations are combined with ribosomal protein mutations. For example, a combination of a truncated leader peptide leading to constitutive synthesis of erm(B) conferred a telithromycin MIC of $16 \mu \mathrm{g} / \mathrm{mL}$ (Wolter et al. 2008a), whereas clinical isolates with both a constitutive $\operatorname{erm}(\mathrm{B})$ and a ${ }_{69} \mathrm{GTG}_{71}$ to TPS substitution in L4 (Wolter et al. 2007) or a combined A2058T mutation and a three-amino acid deletion in L22 (Faccone et al. 2005), provided high-level telithromycin resistance ( $\geq 256 \mu \mathrm{g} / \mathrm{mL}$ ). A patient with a S. pneumoniae isolate harboring an A2058G mutation in 23S rRNA and an RTAHIT insertion in L22 between amino acid $\mathrm{T}_{108}$ and $\mathrm{V}_{109}$ resulted in a telithromycin MIC of $16 \mu \mathrm{g} / \mathrm{mL}$ (Perez-Trallero et al. 2003). In addition, a telithromycin-resistant isolate with a MIC of $8 \mu \mathrm{g} / \mathrm{mL}$ was found to contain an $\operatorname{erm}(\mathrm{B})$ gene, an $\mathrm{S}_{20} \mathrm{~N}$ variation in L4, and a number of mutations in $23 \mathrm{~S}$ rRNA (Reinert et al. 2005). A highly resistant laboratory-generated S. pneumoniae strain (MIC, $32 \mu \mathrm{g} / \mathrm{ml}$ ) contained a 210-bp deletion in the $\operatorname{erm}(\mathrm{B})$ upstream region together with a $\mathrm{K}_{94} \mathrm{Q}$ mutation in L22 (Walsh et al. 2003).

\section{erm Genes}

A major and widespread mechanism of resistance to the macrolide class of antibiotics is mediated by erm genes that encode rRNA methyltransferases that add one or two methyl groups to the exocyclic amino group of A2058 (Figs. 3 and 4) located in the PET of 23S rRNA (Horinouchi and Weisblum 1980; Weisblum 1995a). In addition to conferring resistance to 14-, 15-, and 16-membered macrolides and ketolides, resistance to two other classes of antibiotics, lincosamides and streptogramin B, is imparted, giving the host a $\mathrm{MLS}_{\mathrm{B}} \mathrm{K}$ phenotype (Sutcliffe and Leclercq 2002; Roberts 2008; Schwarz et al. 2016).

As of January 2016, $38 \mathrm{erm}$ genes have been reported (see faculty.washington.edu/ marilynr). Among the erm genes, the most commonly carried is erm(B) (36 genera), followed by erm(C) (32 genera), erm(F) (25 genera), erm(X) (15 genera), erm(V) (11 genera), $\operatorname{erm}(\mathrm{A})$ (nine genera), $\operatorname{erm}(\mathrm{G})$ and $\operatorname{erm}(\mathrm{E})$ (seven genera each), $\operatorname{erm}(\mathrm{Q})$ (six genera), $\operatorname{erm}(\mathrm{T})$ (four genera), erm(42) (three genera), erm(D) and $\operatorname{erm}(\mathrm{R})$ (two genera each). The remaining 25 $\mathrm{erm}$ genes are found in a single genus. Sixteen $(46 \%)$ of the erm genes $(\operatorname{erm}(\mathrm{H}), \operatorname{erm}(\mathrm{I})$, $\operatorname{erm}(\mathrm{N}), \operatorname{erm}(\mathrm{O}), \operatorname{erm}(\mathrm{R}), \operatorname{erm}(\mathrm{S}), \operatorname{erm}(\mathrm{U})$, $\operatorname{erm}(\mathrm{W}), \operatorname{erm}(\mathrm{Z}), \operatorname{erm}(30), \operatorname{erm}(31), \operatorname{erm}(32)$, erm(34), erm(36), erm(37), erm(38), erm(39), erm(40), erm(41), and erm(46)) are unique to environmental bacteria, defined as those species and genera that are primarily found outside of humans and animals.

\section{Inducible or Constitutive $M L S_{B}$ Phenotype}

Depending on the nature of leader sequences upstream of the translational start site, erm genes are either inducible by antibiotics or constitutively expressed; examples include erm(A) (Murphy 1985), erm(B) (Min et al. 2008), erm(C) (Gryczan et al. 1980; Horinouchi and Weisblum 1980; Weisblum 1995b), and erm(D) (Hue and Bechhofer 1992). For inducible erm genes, there are leader sequences upstream of the translational start site that form at least two stem and loop structures, one of which sequesters the ribosomal start site for the resistance gene, and the other upstream stem-loop structure that overlaps ORFs for one $(\operatorname{erm}(\mathrm{C})$, $\operatorname{erm}(\mathrm{B}), \operatorname{erm}(\mathrm{D}))$ or two (erm(A)) short peptides. Thus, in the absence of an inducing antibiotic, the upstream leader sequence and attending peptide is synthesized, but there is no synthesis of the erm gene because of sequestration of its ribosome-binding site. In the macrolide-bound ribosome, a macrolide-stalling motif in the nascent leader peptide is encountered and translation is stalled. The stalled ribosome allows an alternative messenger RNA (mRNA) secondary structure to form, such that the ribosome-binding site for the erm gene is exposed and available for translation by a ribosome not bound by erythromycin (Min et al. 2008; Arenz et al. 2014b). The programmed arrest of translation is both inducer (small molecule)- and 
C. Fyfe et al.

leader peptide-specific (Mayford and Weisblum 1990; Vazquez-Laslop et al. 2011; Kannan et al. 2014).

The high degree of variability among the regulatory leader regions of the mRNA transcripts for the different classes of erm genes, despite the highly conserved nature of the genes themselves, allows for a variety of phenotypes pertaining to induction by particular antibiotics (Subramaniam et al. 2011). Although most erm genes are induced by the 14- or 15-membered macrolides and not by 16-membered macrolides or ketolides, exceptions have been noted. The erm (B) subgroup erm (AMR) from a clinical strain of Enterococcus faecalis (Oh et al. 1998), erm(S) subgroup erm(SF) (Kelemen et al. 1994), and $\operatorname{erm}(\mathrm{V})$ subgroup erm(SV) (Fujisawa and Weisblum 1981) in 16-membered macrolideproducing Streptomyces spp. have been shown to be induced by tylosin and, in the latter, other 16-membered macrolides as well (Kamimiya and Weisblum 1997). Inducible resistance in Streptomyces spp. is the most diverse, with induction by lincomycin and streptogramin B in corresponding producers resulting in $\mathrm{N}^{6}$ dimethylation of $23 \mathrm{~S}$ rRNA and a $\mathrm{MLS}_{\mathrm{B}}$-resistant phenotype (Fujisawa and Weisblum 1981).

The length of the leader peptide can vary. The $\operatorname{Erm}(\mathrm{C})$ leader peptide (ErmCL) is $19 \mathrm{ami}$ no acids, with amino acids IFVI (I6-I9) constituting an important macrolide-stalling motif that triggers ribosome pausing. Cryoelectron microscopy (cryo-EM) of the erythromycin-dependent ErmCL-stalled ribosome complex (SRC) (Arenz et al. 2014b) revealed the path of the ErmCL nascent polypeptide chain, its contact with erythromycin, and its interactions with 23S rRNA nucleotides U2506, U2586, and A2062 within the ribosomal tunnel. Interactions of ErmCL amino acids V8 and F7 with U2506 and I6 with U2586 are consistent with experiments that show that mutations in the conserved I6-I9 motif severely reduce ribosome stalling (Vazquez-Laslop et al. 2008; Johansson et al. 2014). An interaction of the amino terminus (minimally I3) of ErmCL with A2062 stabilizes an unusual conformation such that this nucleotide is forced to lie flat against the tunnel wall instead of protruding into the tunnel lu- men, thereby allowing an interaction with A2503, consistent with the findings that mutations A2062U/C or A2503G dramatically alleviate ErmCL stalling (Vazquez-Laslop et al. 2008, 2010). In addition, ErmCL was observed to directly interact with the cladinose sugar of erythromycin, providing a structural explanation for how the nascent chain monitors the presence of erythromycin in PET. In the ErmCL-SRC, the PTC is remodeled because of interactions of the ErmCL nascent chain with U2586, U2506, and A2062, promoting a flipped conformation of U2585, which makes it unfavorable for the A-tRNA to fully accommodate, leading to dissociation and translation arrest (Arenz et al. 2014b). Previous crystallographic studies have shown that accommodation of the CCA-end of the A-site tRNA requires movement of nucleotides U2584 and U2585 (Schmeing et al. 2005; Simonovic and Steitz 2009).

Although ketolides lack the C3 cladinose and do not induce erm $(\mathrm{C})$ by the mechanism described above, they can promote its expression by inducing ribosomal frame-shifting errors within the erm $(\mathrm{C}$ ) leader ORF (Gupta et al. 2013a). Telithromycin induces a (-1) frameshift within a string of four adenine residues in the last two sense codons of ermCL, resulting in a read-through of the stop codon and unmasking of the erm (C) start codon because of the subsequent change in secondary mRNA structure. When other macrolides were tested on a model leader construct, it was found that frameshifting was also an intrinsic property (although to different degrees) of 14-membered macrolides as well as other ketolides.

In contrast to ErmCL, the ErmBL is 36 amino acids in length and erm(B) is induced by a wider range of 14- and 15-membered macrolides, including those that lack the C3 cladinose or have modifications of this sugar (Arenz et al. 2014a). Cryo-EM of ErmBL-SRC with erythromycin shows that nascent ErmBL travels a unique path in the PET and does not come into contact with the antibiotic, thereby defining a paradigm distinctly different than the one used for erm (C) induction (Arenz et al. 2014b). Stalling occurs after 10 amino acids have been polymerized and cryo-EM of the ErmBL-SRC 
shows that the P-site and the A-site are filled with the ErmBL-tRNA and the Lys-tRNA $\left(\mathrm{K}_{11}\right)$, respectively (Min et al. 2008; VazquezLaslop et al. 2010). No further peptide bond formation occurs because interactions of amino acids ${ }_{9} \mathrm{VD}_{10}$ and $\mathrm{R}_{7}$ with U2585 and U2586, respectively, stabilize $\mathrm{U} 2585$ in a position that precludes Lys-tRNA from being properly accommodated in the A-site. Notably missing in the ErmBL-SRC was any interaction of the nascent peptide with A2062 that was so critical for ErmCL-mediated ribosome stalling.

Gene regulation by nascent-peptide-dependent ribosome stalling expands beyond antibiotic resistance genes. Other examples in bacteria include translation arrest at the secM ORF activating the expression of $\sec A$ (Nakatogawa and Ito 2002; Bhushan et al. 2011) and ribosome stalling of the tnaC ORF regulating the expression of the tryptophanase operon (Gong and Yanofsky 2002; Seidelt et al. 2009).

The erm (D) subclass erm $(\mathrm{K})$ is regulated by both transcription and translation attenuation (Kwak et al. 1991; Choi et al. 1997), whereas erm(37) in Mycobacterium tuberculosis (Buriankova et al. 2004) has been shown to be activated by the erythromycin-inducible transcription activator WhiB7 (Morris et al. 2005). The erm(41) gene intrinsic in Mycobacterium abscessus and M. bolletii has been shown to be inducible by macrolides and ketolides; however, sequence analysis of the upstream region does not provide compelling evidence for regulation of this gene by either transcription or translation attenuation or by the inducible transcription factor WhiB (Nash et al. 2009).

Constitutive $\mathrm{MLS}_{\mathrm{B}}$ resistance can be conferred by a variety of mutations in the leader sequence (Sutcliffe and Leclercq 2002; Subramaniam et al. 2011), and includes deletions of the entire attenuator region for $\operatorname{erm}(\mathrm{C})$ in clinical isolates of $S$. epidermidis and S. aureus (Lampson and Parisi 1986) and for erm(B) in E. faecalis, S. agalactiae, and S. pneumoniae (Martin et al. 1987; Rosato et al. 1999; Wolter et al. 2008b) as well as tandem duplications in the attenuator of $\operatorname{erm}(\mathrm{C})$ of $\mathrm{S}$. aureus and S. equorum (Oliveira et al. 1993; Lodder et al. 1997), which either destabilize the hairpin structure sequestering the initiation sequences for the methyltransferase or duplicate the initiation sequences, leaving one unsequestered and available for translation. Notably, constitutive $\mathrm{erm}(\mathrm{B})$-containing pneumococcal isolates with a higher percentage of $23 \mathrm{~S}$ rRNA methylation were telithromycin-resistant (Douthwaite et al. 2005; Wolter et al. 2008a).

Clindamycin and 16-membered macrolides with more than an amino sugar at C5 do not induce erm expression in most species. This is now understood because both clindamycin and 16-membered macrolides directly interact with the PTC, inhibiting peptide bond synthesis; thus, is it unlikely that the synthesis of nascent peptide longer than a few amino acids could be synthesized, too short for the ribosome to sense or the nascent peptide to interact with the antibiotic (Tenson et al. 2003). Clinical isolates of $S$. pyogenes or $S$. agalactiae with variations in the leader sequence, including point mutations, insertions, deletions, and duplications, were shown to be resistant to both erythromycin and clindamycin, showing that constitutive resistance yields an $\mathrm{MLS}_{\mathrm{B}}$ phenotype (Culebras et al. 2005; Doktor and Shortridge 2005). In this study, three isolates with a 44-base duplication/insertion corresponding to bases 188 to 231, duplicating the erm (A) ribosomal binding site and start site, and one isolate with a 68-bp deletion of the entire leader peptide 2 region, were also resistant to the ketolide telithromycin.

Why are most erm genes inducible rather than constitutively expressed? Ribosome methylation at A2058 exerts a fitness cost because of the change in the ribosome's ability to sense/ respond to nascent peptides, thereby changing the expression of a number of cellular polypeptides (Ramu et al. 2009; Gupta et al. 2013b; Wilson 2014). Thus, deregulation of translation may well explain why bacteria prefer to retain the ability to become conditionally resistant.

\section{cis-Acting Peptides}

Translation of a pentapeptide encoded in E. coli $23 \mathrm{~S}$ rRNA can cause macrolides to dissociate from the ribosome, thereby conferring macrolide resistance (Tenson et al. 1996). Other cis- 


\section{Fyfe et al.}

acting peptides (resistance conferred only to a ribosome on which the peptide is synthesized) have been identified using a random-library approach, providing a consensus sequence, fMet-(bulky/hydrophobic)-(Leu/Ile)-(hydrophobic)-Val for erythromycin resistance; other consensus peptides specific for different macrolides (e.g., oleandomycin, ketolides, 15-membered macrolides) were also identified, consistent with the ability of the PET to distinguish small changes in antibiotic/nascent peptide interactions (Tenson et al. 1997; Vimberg et al. 2004). When key amino acids are synthesized in specific short peptides, the affinity of the macrolide/ketolide for its binding site is weakened, but removal of the antibiotic from the ribosome is most likely when the pentapeptide is removed from the peptidyl-tRNA by class I release factor (Lovmar et al. 2006).

\section{RIm Methyltransferases}

The importance of modifications to $23 \mathrm{~S} \mathrm{rRNA}$ is not completely understood. However, for tylosin producer Streptomyces fradiae, monomethylation of G748 and A2058 by rRNA methyltransferase $\mathrm{RlmA}^{\mathrm{II}}$ and $\operatorname{Erm}(\mathrm{N})$, respectively, is needed for self-preservation (Liu and Douthwaite 2002b; Takaya et al. 2013). Certain Grampositive bacteria like $S$. pneumoniae have an intrinsic chromosomal $r \operatorname{lm} A^{I I}$ gene (Liu and Douthwaite 2002a). Molecular modeling shows that the methyl group of G748 stabilizes the binding of telithromycin to the ribosome by moving the alkyl-aryl arm of telithromycin toward the aromatic rings of A752 in helix 35 (Fig. 3 shows the positions of A752 and A2058) (Takaya et al. 2013). Mutations in $r \operatorname{lm} A^{I I}$ preventing methylation of G748 in S. pneumoniae isolates that also harbor a constitutive erm(B) result in 16- to 32-fold greater resistance to telithromycin (Takaya et al. 2013). Just to keep things interesting, S. pneumoniae has another methyltransferase, RlmCD, which mediates a methyl transfer to both U747 (in helix 35) and U1939. Recent data have shown that RlmA ${ }^{\text {II }}$ prefers U747-methylated $23 \mathrm{~S}$ rRNA as a substrate; thus, when these two methyltransferases work sequentially, the binding of telithromycin to the ribosome is facilitated and, in their absence, telithromycin resistance occurs when there is dimethylation of A2058 by an erm methylase (Shoji et al. 2015).

\section{Acquired Macrolide Efflux Mechanisms}

Mef Family. Mef pumps are members of the major facilitator superfamily and have 12-transmembrane domains connected by hydrophilic loops, with both the amino and carboxyl termini located in the cytoplasm (Paulsen et al. 1996; Pao et al. 1998). They are antiporters with a binding site for macrolide antibiotics and have a rocker-switch type of movement, in which conformational changes in the protein are elicited to efflux a macrolide in exchange for a proton (Law et al. 2008). The mef genes are largely found among Gram-positive bacteria, but have also been reported in Gram-negative species (see faculty.washington.edu/marilynr; Ojo et al. 2004). The two major subclasses, mef(A) (Clancy et al. 1996), first identified in S. pyogenes isolates, and mef(E) (Tait-Kamradt et al. 1997), initially identified in S. pneumoniae, were characterized as providing resistance to 14- and 15 -membered macrolides but not 16-membered macrolides, lincosamides, or streptogramin B, thereby affording the M (macrolide-resistant only) phenotype (distinguishable from the $\mathrm{MLS}_{\mathrm{B}}$ phenotype). Both pumps are collectively categorized as mef(A) because of their $>80 \%$ amino acid sequence identity (Roberts et al. 1999). However, the two genes are carried on distinct genetic elements; Tn1207.1, $\operatorname{Tn} 1207.3, \varphi 10394.4$, or $\varphi m 46.1$ for mef(A) (Santagati et al. 2000, 2003; Giovanetti et al. 2003; Varaldo et al. 2009) and a macrolide efflux genetic assembly (megacomplex and derivative transposons Tn2009 and Tn2010 for mef(E)) (Gay and Stephens 2001; Del Grosso et al. 2002, 2004, 2006; Varaldo et al. 2009). Interestingly, although the megacomplex does not carry a transposase or recombinase as in Tn1207.1, the related mef-family complexes carry an adjacent ATP-binding cassette (ABC)-type transporter gene with sequences encoding two fused nucleotide-binding domains but no membrane-spanning domains, known as mel or $m s r(D)$ (because of its similarity to the S. aureus 
$m s r(A)$ gene) (Gay and Stephens 2001; Del Grosso et al. 2002). The $m s r(\mathrm{D})$ gene is adjacent to and cotranscribed with $m e f(\mathrm{E})$ in the presence of inducers like erythromycin. The exact function of $\mathrm{Msr}(\mathrm{D})$ in streptococci has yet to be fully elucidated, but coexpression of $m s r(\mathrm{D})$ and $m e f(\mathrm{E})$ is required for high-level macrolide efflux in S. pneumoniae, and both proteins interact synergistically to increase macrolide resistance in E. coli (Ambrose et al. 2005; Nunez-Samudio and Chesneau 2013). In E. coli, a physical association of $\operatorname{Msr}(\mathrm{D})$ and $\operatorname{Mef}(\mathrm{E})$ was shown using a mef(E)-green fluorescent protein (GFP) fusion, in which it appeared that $\mathrm{Msr}(\mathrm{D})$ directed Mef(E)-GFP to the cell poles, possibly assisting in the assembly of $\operatorname{Mef}(\mathrm{E})$ in the membrane and/or enhancing macrolide efflux as part of a composite transporter (Nunez-Samudio and Chesneau 2013).

Owing, in part, to the genomic plasticity and natural competency of $S$. pneumoniae, mega has been found in multiple chromosomal locations as well as inserted into other composite mobile elements carrying genetic markers of multiple Streptococcus species (Chancey et al. 2015a). Conjugal transfer rates of Tn1703.1 carrying mef(A) have been found to be highly variable between different $S$. pyogenes emm-types, ranging in frequencies of $1.13 \times 10^{-6}$ to $7.2 \times$ $10^{-8}$ in various isolates, with higher frequencies in emm 1 and emm4 isolates (Hadjirin et al. 2013). The mef(A) gene has also been found on a large chimeric chromosomal element that also carries the tet $(\mathrm{O})$ gene, an element that lends a distinct SmaI-typable pulse-field gel electrophoresis profile to isolates carrying the construct (Brenciani et al. 2004; Bacciaglia et al. 2007).

A novel mef(B) gene found in E. coli porcine isolates located near sul3 on plasmids has been described with $38 \%$ protein identity (62\% similarity) to $\operatorname{Mef}(\mathrm{A})$ (Liu et al. 2009a). When mef(B) was cloned into a plasmid and transformed into E. coli JM109, transformants had the $\mathrm{M}$ phenotype. The plasmid location as well as the genetic organization of the mef(B) gene were distinct from its organization in conjugative transposons. The GC content (44.95\%) was lower than that of E. coli, suggesting horizontal transition from another organism.
More recently, a novel subclass mef(C) gene was identified, along with a macrolide phosphotransferase $m p h(\mathrm{G})$, on plasmid pAQU1 isolated from marine bacteria including Vibrio and Photobacterium (Nonaka et al. 2015). Another subclass, termed mef(I) and first identified in isolates of S. pseudopneumoniae (Cochetti et al. 2005), has since been isolated from S. pneumoniae located on a novel IQ element inserted into defective Tn5252 and Tn916 sequences along with a unique $m s r(\mathrm{D})$ gene variant and catQ, a chloramphenicol acetyltransferase (Mingoia et al. 2007). The mef(O) subclass, which has a high degree of similarity to mef genes from $S$. dysgalactiae, was identified in $S$. pyogenes isolates from Norway (Sangvik 2005; Blackman Northwood et al. 2009). In addition to these, $m e f(\mathrm{~B})$ and $m e f(\mathrm{G})$ genes were identified in S. agalactiae and group G streptococci, respectively, conferring an $\mathrm{M}$ phenotype and showing high degrees of sequence identity to each other, although $<90 \%$ sequence identity to mef(A) or mef(E) (Amezaga and McKenzie 2006; Cai et al. 2007). However, mef(C), $m e f(\mathrm{G})$, mef( $\mathrm{I})$, and $m e f(\mathrm{O})$ have $>80 \%$ amino acid sequence homology with class mef(A), so none are recognized as a separate class at the website maintained by Marilyn Roberts (see faculty.washington.edu/marilynr; Roberts et al. 1999).

Derivatives of $S$. pyogenes sequence type 39 have been found carrying multiple mosaic mef gene variants encompassing the $5^{\prime}$ and terminal portions of mef(A) combined with a region of $m e f(\mathrm{E})$ spanning the majority of bases $570-$ 1100 (mef(A) sequence numbering used), often on a $\varphi \mathrm{m} 46.1$-like element and in conjunction with the tetracycline resistance gene tet $(\mathrm{O})$ (Blackman Northwood et al. 2009; Del Grosso et al. 2011). Some composite resistance genes containing mef-family sequences have been detected in which the $m s r(\mathrm{D})$ gene was not readily amplified by PCR; however, it was not clear whether this was because of sequence variance or absence of the genes (Cerda Zolezzi et al. 2004).

Induction of the $m e f(\mathrm{E})-m s r(\mathrm{D})$ operon has been linked to the presence of substrate macrolides (Daly et al. 2004; Ambrose et al. 2005; 
C. Fyfe et al.

Wierzbowski et al. 2005), with induction occurring by most 14 - and 15-membered macrolides, including ketolides (Chancey et al. 2011). The expression of the efflux operon in response to drug exposure appears to be correlated with the presence of a free hydroxyl at the $2^{\prime}$ position of a monosaccharide amino sugar like desosamine at position $\mathrm{C} 5$, rather than correlated to macrocyclic ring size or C3 sugar composition (see Fig. 1 for macrolide structures). For example, troleandomycin with an acetate substitution at the $2^{\prime}$ hydroxyl of desosamine, does not induce $m e f(\mathrm{E})-m s r(\mathrm{D})$ (Chancey et al. 2011) nor do the majority of 16-membered macrolides with a disaccharide at C5 (see Fig. 2 for 16-membered macrolide structures). mef(E)-msr(D)-inducing 16-membered macrolides, such as tilmicosin and rosamicin, and the 14-membered ketolide telithromycin have C5 monosaccharides that bind in the ribosome in locations similar to efflux substrates erythromycin and azithromycin, but distinct from weakly/noninducing macrolides with C5 disaccharides or modifications to C3 or C5 sugars (Chancey et al. 2011). Although both rosamicin and tilmicosin induced expression of $m e f(\mathrm{E}) / m s r(\mathrm{D})$, only tilmicosin appears to be a substrate for the $\operatorname{Mef}(\mathrm{E}) / \operatorname{Msr}(\mathrm{D})$ pumps (Chancey et al. 2011).

mef genes are regulated by transcription attenuation, with the induction of the $m e f(\mathrm{E}) /$ $m s r(\mathrm{D})$ operon occurring by anti-attenuation of transcription in the presence of inducing macrolides; however, there is also evidence that other regulatory mechanisms influence the control of $m e f(\mathrm{E}) / m s r(\mathrm{D})$. There is a leader peptide encoded $34 \mathrm{bp}$ upstream of the mef(E) start codon that is required for full expression of $m e f(\mathrm{E}) / m s r(\mathrm{D})$ (Subramaniam et al. 2011; Chancey et al. 2015b). Macrolide-bound ribosomes stall in the leader peptide, causing a shift in mRNA conformation, similar to induction of activity of erm methyltransferase genes (Chancey et al. 2015a). The mef(E) gene is also induced by unrelated structures such as LL-37, a cationic antimicrobial peptide produced in human macrophages, and two related murine homologs (Zahner et al. 2010). LL-37 may induce $m e f(\mathrm{E})$ by a different mechanism, but induction by either LL-37 or erythromycin confers resistance to both.

Msr Family. There are four macrolide efflux $m s r$ types, with each class having $\leq 80 \%$ amino acid homology with any member of any other type (see faculty.washington.edu/marilynr). All Msr classes have ATP-binding motif sequence homology with the ATP-binding transport superfamily (Ross et al. 1990). $m s r(\mathrm{~A})$ or $m s r(\mathrm{~B})$ genes (encoding a polypeptide homologous to the carboxyl terminus of $\operatorname{Msr}(\mathrm{A})$ ) were first identified in S. epidermidis and S. xylosus, respectively (Ross et al. 1990; Milton et al. 1992), but are now characterized as a single class. These genes have also been described in clinical S. aureus isolates (Wondrack et al. 1996; Matsuoka et al. 1999, 2003). The $m s r($ A) family genes confer resistance to 14- and 15-membered macrolides and streptogramin B (MS phenotype), and low-level resistance to ketolides (Ross et al. 1995, 1996; Wondrack et al. 1996; Canton et al. 2005; Reynolds and Cove 2005; Vimberg et al. 2015). Related msr-family efflux genes have been isolated from other genera, including Enterococcus ( $m s r(\mathrm{C})$, msr(A)), Streptococcus ( $m s r(\mathrm{D})$, also known as mel), Pseudomonas (msr(A)), Corynebacterium (msr(A)), and in various environmental isolates $(m s r(\mathrm{E}))$ (Portillo et al. 2000; Ojo et al. 2006; Varaldo et al. 2009; Desmolaize et al. 2011; Roberts 2011).

The structure of the $\operatorname{Msr}(\mathrm{A})$ protein is classified as a class $2 \mathrm{ABC}$-transporter, containing two ATP-binding domains and a long Q-linker region, but not a typical membrane-spanning region. Thus, there exists more than one hypothesized mechanism for $\operatorname{Msr}(\mathrm{A})$ function (Ross et al. 1995, 1996; Reynolds et al. 2003). Theories describing the mechanism of action for $\operatorname{Msr}(\mathrm{A})$-linked resistance involve interaction of $\operatorname{Msr}(\mathrm{A})$ with the ribosome, blocking binding to the $23 \mathrm{~S}$ rRNA target site that overlaps macrolides and streptogramin B, or an ATP-dependent efflux pump activity mediated by interaction with membrane-spanning binding proteins (possibly Mef(E)) (Kerr et al. 2005; Nunez-Samudio and Chesneau 2013), or as a structure that helps with the localization and/ or assembly of $\operatorname{Mef}(\mathrm{E})$ into the membrane (Nunez-Samudio and Chesneau 2013). Studies 
Resistance to Macrolide Antibiotics in Public Health Pathogens

with efflux pump inhibitors show $\operatorname{Msr}(\mathrm{A})$ function is uninhibited by reserpine, a common Gram-positive efflux pump inhibitor, but efflux activity was inhibited by arsenate, dinitrophenol, or CCCP, supporting the ATP-dependent function of the pump. To date, there has been no direct evidence to support the hypothesis of ribosome protection and recent evidence suggests that $\operatorname{Mef}(\mathrm{E})$ and $\operatorname{Msr}(\mathrm{D})$ may form a composite efflux pump (Nunez-Samudio and Chesneau 2013).

A recent study that examined the nature of telithromycin resistance in mutants selected in $S$. aureus RN4220 recombinantly expressing $m s r($ A) found that mutations mapped to $c l p X$, a protein that functions as both the substraterecognizing component of the ClpXP proteolytic system and as a ClpP-independent chaperone for protein-DNA and protein-protein complexes (Burton et al. 2001). The decreased susceptibility of telithromycin (and erythromycin) was $\operatorname{Msr}(\mathrm{A})$-mediated and related to loss-offunction mutations in ClpX only (Vimberg et al. 2015).

The $m s r(\mathrm{~A})$ gene was initially isolated on a S. epidermidis plasmid designated pUL5050, along with a single-domain ATP-binding protein $(\operatorname{stp} A)$ and a hydrophobic protein $(\operatorname{smp} A)$, which are similar to $S$. aureus chromosomal genes $s t p C$ and $\operatorname{smp} C$, but it was shown that these genes played no role in conferring macrolide resistance (Ross et al. 1996). A variety of hybrid resistance plasmids have been found carrying $m s r(\mathrm{~A})$ and similar genes along with other resistance elements; pMS97 carrying msr(A) and the macrolide-inactivating phosphotransferase $m p h(C)$ (Matsuoka et al. 2003) and hybrid plasmids mediating combinations of penicillinase, tetracycline-efflux, and ribosomal methylation functions (Argudin et al. 2014) as examples. Expression of $m s r(\mathrm{~A})$ is mediated in a similar manner to erm genes, via translation attenuation mechanisms, but requires higher amounts of inducer (Ross et al. 1990, 1996; Subramaniam et al. 2011). If the 320-bp control region upstream of $m s r(\mathrm{~A})$ is deleted, the strain is constitutively macrolide-streptogramin Bresistant, analogous to deletions or mutations that destroy the secondary structure that is at- tenuated by drug-dependent stalling within the leader peptide of erm genes.

\section{MACROLIDE INACTIVATION}

\section{Macrolide Esterases}

Inactivation of erythromycin by hydrolysis was first shown to be widespread in Enterobacteriaceae isolated from the human fecal flora and was usually associated with erythromycin therapy (Barthelemy et al. 1984; Andremont et al. 1985, 1986; Arthur and Courvalin 1986). Hydrolytic inactivation of macrolides by esterases specifically involves 14 - and 15-membered macrolides; josamycin, midecamycin, rosaramycin, and spiramycin are not substrates (Arthur and Courvalin 1986; Arthur et al. 1987; Morar et al. 2012).

Two plasmid-encoded esterases, ere(A) and ere(B), conferring high-level erythromycin resistance (MIC $\geq 1 \mathrm{mg} / \mathrm{mL}$ ), have been isolated from E. coli. The ere(A) gene on the self-transmissible plasmid pIP1100 encodes a product with a molecular weight of 37,765 . The ere(B) gene, encoding an enzyme with a molecular weight of 51,000 , was first identified on the self-transmissible plasmid pIP1527, which also contained the $\operatorname{erm}(\mathrm{B})$ gene, formerly known as erxA and ermAM, encoding an rRNA-methylating enzyme commonly found in streptococci (Arthur and Courvalin 1986). Based on GC content and codon usage, ere(A) (GC content $50 \%$ ) is thought to have originated in Gramnegative bacteria, whereas ere(B) (GC content $36 \%$ ), although originally discovered in E. coli, is thought to have originated from Gram-positive bacteria (Arthur et al. 1987). The gene for erm(B) is linked to ere(B) on plasmid pIP1527, and their physical linkage may be responsible for codissemination of the genes (Arthur et al. 1987). Similar codon usage in ere(B) and erm(B) suggests a similar Gram-positive bacterial origin; however, the separation of both genes on pIP1527 by GC-rich sequences suggests that both genes were integrated into plasmid pIP1527 by separate genetic events (Arthur and Courvalin 1986). It has been shown that coexpression of $\operatorname{ere}(\mathrm{B})$ and $\operatorname{erm}(\mathrm{B})$ more than 
C. Fyfe et al.

additively contributes to erythromycin resistance in E. coli (Arthur and Courvalin 1986).

Ere(A), a type I esterase, and $\operatorname{Ere}(B)$, a type II esterase, both hydrolyze the lactone ring in 14-membered macrolides (Morar et al. 2012); however, the two enzymes are only weakly related with $25 \%$ protein sequence identity. Using a genomic enzymology approach, the catalytic mechanisms of the "erythromycin esterase superfamily" enzymes were compared (Morar et al. 2012). Ere(A), Ere(B), and two related enzymes from Bacillus cereus, Bcr135 and Bcr136, whose three-dimensional structures had previously been determined, were studied. $\operatorname{Ere}(\mathrm{A}), \operatorname{Ere}(\mathrm{B})$, and Bcr136 were found to be distinct, with only Ere(A) inhibited by chelating agents and hypothesized to contain a noncatalytic metal. Data from kinetic, mutagenesis, and modeling studies are consistent with all of the erythromycin esterases sharing a common catalytic mechanism, and efforts to detect a tightly bound metal in Ere(B) and Bcr136 were unsuccessful, leaving the hypothesis that Ere enzymes do not require a metal ion for their catalytic mechanism. Thus, the metal dependence of Ere(A) may be structural. A histidine residue, $\mathrm{H}_{46}$ (Ere(B) numbering), was found to be essential for catalytic function and proposed to serve as a general base in the activation of a nucleophilic water molecule. $\operatorname{Ere}(\mathrm{A})$ and $\operatorname{Ere}(\mathrm{B})$ substrate profiles differed. Ere(B) inactivated erythromycin, clarithromycin, roxithromycin, and azithromycin, but was inactive against the ketolide telithromycin. $\operatorname{Ere}(\mathrm{A})$ was unable to inactivate either telithromycin or azithromycin.

In recent years, the ere(A2) gene, a variant of ere(A) located in a class 1 integron cassette, has been found in Enterobacter aerogenes, E. cloacae, E. coli, Klebsiella oxytoca, K. pneumoniae, Providencia stuartii, Pseudomonas spp., Salmonella enterica, and Vibrio cholera (Chang et al. 2000; Peters et al. 2001; Kim et al. 2002; Thungapathra et al. 2002; Plante et al. 2003; Verdet et al. 2006; Abbassi et al. 2008; Chen et al. 2009; Krauland et al. 2010). Although macrolide antibiotics are generally not used in the treatment of nongastrointestinal infections caused by enteric bacteria, the spread of ere(A2) in Enterobacteriaceae is concerning because macrolides are often used in the treatment of traveler's diarrhea, and erythromycin is a common treatment of cholera in children and pregnant women (see cdc.gov/ cholera/doc/recommend-anitbiotics-treatment .docx).

\section{Phosphotransferases}

Macrolide phosphotransferases are macrolideinactivating enzymes widespread in Gram-negative and Gram-positive bacteria (Sutcliffe and Leclercq 2002; Roberts 2008) that, by in silico analysis, are in the same family as aminoglycoside and protein kinases (Shakya and Wright 2010). The first reported purifications of macrolide- 2 -phosphotransferases were from macrolide-resistant E. coli, and this mechanism was soon shown to be prevalent in E. coli clinical isolates in Japan (O'Hara et al. 1989; Kono et al. 1992; Taniguchi et al. 2004). Macrolide $2^{\prime}$-phosphotransferases, commonly found on mobile genetic elements, are inducible (e.g., $m p h(\mathrm{~A}))$ or constitutively expressed (e.g., $m p h(\mathrm{~B}))$ intracellular enzymes capable of transferring the $\gamma$-phosphate of nucleotide triphosphate to the $2^{\prime}-\mathrm{OH}$ group of $14-, 15-$, and 16-membered-ring macrolide antibiotics, thereby disrupting the macrolide's key interaction with A2058. Although early studies showed Mph enzymes could use ATP, more recent work with $\mathrm{Mph}(\mathrm{A})$ has shown a preference for GTP under physiologically relevant in vitro assay conditions (Shakya and Wright 2010). Expression of $m p h(\mathrm{~A})$ is induced by erythromycin, and, recently, the structure of the $\operatorname{MphR}(\mathrm{A})$ repressor protein, a negative regulator of $m p h(\mathrm{~A})$ expression, has been solved uncomplexed and complexed with erythromycin to $2.00 \AA$ and $1.76 \AA$ resolutions, respectively (Zheng et al. 2009). Erythromycin binds with a stoichiometry of 1:1 to each monomer of the functional $\operatorname{MphR}(\mathrm{A})$ dimer in a large hydrophobic cavern composed of residues from $\alpha$ helices of one monomer and the dimeric interface of the other monomer that appears to close around the ligand as it binds (Zheng et al. 2009).

Seven distinct macrolide phosphotransferases have been identified to date (see faculty .washington.edu/marilynr). The first identified 
phosphotransferases, $\mathrm{Mph}(\mathrm{A})$ and $\mathrm{Mph}(\mathrm{B})$, share $37 \%$ amino acid identity (O'Hara et al. 1989; Kono et al. 1992). The G+C contents of the mph(A) gene (66\%) (Noguchi et al. 1995) and the $m p h(\mathrm{~B})$ gene $(38 \%)$ (Noguchi et al. 1996) differ significantly from each other and the $\mathrm{G}+\mathrm{C}$ content of $E$. coli chromosome (50\%) (Muto and Osawa 1987), suggesting an exogenous nature of their origins. The $m p h(\mathrm{~B})$ has been functionally expressed in both E. coli and S. aureus, providing a first indication of the potential promiscuity of this macrolide resistance mechanism (Noguchi et al. 1998). In contrast, the $m p h(\mathrm{~A})$ gene could be expressed in E. coli but not in S. aureus, presumably because of its relatively higher $\mathrm{G}+\mathrm{C}$ content relative to that of the S. aureus chromosome (33\%) (Muto and Osawa 1987). The $m p h(\mathrm{C})$ gene, formerly $m p h B M$, along with genes encoding the $\mathrm{Msr}(\mathrm{A})$ efflux pump, and Erm methyltransferase, were first identified as naturally occurring on a transmissible plasmid in $S$. aureus clinical isolate (Matsuoka et al. 1998). The sequence of $\mathrm{Mph}(\mathrm{C})$ showed $67 \%$ amino acid similarity to $\mathrm{Mph}$ (B) from E. coli. In this study, expression of $m p h(C)$ in $S$. aureus was shown to be highly dependent on the presence of a portion of the gene encoding the $\operatorname{Mrr}(\mathrm{A})$ efflux pump; however, the nature of this dependence is not fully understood (Matsuoka et al. 2003).

Of the two enzymes originally found in E. coli, $\mathrm{Mph}(\mathrm{A})$ preferentially phosphorylates 14- and 15-membered ring versus $16-\mathrm{mem}$ bered macrolides, whereas $\mathrm{Mph}(\mathrm{B})$ phosphorylates 14- and 16-membered macrolides efficiently (Kono et al. 1992; O'Hara and Yamamoto 1996). Clear substrate specificity of these enzymes was shown by recombinant overexpression of $m p h(\mathrm{~A}), m p h(\mathrm{~B})$, and $m p h(\mathrm{C})$ in an isogenic strain background using an effluxdeficient laboratory E. coli strain (Chesneau et al. 2007). This study found that $\mathrm{Mph}(\mathrm{A})$ conferred resistance to erythromycin, telithromycin, azithromycin, and spiramycin. The closely related $\mathrm{Mph}(\mathrm{B})$ and $\mathrm{Mph}(\mathrm{C})$ enzymes both conferred resistance to erythromycin, spiramycin, and telithromycin, but no activity against azithromycin was observed. Further, functional expression of $m p h(\mathrm{C})$ in E. coli showed phos- photransferase activity in the absence of $m s r(\mathrm{~A})$ (Chesneau et al. 2007); however, the same plasmid did not confer macrolide resistance in S. aureus for reasons unknown, similar to previous observations (Matsuoka et al. 2003).

Residues shown to be important for enzymatic activity were found in the same relative positions in an alignment of $\mathrm{Mph}(\mathrm{A}), \mathrm{Mph}(\mathrm{B})$, and $\mathrm{Mph}(\mathrm{C})$, making it difficult to attribute substrate specificities to specific sequence variations (Chesneau et al. 2007). Site-directed mutagenesis of five aspartic acid residues $\left(\mathrm{D}_{200}\right.$, $\mathrm{D}_{209}, \mathrm{D}_{219}, \mathrm{D}_{227}$, and $\mathrm{D}_{231}$ ) thought to be located in the active site of $\mathrm{Mph}(\mathrm{B})$ based on alignments with the aminoglycoside phosphotransferase $\operatorname{APH}\left(3^{\prime}\right)$-IIa (Wright and Thompson 1999), showed that replacements of all aspartic acid residues with alanine, except for $\mathrm{D}_{227}$, completely inactivated $\mathrm{Mph}(\mathrm{B})$. The $\mathrm{D}_{227} \mathrm{~A}$ mutant retained $7 \%$ of the wild-type activity and showed altered substrate specificity with regard to 16-membered ring macrolides, suggesting a role for $\mathrm{D}_{227}$ in substrate recognition (Taniguchi et al. 1999). A similar site-directed mutagenesis study investigated conserved histidines $\mathrm{H}_{198}$ and $\mathrm{H}_{205}$ located in the active site of $\mathrm{Mph}(\mathrm{B})$ (Taniguchi et al. 2004). In this study, an $\mathrm{H}_{198} \mathrm{~A}$ mutant retained $50 \%$ of the specific enzymatic activity, suggesting that $\mathrm{H}_{198}$ was not a catalytically essential residue. In contrast, the $\mathrm{H}_{205} \mathrm{~A}$ mutant retained only $0.7 \%$ of wild-type levels of activity, and an $\mathrm{H}_{205} \mathrm{~N}$ mutant retained greater than half of wild-type levels, suggesting that $\mathrm{H}_{205}$ was essential for catalysis. Based on alignments with the active site in the structure of an aminoglycoside phosphotransferase, $\mathrm{H}_{205}$ was proposed to contact the $\gamma$-phosphate of ATP through magnesium and aid in the transfer of phosphate from ATP to the 2'-hydroxyl of the desosamine.

Macrolide phosphotransferases are widespread in bacteria of clinical, veterinary, agricultural, and environmental origins. Genes encoding Mph enzymes are usually found on mobile genetic elements containing other macrolide resistance genes and genes conferring resistance to other antibiotic classes. The $m p h(\mathrm{~A})$ gene has been found on plasmids that encode CTX-M extended-spectrum $\beta$-lactamases originating 
C. Fyfe et al.

in E. coli ST131 (Woodford et al. 2009; Sandegren et al. 2012) and 16S rRNA methyltransferases (i.e., $\operatorname{arm} A$ ) that encode aminoglycoside resistance. The $m p h(\mathrm{~A})$ gene has also been detected in multidrug-resistant (MDR) and KPC carbapenemase-producing K. pneumoniae (Soge et al. 2006; Sandegren et al. 2012; Lee et al. 2014), Shigella spp. isolates (Boumghar-Bourtchai et al. 2008; Howie et al. 2010; Gaudreau et al. 2014), in globally collected MDR and susceptible E. coli isolates (Phuc Nguyen et al. 2009), as well as other Gram-negative pathogens.

The $m p h(\mathrm{C})$ gene appears to be widespread in staphylococci and has been found in isolates from horse skin (Schnellmann et al. 2006), bovine mastitis (Luthje 2006; Li et al. 2015), and dogs, cats, and pigs (Luthje and Schwarz 2007). $m p h(\mathrm{C})$ has also been identified in corynebacteria from healthy human skin (Szemraj et al. 2014) and, interestingly, in Stenotrophomonas maltophilia (Alonso et al. 2000).

A partial sequence of $m p h(\mathrm{D})$ (AB048591) has been described from Pseudomonas aeruginosa clinical isolate M398 from Japan (Nakamura et al. 2000). Inactivation of oleandomycin was dependent on either ATP or GTP addition to crude extracts and the inactivated product chromatographed with the standard oleadomy$\operatorname{cin} 2$ '-phosphate. Although the strain was resistant to 14-, 15-, and 16-membered macrolides, crude extracts only inactivated 14-membered macrolides, with some activity (15\% inactivation) toward azithromycin. Because this PCR product had only $53 \%$ identity with other $m p h$ genes, it was given a separate designation. Variants of this gene have also been described in E. coli, Klebsiella, Pantoeae, Proteus, and Stenotrophomonas (see faculty.washington.edu/ marilynr).

Macrolide phosphotransferase genes designated as $m p h(\mathrm{E})$ have been found in the chromosomes of Acinetobacter baumannii (Poirel et al. 2008) and bovine respiratory Pasturella multocida and Mannheimia haemolytica isolates (Desmolaize et al. 2011; Kadlec et al. 2011). They are also transferable on plasmids, including mobile, broad-host range IncP- $1 \beta$ plasmids, and have been described in Serratia marscescens (Bae et al. 2009), K. pneumoniae (Shen et al.
2009; Jiang et al. 2010), A. baumannii (Poirel et al. 2008; Zarrilli et al. 2008), E. coli (GenBank \#FJ187822, partial sequence) (Gonzalez-Zorn et al. 2005; Bercot et al. 2008), Citrobacter freundii (Golebiewski et al. 2007), and in plasmid DNA from uncultured bacterium from wastewater treatment facilities (Schluter et al. 2007; Szczepanowski et al. 2007) (note that although the investigators designate the $m p h$ gene as $m p h(\mathrm{E})$, it is listed at macrolide nomenclature center as $m p h(\mathrm{~F}))$. $m p h(\mathrm{~A})$ and $m p h(\mathrm{E})$ genes are often found in the context of a macrolide resistance operon, either $m p h(\mathrm{~A})-m r x-$ $m p h R(\mathrm{~A})$ or $m p h R(\mathrm{E})-m p h(\mathrm{E})-m r x(\mathrm{E})$, and the operons are bordered by inverted repeat motifs of IS elements, suggesting that the latter could play an important role in the acquisition and spread of these resistance genes (Noguchi et al. 1995; Poole et al. 2006; Szczepanowski et al. 2007). The deduced gene product of $m p h R$ is a transcriptional regulator (where studied, a negative regulator of $m p h(\mathrm{~A})$ gene expression; Noguchi et al. 2000) of the TetR/AcrR family, whereas the $m r x$ genes encode a putative transmembrane transport protein; both are needed for high-level expression of macrolide resistance.

The most recently identified macrolide phosphotransferase, $m p h(G)$, has been found in Vibrio spp. and photobacteria in the seawater of fish farms (Nonaka et al. 2015).

\section{SURVEILLANCE OF MACROLIDE RESISTANCE AND CHARACTERIZATION OF MOLECULAR MECHANISMS}

For treatment of community-acquired pneumonia, a 14- or 15-membered macrolide plus a $\beta$-lactam is part of the regimen for patients with risk factors and is recommended as a single agent in patients without risk factors (Mandell et al. 2007). In a study that assessed the macrolide failures in patients with pneumococcal bacteremia, mef(A) and erm(B) were equally overrepresented, but MIC increases $>1 \mu \mathrm{g} / \mathrm{mL}$ were not associated with any greater failure rate (Daneman et al. 2006), thus showing that the lower level resistance generally seen in pneumococci harboring mef(A) is clinically signif- 
icant. Mutations in 23S rRNA are more frequently found where there are chronic or prolonged treatment regimens, such as for $\mathrm{CF}$ patients and those with $M$. pneumoniae or H. pylori infections (Table 2). The studies can be difficult to compare as investigators choose different genes to monitor their surveillance population.

Surveillance studies (published largely in 2006-2015) find macrolide resistance rates ranging from $<10 \%$ (Columbia, Hidalgo et al. 2011; Alaska, Rudolph et al. 2013) to $>60 \%$ (Asia, Song et al. 2004; Lebanon, Taha et al. 2012) in pneumococci. For group A streptococci, there was also a wide range in macrolide-resistant rates, varying from 2\% (Utah, Rowe et al. 2009; Scotland, Amezaga and McKenzie 2006; The Netherlands, Buter et al. 2010 ) to $98 \%$ in S. pyogenes (Chengdu, China, Zhou et al. 2014). It has been shown that macrolide resistance rates can increase with erythromycin usage (Seppala et al. 1997) and intermediate/long-acting macrolide consumption (Italy, Cornaglia et al. 1996; Spain, PerezTrallero et al. 1998; Slovenia, Cizman et al. 2001), but not all countries have increasing macrolide resistance paralleling increase in macrolide consumption (Portugal, Silva-Costa et al. 2015). Clonality can also play a role as was seen in erythromycin-resistant $S$. pyogenes in Pittsburgh, where all of the macrolide resistance (48\%) was the result of a single strain of S. pyogenes (Martin et al. 2002), showing resistance rates in one city or small region are possibly not representative for an entire country. Other factors yet determined also play a role. The rates of macrolide resistance in group B streptococci, including S. agalactiae, range from $4 \%$ to 5\% (Scotland, Amezaga and McKenzie 2006; The Netherlands, Buter et al. 2010) to 40\% (France, Bergal et al. 2015; Tunisia, Hraoui et al. 2012) and viridans streptococci generally have higher rates, ranging from 27\% (Turkey, Ergin et al. 2006) to 63\% (Canada, Thornton et al. 2015). Thus, it is important to continue surveillance and monitor resistance rates locally and globally.

A high rate of azithromycin-resistant streptococci was resident and characterized in adults with $\mathrm{CF}$, with half of the isolates harboring A2058G or A2059G mutations in 23S rRNA (Thornton et al. 2015). In S. aureus isolates from adult and children patients with $\mathrm{CF}$ (Tkadlec et al. 2015), 52\% of the macrolideresistant isolates had 23S rRNA or L4 ribosomal mutations. Mechanisms of macrolide resistance appear to be different in Gram-negative isolates from children with CF (Roberts et al. 2011). In patients participating in a randomized placebo-controlled trial with azithromycin, there was $25.5 \%$ frank macrolide resistance in $H$. influenzae with all but one of the remaining isolates intermediate to azithromycin. Rather than ribosomal protein mutations, erm(B) and $\operatorname{erm}(\mathrm{F})$ were frequently identified, usually in combination with mef(A); 23S rRNA mutations were not interrogated.

The rates of macrolide resistance in methicillin-resistant S. aureus (MRSA) and coagulase-negative staphylococci remain high (44\%-100\%), with erm genes as the most predominant mechanisms. Macrolide resistance in MRSA is significantly higher than in methicillin-susceptible $S$. aureus (MSSA) and, in a recent study in Turkey, there was a sevenfold difference in macrolide resistance between MRSA and MSSA (Gul et al. 2008; Yildiz et al. 2014; Aydeniz Ozansoy et al. 2015). The rates of macrolide resistance in coagulase-negative staphylococci vary from 44\% (Staphylococcus saprophyticus, France, Le Bouter et al. 2011) to $100 \%$ (S. haemolyticus, Poland, Brzychczy-Wloch et al. 2013; S. hominis, Poland, Szczuka et al. 2015) in surveillance studies (Table 2). Msr-mediated efflux appears to be increasing in staphylococci, often in conjunction with an erm gene. A study of isolates collected from European hospitals in 1997-1998 found msr genes in only $13 \%$ of MSSA isolates and did not detect the gene in MRSA (Schmitz et al. 2000). Similarly, a surveillance of isolates from French hospitals published in 1999 showed only $2.1 \%$ of MRSA/ MSSA isolates carrying $m s r(\mathrm{~A})$ resistance genes (Lina et al. 1999). More recent studies have shown msr genes present at rates ranging from $1.6 \%$ (Iran, Shahsavan et al. 2012) to $79 \%$ (Spain, Argudin et al. 2014; Aydeniz Ozansoy et al. 2015) of S. aureus and 15\% (Tunisia, Bou- 
C. Fyfe et al.
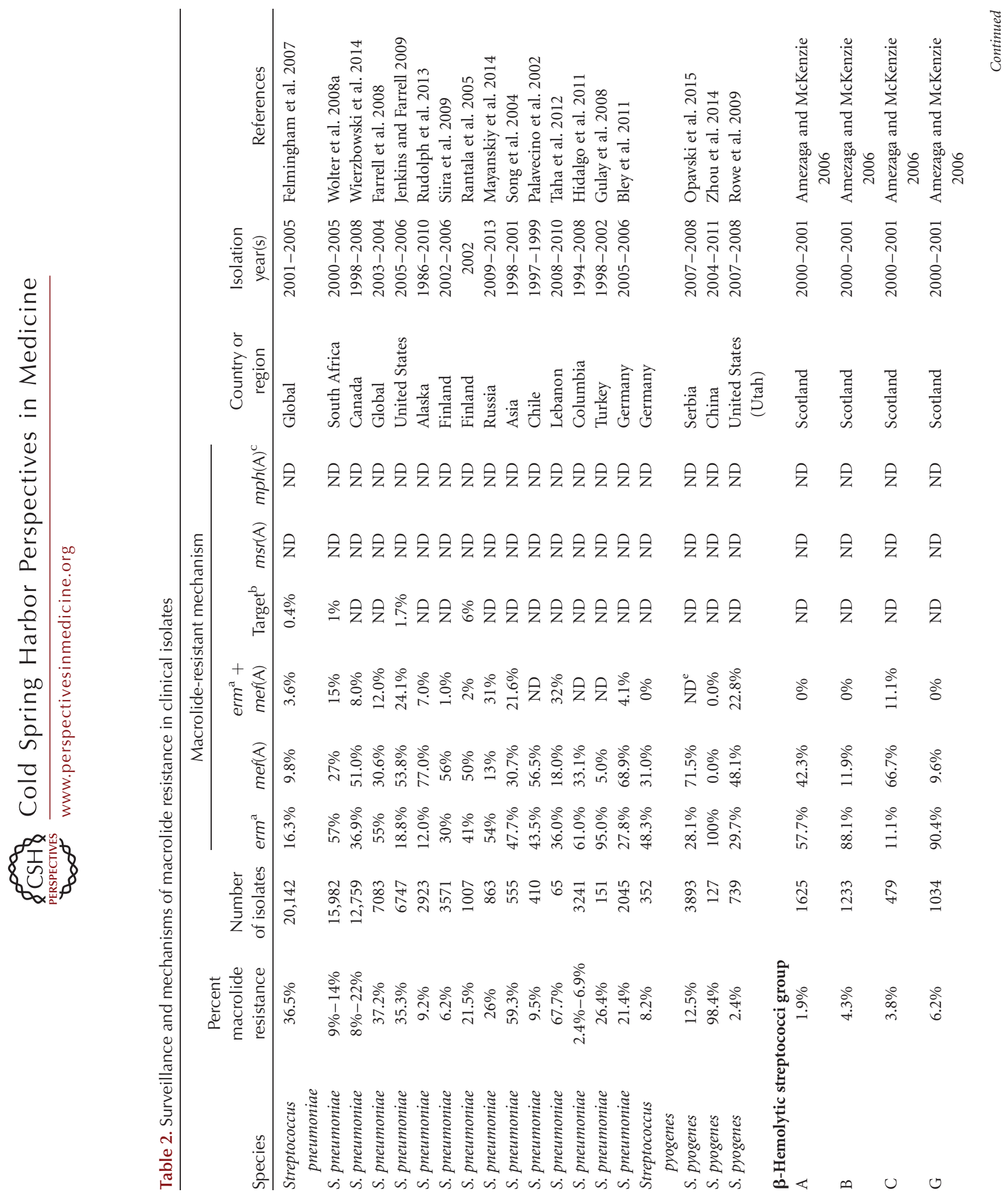
Resistance to Macrolide Antibiotics in Public Health Pathogens
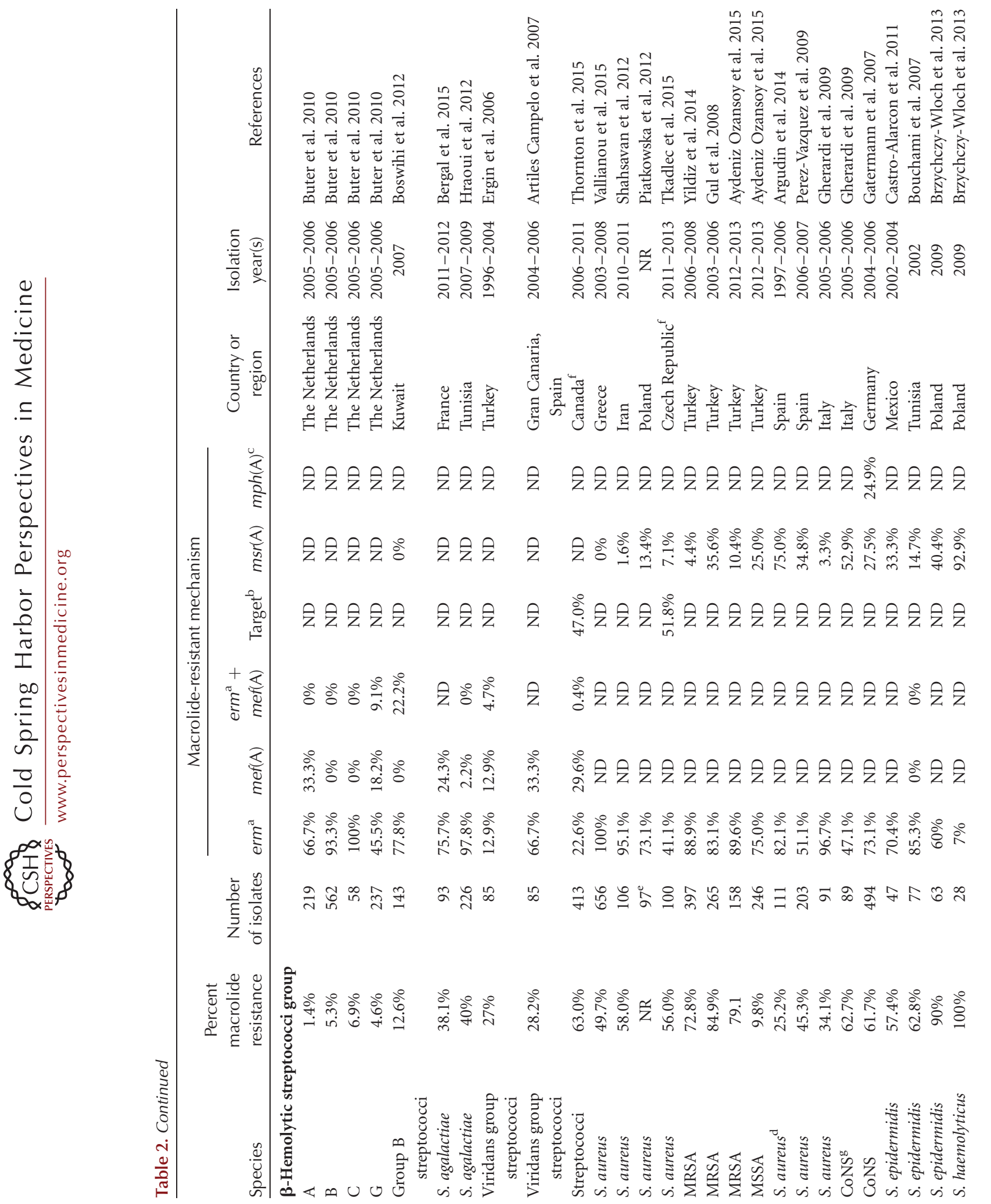
C. Fyfe et al.
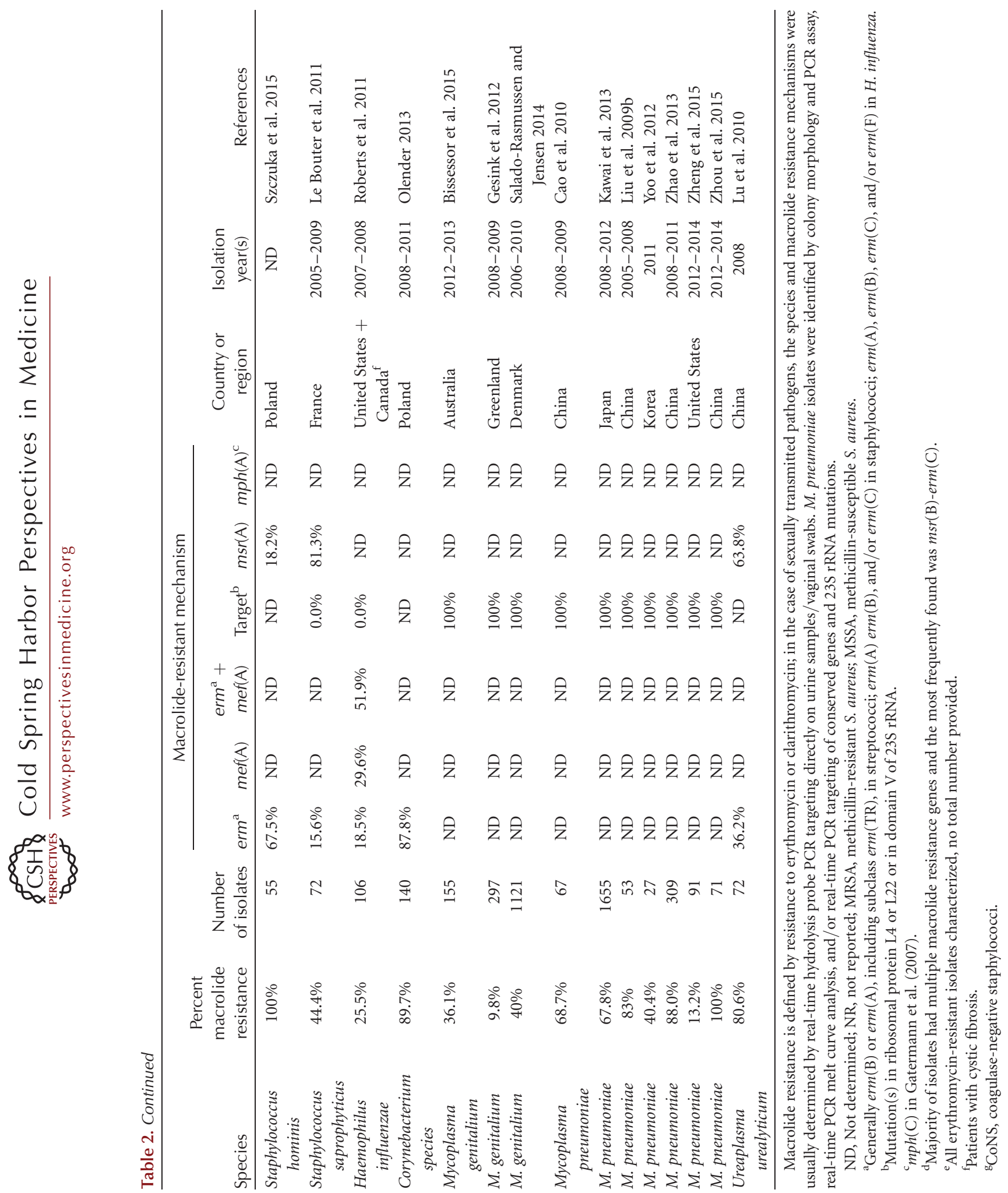
Resistance to Macrolide Antibiotics in Public Health Pathogens

chami et al. 2007) to $81 \%$ (France, Le Bouter et al. 2011) of coagulase-negative staphylococci (Gatermann et al. 2007; Perez-Vazquez et al. 2009; Le Bouter et al. 2011; Zmantar et al. 2011; Argudin et al. 2014).

Erythromycin, clarithromycin, and azithromycin are the therapeutic agents of choice for M. pneumoniae infections in children, and the first macrolide-resistant strain was isolated in Japan in 2000 (Okazaki et al. 2001). By 2003, $13 \%(13 / 76)$ of $M$. pneumoniae isolates in Japan were resistant to erythromycin (Matsuoka et al. 2004) with the majority $(n=10)$ associated with A2063G (A2058 E. coli numbering) and one each of A2063C, A2064G, and C2617G (C2611 E. coli numbering), with the latter only expressing weak resistant to erythromycin ( $\mathrm{MIC}=8 \mu \mathrm{g} / \mathrm{ml}$ ) (Tables 1 and 2). By 2008 , the prevalence had reached $30.6 \%$. Prevalence increased from 2008 to 2012 (Kawai et al. 2013 ) with regional differences of macrolide resistance, varying from $50 \%$ to $93 \%$, and with resistance rates higher in patients that had received macrolides before the surveillance study. The majority of the 561 isolates from 769 patients had mutations of A2063G or A2063T; less commonly, A2063C, A2064G, and C2617G were found. Rates of macrolide-resistant $M$. pneumoniae (MRMP) have exceeded $90 \%$ in Beijing, China (Zhao et al. 2013), with the majority of MRMP carrying the A2063G followed by A2064G and a single isolate with A2063T mutation. In Zhejiang, China, $100 \%$ of $M$. pneumoniae strains isolated from adults with community-acquired pneumonia carried the resistance determinant, A2063G mutation (Zhou et al. 2015).

Macrolides are often used for first-line therapies of Ureaplasma urealyticum infections. Interestingly, $80.6 \%$ of $U$. urealyticum in a 2008 study in China were macrolide-resistant (Lu et al. 2010). About 64\% of the isolates harbored $m s r(\mathrm{~A}) \pm m s r(\mathrm{D})$, whereas $36 \%$ carried $\operatorname{erm}(\mathrm{B})$, perhaps reflecting that this species can host plasmids and transposons. For M. genitalium, another causative agent of sexually transmitted infections, only $23 \mathrm{~S}$ rRNA mutations have been identified in macrolide-resistant isolates.

\section{CONCLUDING REMARKS}

Cryo-EM and X-ray crystallography have provided structural insights into how the ribosome interacts with and responds to small molecules like antibiotics. These studies help to explain how different target-based mutations or methylation of A2058 confer resistance, as well as provide an understanding into how regulation of erm methyltransferases and efflux genes has evolved. Along with the ribosome-macrolide Xray structures, we now have a much clearer understanding of how macrolides inhibit protein synthesis (i.e., the link between the ribosomal tunnel and the PTC) and the data show us that macrolide action is specific, targeting a subset of proteins. Assays could be developed to ensure that the synthesis of certain vital proteins is impacted and/or to monitor the mechanism(s) of action, potentially enriching for compounds that promote frameshifting, for example. The route to total synthesis will allow the exploration of structure-activity relationships, overcoming any limitations of semisynthesis (see macrolide.com; Zhang et al. 2016) and potentially extending spectrum beyond the community-acquired respiratory pathogens. With our present understanding, perhaps it is prime time to rethink macrolide drug discovery and use the existing and expanding tool sets to find molecules with more refined, targeted actions.

\section{ACKNOWLEDGMENTS}

The authors thank Philip C. Hogan, Macrolide Pharmaceuticals, for his chemistry prowess and review of macrolide structures, and Yury S. Polikanov, University of Illinois at Chicago, for his enthusiasm and expertise in producing Figure 3.

\section{REFERENCES}

* Reference is also in this collection.

Abbassi MS, Torres C, Achour W, Vinue L, Saenz Y, Costa D, Bouchami O, Ben Hassen A. 2008. Genetic characterisation of CTX-M-15-producing Klebsiella pneumoniae and Escherichia coli strains isolated from stem cell transplant patients in Tunisia. Int J Antimicrob Agents 32: 308-314. 
Alonso A, Sanchez P, Martinez JL. 2000. Stenotrophomonas maltophilia D457R contains a cluster of genes from Gram-positive bacteria involved in antibiotic and heavy metal resistance. Antimicrob Agents Chemother 44: 1778 1782.

Ambrose KD, Nisbet R, Stephens DS. 2005. Macrolide efflux in Streptococcus pneumoniae is mediated by a dual efflux pump (mel and mef) and is erythromycin inducible. Antimicrob Agents Chemother 49: 4203-4209.

Amezaga MR, McKenzie H. 2006. Molecular epidemiology of macrolide resistance in $\beta$-haemolytic streptococci of Lancefield groups A, B, C and G and evidence for a new mef element in group $\mathrm{G}$ streptococci that carries allelic variants of mef and msr(D). J Antimicrob Chemother 57: 443-449.

Andremont A, Gerbaud G, Tancrede C, Courvalin P. 1985. Plasmid-mediated susceptibility to intestinal microbial antagonisms in Escherichia coli. Infect Immun 49: 751 755.

Andremont A, Sancho-Garnier H, Tancrede C. 1986. Epidemiology of intestinal colonization by members of the family Enterobacteriaceae highly resistant to erythromycin in a hematology-oncology unit. Antimicrob Agents Chemother 29: 1104-1107.

* Arenz S, Wilson DN. 2016. Bacterial protein synthesis as a target for antibiotic inhibition. Cold Spring Harb Perspect Med doi: 10.1101/cshperspect.a025361.

Arenz S, Meydan S, Starosta AL, Berninghausen O, Beckmann R, Vazquez-Laslop N, Wilson DN. 2014a. Drug sensing by the ribosome induces translational arrest via active site perturbation. Mol Cell 56: 446-452.

Arenz S, Ramu H, Gupta P, Berninghausen O, Beckmann R, Vázquez-Laslop N, Mankin AS, Wilson DN. 2014b. Molecular basis for erythromycin-dependent ribosome stalling during translation of the ErmBL leader peptide. Nat Commun 5: 3501.

Argudin MA, Mendoza MC, Martin MC, Rodicio MR. 2014. Molecular basis of antimicrobial drug resistance in Staphylococcus aureus isolates recovered from young healthy carriers in Spain. Microb Pathog 74: 8-14.

Arthur M, Courvalin P. 1986. Contribution of two different mechanisms to erythromycin resistance in Escherichia coli. Antimicrob Agents Chemother 30: 694-700.

Arthur M, Brisson-Noel A, Courvalin P. 1987. Origin and evolution of genes specifying resistance to macrolide, lincosamide and streptogramin antibiotics: Data and hypotheses. J Antimicrob Chemother 20: 783-802.

Artiles Campelo F, Horcajada Herrera I, Alamo Antunez I, Canas Pedrosa A, Lafarga Capuz B. 2007. Phenotypes and genetic mechanisms of resistance to macrolides and lincosamides in viridans group streptococci. Rev Esp Quimioter 20: 317-322.

Aydeniz Ozansoy F, Cevahir N, Kaleli I. 2015. Investigation of macrolide, lincosamide and streptogramin B resistance in Staphylococcus aureus strains isolated from clinical samples by phenotypical and genotypical methods. Mikrobiyol Bul 49: 1-14.

Bacciaglia A, Brenciani A, Varaldo PE, Giovanetti E. 2007. SmaI typeability and tetracycline susceptibility and resistance in Streptococcus pyogenes isolates with efflux-mediated erythromycin resistance. Antimicrob Agents Chemother 51: 3042-3043.
Bae IK, Woo G-J, Park I, Jeong SH, Lee SH. 2009. Genetic environment of plasmid-mediated armA gene in Serratia marcescens clinical isolate. GenBank \#FJ917355.1.

Barthelemy P, Autissier D, Gerbaud G, Courvalin P. 1984. Enzymic hydrolysis of erythromycin by a strain of Escherichia coli. A new mechanism of resistance. J Antibiot (Tokyo) 37: 1692-1696.

Bebear CM, Pereyre S. 2005. Mechanisms of drug resistance in Mycoplasma pneumoniae. Curr Drug Targets Infect Disord 5: 263-271.

Bercot B, Poirel L, Nordmann P. 2008. Plasmid-mediated $16 \mathrm{~S}$ rRNA methylases among extended-spectrum $\beta$-lactamase-producing Enterobacteriaceae isolates. Antimicrob Agents Chemother 52: 4526-4527.

Bergal A, Loucif L, Benouareth DE, Bentorki AA, Abat C, Rolain JM. 2015. Molecular epidemiology and distribution of serotypes, genotypes, and antibiotic resistance genes of Streptococcus agalactiae clinical isolates from Guelma, Algeria and Marseille, France. Eur J Clin Microbiol Infect Dis 34: 2339-2348.

Bhushan S, Hoffmann T, Seidelt B, Frauenfeld J, Mielke T, Berninghausen O, Wilson DN, Beckmann R. 2011. SecM-stalled ribosomes adopt an altered geometry at the peptidyl transferase center. PLoS Biol 9: e1000581.

Bingen E, Leclercq R, Fitoussi F, Brahimi N, Malbruny B, Deforche D, Cohen R. 2002. Emergence of group A streptococcus strains with different mechanisms of macrolide resistance. Antimicrob Agents Chemother 46: 1199-1203.

Bissessor M, Tabrizi SN, Twin J, Abdo H, Fairley CK, Chen MY, Vodstrcil LA, Jensen JS, Hocking JS, Garland SM, et al. 2015. Macrolide resistance and azithromycin failure in a Mycoplasma genitalium-infected cohort and response of azithromycin failures to alternative antibiotic regimens. Clin Infect Dis 60: 1228-1236.

Blackman Northwood J, Del Grosso M, Cossins LR, Coley MD, Creti R, Pantosti A, Farrell DJ. 2009. Characterization of macrolide efflux pump mef subclasses detected in clinical isolates of Streptococcus pyogenes isolated between 1999 and 2005. Antimicrob Agents Chemother 53: $1921-$ 1925.

Blair JM, Richmond GE, Piddock LJ. 2014. Multidrug efflux pumps in Gram-negative bacteria and their role in antibiotic resistance. Future Microbiol 9: 1165-1177.

Bley C, van der Linden M, Reinert RR. 2011. mef(A) is the predominant macrolide resistance determinant in Streptococcus pneumoniae and Streptococcus pyogenes in Germany. Int J Antimicrob Agents 37: 425-431.

Boswihi SS, Udo EE, Al-Sweih N. 2012. Serotypes and antibiotic resistance in Group B streptococcus isolated from patients at the Maternity Hospital, Kuwait. J Med Microbiol 61: 126-131.

Bouchami O, Achour W, Ben Hassen A. 2007. Prevalence and mechanisms of macrolide resistance among Staphylococcus epidermidis isolates from neutropenic patients in Tunisia. Clin Microbiol Infect 13: 103-106.

Boumghar-Bourtchai L, Mariani-Kurkdjian P, Bingen E, Filliol I, Dhalluin A, Ifrane SA, Weill FX, Leclercq R. 2008. Macrolide-resistant Shigella sonnei. Emerg Infect Dis 14: 1297-1299.

Brenciani A, Ojo KK, Monachetti A, Menzo S, Roberts MC, Varaldo PE, Giovanetti E. 2004. Distribution and molecular analysis of mef(A)-containing elements in tetracy- 
cline-susceptible and -resistant Streptococcus pyogenes clinical isolates with efflux-mediated erythromycin resistance. J Antimicrob Chemother 54: 991-998.

Brockmann H, Henkel W. 1950. Pikromycin, ein neues Antibiotikum aus Actinomyceten. Naturwissenschaften 37: $138-139$.

Brzychczy-Wloch M, Borszewska-Kornacka M, Gulczynska E, Wojkowska-Mach J, Sulik M, Grzebyk M, Luchter M, Heczko PB, Bulanda M. 2013. Prevalence of antibiotic resistance in multi-drug resistant coagulase-negative staphylococci isolated from invasive infection in very low birth weight neonates in two Polish NICUs. Ann Clin Microbiol Antimicrob 12: 41.

Buriankova K, Doucet-Populaire F, Dorson O, Gondran A Ghnassia JC, Weiser J, Pernodet JL. 2004. Molecular basis of intrinsic macrolide resistance in the Mycobacterium tuberculosis complex. Antimicrob Agents Chemother 48: $143-150$.

Burman WJ, Stone BL, Brown BA, Wallace RJ Jr, Bottger EC 1998. AIDS-related Mycobacterium kansasii infection with initial resistance to clarithromycin. Diagn Microbiol Infect Dis 31: 369-371.

Burton BM, Williams TL, Baker TA. 2001. ClpX-mediated remodeling of $\mathrm{Mu}$ transpososomes: Selective unfolding of subunits destabilizes the entire complex. Mol Cell 8: 449-454.

Buter CC, Mouton JW, Klaassen CH, Handgraaf CM, Sunnen S, Melchers WJ, Sturm PD. 2010. Prevalence and molecular mechanism of macrolide resistance in $\beta$-haemolytic streptococci in The Netherlands. Int J Antimicrob Agents 35: 590-592.

Cai Y, Kong F, Gilbert GL. 2007. Three new macrolide efflux (mef) gene variants in Streptococcus agalactiae. J Clin Microbiol 45: 2754-2755.

Canton R, Mazzariol A, Morosini MI, Baquero F, Cornaglia G. 2005. Telithromycin activity is reduced by efflux in Streptococcus pyogenes. J Antimicrob Chemother 55: 489-495.

Canu A, Malbruny B, Coquemont M, Davies TA, Appelbaum PC, Leclercq R. 2000. Diversity of mutations in L22, L4 ribosomal proteins and 23S ribosomal RNA in pneumococcal mutants resistant to macrolides, telithromycin, and clindamycin selected in vitro. 40th Interscience Conference on Antimicrobial Agents and Chemotherapy (ICAAC), Abstract 1927. Toronto, September $17-20$.

Canu A, Malbruny B, Coquemont M, Davies TA, Appelbaum PC, Leclercq R. 2002. Diversity of ribosomal mutations conferring resistance to macrolides, clindamycin, streptogramin, and telithromycin in Streptococcus pneumoniae. Antimicrob Agents Chemother 46: 125-131.

Cao B, Zhao CJ, Yin YD, Zhao F, Song SF, Bai L, Zhang JZ, Liu YM, Zhang YY, Wang H, et al. 2010. High prevalence of macrolide resistance in Mycoplasma pneumoniae isolates from adult and adolescent patients with respiratory tract infection in China. Clin Infect Dis 51: 189-194.

Castro-Alarcon N, Ribas-Aparicio RM, Silva-Sanchez J, Calderon-Navarro A, Sanchez-Perez A, Parra-Rojas I, Aparicio-Ozores G. 2011. Molecular typing and characterization of macrolide, lincosamide and streptogramin resistance in Staphylococcus epidermidis strains isolated in a Mexican hospital. J Med Microbiol 60: 730-736.
Cerda Zolezzi P, Rubio Calvo MC, Millan L, Goni P, Canales M, Capilla S, Duran E, Gomez-Lus R. 2004. Macrolide resistance phenotypes of commensal viridans group streptococci and Gemella spp. and PCR detection of resistance genes. Int J Antimicrob Agents 23: 582-589.

Chancey ST, Zhou X, Zahner D, Stephens DS. 2011. Induction of efflux-mediated macrolide resistance in Streptococcus pneumoniae. Antimicrob Agents Chemother 55: 3413-3422.

Chancey ST, Agrawal S, Schroeder MR, Farley MM, Tettelin H, Stephens DS. 2015a. Composite mobile genetic elements disseminating macrolide resistance in Streptococcus pneumoniae. Front Microbiol 6: 26.

Chancey ST, Bai X, Kumar N, Drabek EF, Daugherty SC, Colon T, Ott S, Sengamalay N, Sadzewicz L, Tallon LJ, et al. 2015b. Transcriptional attenuation controls macrolide inducible efflux and resistance in Streptococcus pneumoniae and in other Gram-positive bacteria containing mef/mel(msr(D)) elements. PLoS ONE 10: e0116254.

Chang CY, Chang LL, Chang YH, Lee TM, Chang SF. 2000. Characterisation of drug resistance gene cassettes associated with class 1 integrons in clinical isolates of Escherichia coli from Taiwan, ROC. J Med Microbiol 49: 10971102.

Chen YT, Liao TL, Liu YM, Lauderdale TL, Yan JJ, Tsai SF 2009. Mobilization of qnrB2 and ISCR1 in plasmids. Antimicrob Agents Chemother 53: 1235-1237.

Chesneau O, Tsvetkova K, Courvalin P. 2007. Resistance phenotypes conferred by macrolide phosphotransferases. FEMS Microbiol Lett 269: 317-322.

Choi SS, Kim SK, Oh TG, Choi EC. 1997. Role of mRNA termination in regulation of ermK. J Bacteriol 179: 2065 2067.

Chrisment D, Charron A, Cazanave C, Pereyre S, Bebear C. 2012. Detection of macrolide resistance in Mycoplasma genitalium in France. J Antimicrob Chemother 67: 2598_2601.

Cizman M, Pokorn M, Seme K, Orazem A, Paragi M. 2001. The relationship between trends in macrolide use and resistance to macrolides of common respiratory pathogens. J Antimicrob Chemother 47: 475-477.

Clancy J, Petitpas J, Dib-Hajj F, Yuan W, Cronan M, Kamath AV, Bergeron J, Retsema JA. 1996. Molecular cloning and functional analysis of a novel macrolide-resistance determinant, mefA, from Streptococcus pyogenes. Mol Microbiol 22: $867-879$.

Clark C, Bozdogan B, Peric M, Dewasse B, Jacobs MR, Appelbaum PC. 2002. In vitro selection of resistance in Haemophilus influenzae by amoxicillin-clavulanate, cefpodoxime, cefprozil, azithromycin, and clarithromycin. Antimicrob Agents Chemother 46: 2956-2962.

Cochetti I, Vecchi M, Mingoia M, Tili E, Catania MR, Manzin A, Varaldo PE, Montanari MP. 2005. Molecular characterization of pneumococci with efflux-mediated erythromycin resistance and identification of a novel mef gene subclass, mef(I). Antimicrob Agents Chemother 49: 4999-5006.

Cornaglia G, Ligozzi M, Mazzariol A, Valentini M, Orefici G, Fontana R. 1996. Rapid increase of resistance to erythromycin and clindamycin in Streptococcus pyogenes in Italy, 1993-1995. The Italian Surveillance Group for Antimicrobial Resistance. Emerg Infect Dis 2: 339-342. 
Costa SS, Viveiros M, Amaral L, Couto I. 2013. Multidrug efflux pumps in Staphylococcus aureus: An update. Open Microbiol J 7: 59-71.

Culebras E, Rodriguez-Avial I, Betriu C, Picazo JJ. 2005. Differences in the DNA sequence of the translational attenuator of several constitutively expressed erm(A) genes from clinical isolates of Streptococcus agalactiae. J Antimicrob Chemother 56: 836-840.

Daly MM, Doktor S, Flamm R, Shortridge D. 2004. Characterization and prevalence of MefA, MefE, and the associated $m s r(\mathrm{D})$ gene in Streptococcus pneumoniae clinical isolates. J Clin Microbiol 42: 3570-3574.

Daneman N, McGeer A, Green K, Low DE. 2006. Macrolide resistance in bacteremic pneumococcal disease: implications for patient management. Clin Infect Dis 43: 432438.

Davydova N, Streltsov V, Wilce M, Liljas A, Garber M. 2002. L22 ribosomal protein and effect of its mutation on ribosome resistance to erythromycin. J Mol Biol 322: 635 644.

Debets-Ossenkopp YJ, Brinkman AB, Kuipers EJ, Vandenbroucke-Grauls CM, Kusters JG. 1998. Explaining the bias in the 23S rRNA gene mutations associated with clarithromycin resistance in clinical isolates of Helicobacter pylori. Antimicrob Agents Chemother 42: 2749 2751.

Del Grosso M, Iannelli F, Messina C, Santagati M, Petrosillo N, Stefani S, Pozzi G, Pantosti A. 2002. Macrolide efflux genes $m e f(\mathrm{~A})$ and $m e f(\mathrm{E})$ are carried by different genetic elements in Streptococcus pneumoniae. J Clin Microbiol 40: $774-778$.

Del Grosso M, Scotto d'Abusco A, Iannelli F, Pozzi G, Pantosti A. 2004. Tn2009, a Tn916-like element containing $m e f(\mathrm{E})$ in Streptococcus pneumoniae. Antimicrob Agents Chemother 48: 2037-2042.

Del Grosso M, Camilli R, Iannelli F, Pozzi G, Pantosti A 2006. The mef(E)-carrying genetic element (mega) of Streptococcus pneumoniae: Insertion sites and association with other genetic elements. Antimicrob Agents Chemother 50: 3361-3366.

Del Grosso M, Camilli R, Barbabella G, Blackman Northwood J, Farrell DJ, Pantosti A. 2011. Genetic resistance elements carrying mef subclasses other than mef(A) in Streptococcus pyogenes. Antimicrob Agents Chemother 55: 3226-3230.

Delmar JA, Su CC, Yu EW. 2014. Bacterial multidrug efflux transporters. Annu Rev Biophys 43: 93-117.

Depardieu F, Courvalin P. 2001. Mutation in 23S rRNA responsible for resistance to 16 -membered macrolides and streptogramins in Streptococcus pneumoniae. Antimicrob Agents Chemother 45: 319-323.

Depardieu F, Podglajen I, Leclercq R, Collatz E, Courvalin P. 2007. Modes and modulations of antibiotic resistance gene expression. Clin Microbiol Rev 20: 79-114.

Desmolaize B, Rose S, Wilhelm C, Warrass R, Douthwaite S. 2011. Combinations of macrolide resistance determinants in field isolates of Mannheimia haemolytica and Pasteurella multocida. Antimicrob Agents Chemother 55: 4128-4133.

Doktor SZ, Shortridge V. 2005. Differences in the DNA sequences in the upstream attenuator region of $\operatorname{erm}(\mathrm{A})$ in clinical isolates of Streptococcus pyogenes and their correlation with macrolide/lincosamide resistance. Antimicrob Agents Chemother 49: 3070-3072.

Doktor S, Shortridge V, Zhong P, Flamm R. 2001. Ribosomal mutations and macrolide-lincosamide resistance in Streptococcus pneumoniae. 41st Interscience Conference on Antimicrobial Agents and Chemotherapy (ICAAC), $\mathrm{Ab}$ stract C1-1812. Chicago, December 16-19.

Douthwaite S. 1992. Functional interactions within 23S rRNA involving the peptidyltransferase center. J Bacteriol 174: $1333-1338$

Douthwaite S, Jalava J, Jakobsen L. 2005. Ketolide resistance in Streptococcus pyogenes correlates with the degree of rRNA dimethylation by Erm. Mol Microbiol 58: 613-622.

Dunkle JA, Xiong L, Mankin AS, Cate JH. 2010. Structures of the Escherichia coli ribosome with antibiotics bound near the peptidyl transferase center explain spectra of drug action. Proc Natl Acad Sci 107: 17152-17157.

Ergin A, Ercis S, Hascelik G. 2006. Macrolide resistance mechanisms and in vitro susceptibility patterns of viridans group streptococci isolated from blood cultures. J Antimicrob Chemother 57: 139-141.

Ettayebi M, Prasad SM, Morgan EA. 1985. Chloramphenicol-erythromycin resistance mutations in a $23 \mathrm{~S}$ rRNA gene of Escherichia coli. J Bacteriol 162: 551-557.

Faccone D, Andres P, Galas M, Tokumoto M, Rosato A, Corso A. 2005. Emergence of a Streptococcus pneumoniae clinical isolate highly resistant to telithromycin and fluoroquinolones. J Clin Microbiol 43: 5800-5803.

Farrell DJ, Felmingham D. 2004. Activities of telithromycin against 13,874 Streptococcus pneumoniae isolates collected between 1999 and 2003. Antimicrob Agents Chemother 48: $1882-1884$.

Farrell DJ, Douthwaite S, Morrissey I, Bakker S, Poehlsgaard J, Jakobsen L, Felmingham D. 2003. Macrolide resistance by ribosomal mutation in clinical isolates of Streptococcus pneumoniae from the PROTEKT 1999-2000 study. Antimicrob Agents Chemother 47: 1777-1783.

Farrell DJ, Morrissey I, Bakker S, Buckridge S, Felmingham D. 2004. In vitro activities of telithromycin, linezolid, and quinupristin-dalfopristin against Streptococcus pneumoniae with macrolide resistance due to ribosomal mutations. Antimicrob Agents Chemother 48: 3169-3171.

Farrell DJ, Shackcloth J, Barbadora KA, Green MD. 2006. Streptococcus pyogenes isolates with high-level macrolide resistance and reduced susceptibility to telithromycin associated with $23 \mathrm{~S}$ rRNA mutations. Antimicrob Agents Chemother 50: 817-818.

Farrell DJ, Couturier C, Hryniewicz W. 2008. Distribution and antibacterial susceptibility of macrolide resistance genotypes in Streptococcus pneumoniae: PROTEKT Year 5 (2003-2004). Int J Antimicrob Agents 31: 245-249.

Farrell DJ, Mendes RE, Jones RN. 2015. Antimicrobial activity of solithromycin against serotyped macrolide-resistant Streptococcus pneumoniae isolates collected from U.S. medical centers in 2012. Antimicrob Agents Chemother 59: 2432-2434.

Felmingham D, Canton R, Jenkins SG. 2007. Regional trends in $\beta$-lactam, macrolide, fluoroquinolone and telithromycin resistance among Streptococcus pneumoniae isolates 2001-2004. J Infect 55: 111-118. 
Resistance to Macrolide Antibiotics in Public Health Pathogens

Franceschi F, Kanyo Z, Sherer EC, Sutcliffe J. 2004. Macrolide resistance from the ribosome perspective. Curr Drug Targets Infect Disord 4: 177-191.

Fu W, Anderson M, Williams S, Tait-Kamradt A, Sutcliffe J, Retsema J. 2000. In vitro derived macrolide-resistant Streptococcus pneumoniae strains have ribosomal mechanisms of resistance. 40th Interscience Conference on Antimicrobial Agents and Chemotherapy (ICAAC), Abstract 07-10. Toronto, September 17-20.

Fujisawa Y, Weisblum B. 1981. A family of r-determinants in Streptomyces spp. that specifies inducible resistance to macrolide, lincosamide, and streptogramin type B antibiotics. J Bacteriol 146: 621-631.

Garza-Ramos G, Xiong L, Zhong P, Mankin A. 2001. Binding site of macrolide antibiotics on the ribosome: New resistance mutation identifies a specific interaction of ketolides with rRNA. J Bacteriol 183: 6898-6907.

Gatermann SG, Koschinski T, Friedrich S. 2007. Distribution and expression of macrolide resistance genes in coagulase-negative staphylococci. Clin Microbiol Infect 13: 777-781.

Gaudreau C, Barkati S, Leduc JM, Pilon PA, Favreau J, Bekal S. 2014. Shigella spp. with reduced azithromycin susceptibility, Quebec, Canada, 2012-2013. Emerg Infect Dis 20: 854-856.

Gay K, Stephens DS. 2001. Structure and dissemination of a chromosomal insertion element encoding macrolide efflux in Streptococcus pneumoniae. J Infect Dis 184: 56-65.

Gesink DC, Mulvad G, Montgomery-Andersen R, Poppel U, Montgomery-Andersen S, Binzer A, Vernich L, Frosst G, Stenz F, Rink E, et al. 2012. Mycoplasma genitalium presence, resistance and epidemiology in Greenland. Int $J$ Circumpolar Health 71: 1-8.

Gherardi G, De Florio L, Lorino G, Fico L, Dicuonzo G. 2009. Macrolide resistance genotypes and phenotypes among erythromycin-resistant clinical isolates of Staphylococcus aureus and coagulase-negative staphylococci, Italy. FEMS Immunol Med Microbiol 55: 62-67.

Gibbons S, Oluwatuyi M, Kaatz GW. 2003. A novel inhibitor of multidrug efflux pumps in Staphylococcus aureus. J Antimicrob Chemother 51: 13-17.

Giovanetti E, Brenciani A, Lupidi R, Roberts MC, Varaldo PE. 2003. Presence of the tet $(\mathrm{O})$ gene in erythromycinand tetracycline-resistant strains of Streptococcus pyogenes and linkage with either the mef(A) or the erm(A) gene. Antimicrob Agents Chemother 47: 2844-2849.

Golebiewski M, Kern-Zdanowicz I, Zienkiewicz M, Adamczyk M, Zylinska J, Baraniak A, Gniadkowski M, Bardowski J, Ceglowski P. 2007. Complete nucleotide sequence of the pCTX-M3 plasmid and its involvement in spread of the extended-spectrum $\beta$-lactamase gene $b a_{\mathrm{CTX}-\mathrm{M}-3}$. Antimicrob Agents Chemother 51: 3789-3795.

Gong F, Yanofsky C. 2002. Instruction of translating ribosome by nascent peptide. Science 297: 1864-1867.

Gonzalez-Zorn B, Catalan A, Escudero JA, Dominguez L, Teshager T, Porrero C, Moreno MA. 2005. Genetic basis for dissemination of armA. J Antimicrob Chemother 56: $583-585$.

Gryczan TJ, Grandi G, Hahn J, Grandi R, Dubnau D. 1980. Conformational alteration of mRNA structure and the posttranscriptional regulation of erythromycin-induced drug resistance. Nucleic Acids Res 8: 6081-6097.
Gul HC, Kilic A, Guclu AU, Bedir O, Orhon M, Basustaoglu AC. 2008. Macrolide-lincosamide-streptogramin B resistant phenotypes and genotypes for methicillin-resistant Staphylococcus aureus in Turkey, from 2003 to 2006. Pol J Microbiol 57: 307-312.

Gulay Z, Ozbek OA, Bicmen M, Gur D. 2008. Macrolide resistance determinants in erythromycin-resistant Streptococcus pneumoniae in Turkey. Jpn J Infect Dis 61: 490493.

Gupta P, Kannan K, Mankin AS, Vazquez-Laslop N. 2013a. Regulation of gene expression by macrolide-induced ribosomal frameshifting. Mol Cell 52: 629-642.

Gupta P, Sothiselvam S, Vazquez-Laslop N, Mankin AS. 2013b. Deregulation of translation due to post-transcriptional modification of rRNA explains why erm genes are inducible. Nat Commun 4: 1984.

Gupta P, Liu B, Klepacki D, Gupta V, Schulten K, Mankin AS, Vazquez-Laslop N. 2016. Nascent peptide assists the ribosome in recognizing chemically distinct small molecules. Nat Chem Biol 12: 153-158.

Hadjirin NF, Harrison EM, Holmes MA, Paterson GK. 2013. Conjugative transfer frequencies of $m e f(\mathrm{~A})$-containing Tn1207.3 to macrolide-susceptible Streptococcus pyogenes belonging to different emm types. Lett Appl Microbiol 58: 299-302.

Hansen LH, Mauvais P, Douthwaite S. 1999. The macrolideketolide antibiotic binding site is formed by structures in domains II and V of $23 \mathrm{~S}$ ribosomal RNA. Mol Microbiol 31: 623-631.

Hansen JL, Ippolito JA, Ban N, Nissen P, Moore PB, Steitz TA. 2002. The structures of four macrolide antibiotics bound to the large ribosomal subunit. Mol Cell 10: 11128.

Hidalgo M, Santos C, Duarte C, Castaneda E, Agudelo CI. 2011. Increase in erythromycin-resistant Streptococcus pneumoniae in Colombia, 1994-2008. Biomedica 31: $124-131$.

Hook EW III, Golden M, Jamieson BD, Dixon PB, Harbison HS, Lowens S, Fernandes P. 2015. A phase 2 trial of oral solithromycin $1200 \mathrm{mg}$ or $1000 \mathrm{mg}$ as single-dose oral therapy for uncomplicated gonorrhea. Clin Infect Dis 61: 1043-1048.

Horinouchi S, Weisblum B. 1980. Posttranscriptional modification of mRNA conformation: Mechanism that regulates erythromycin-induced resistance. Proc Natl Acad Sci 77: 7079-7083.

Howie RL, Folster JP, Bowen A, Barzilay EJ, Whichard JM. 2010. Reduced azithromycin susceptibility in Shigella sonnei, United States. Microb Drug Resist 16: 245-248.

Hraoui M, Boutiba-Ben Boubaker I, Rachdi M, Slim A, Ben Redjeb S. 2012. Macrolide and tetracycline resistance in clinical strains of Streptococcus agalactiae isolated in Tunisia. J Med Microbiol 61: 1109-1113.

Hue KK, Bechhofer DH. 1992. Regulation of the macrolidelincosamide-streptogramin B resistance gene ermD. J Bacteriol 174: 5860-5868.

Hulten K, Gibreel A, Skold O, Engstrand L. 1997. Macrolide resistance in Helicobacter pylori: Mechanism and stability in strains from clarithromycin-treated patients. Antimicrob Agents Chemother 41: 2550-2553. 
C. Fyfe et al.

Ito K, Chiba S, Pogliano K. 2010. Divergent stalling sequences sense and control cellular physiology. Biochem Biophys Res Commun 393: 1-5.

Ito S, Shimada Y, Yamaguchi Y, Yasuda M, Yokoi S, Nakano M, Ishiko H, Deguchi T. 2011. Selection of Mycoplasma genitalium strains harbouring macrolide resistance-associated $23 \mathrm{~S}$ rRNA mutations by treatment with a single $1 \mathrm{~g}$ dose of azithromycin. Sex Transm Infect 87: 412-414.

Iwata S, Sato Y, Toyonaga Y, Hanaki H, Sunakawa K. 2015. Genetic analysis of a pediatric clinical isolate of Moraxella catarrhalis with resistance to macrolides and quinolones. J Infect Chemother 21: 308-311.

Jalava J, Vaara M, Huovinen P. 2004. Mutation at the position 2058 of the $23 \mathrm{~S}$ rRNA as a cause of macrolide resistance in Streptococcus pyogenes. Ann Clin Microbiol Antimicrob 3: 5.

Jenkins SG, Farrell DJ. 2009. Increase in pneumococcus macrolide resistance, United States. Emerg Infect Dis 15: $1260-1264$.

Jensen JS, Bradshaw CS, Tabrizi SN, Fairley CK, Hamasuna R. 2008. Azithromycin treatment failure in Mycoplasma genitalium-positive patients with nongonococcal urethritis is associated with induced macrolide resistance. Clin Infect Dis 47: 1546-1553.

Jensen JS, Fernandes P, Unemo M. 2014. In vitro activity of the new fluoroketolide solithromycin (CEM-101) against macrolide-resistant and -susceptible Mycoplasma genitalium strains. Antimicrob Agents Chemother 58: 31513156.

Jiang Y, Yu D, Wei Z, Shen P, Zhou Z, Yu Y. 2010. Complete nucleotide sequence of Klebsiella pneumoniae multidrug resistance plasmid pKP048, carrying $b l a_{\mathrm{KPC}-2}, b l a_{\mathrm{DHA}-1}$, qnrB4, and armA. Antimicrob Agents Chemother 54: 3967-3969.

Johansson M, Chen J, Tsai A, Kornberg G, Puglisi JD. 2014. Sequence-dependent elongation dynamics on macrolide-bound ribosomes. Cell Rep 7: 1534-1546.

Kadlec K, Brenner MG, Sweeney MT, Brzuszkiewicz E, Liesegang H, Daniel R, Watts JL, Schwarz S. 2011. Molecular basis of macrolide, triamilide, and lincosamide resistance in Pasteurella multocida from bovine respiratory disease. Antimicrob Agents Chemother 55: 2475-2477.

Kamimiya S, Weisblum B. 1997. Induction of ermSV by 16membered-ring macrolide antibiotics. Antimicrob Agents Chemother 41: 530-534.

Kannan K, Mankin AS. 2011. Macrolide antibiotics in the ribosome exit tunnel: Species-specific binding and action. Ann NY Acad Sci 1241: 33-47.

Kannan K, Vázquez-Laslop N, Mankin Alexander S. 2012. Selective protein synthesis by ribosomes with a drug-obstructed exit tunnel. Cell 151: 508-520.

Kannan K, Kanabar P, Schryer D, Florin T, Oh E, Bahroos N, Tenson T, Weissman JS, Mankin AS. 2014. The general mode of translation inhibition by macrolide antibiotics. Proc Natl Acad Sci 111: 15958-15963.

Karlsson M, Fellstrom C, Heldtander MU, Johansson KE, Franklin A. 1999. Genetic basis of macrolide and lincosamide resistance in Brachyspira (Serpulina) hyodysenteriae. FEMS Microbiol Lett 172: 255-260.

Kawai Y, Miyashita N, Kubo M, Akaike H, Kato A, Nishizawa Y, Saito A, Kondo E, Teranishi H, Wakabayashi T, et al.
2013. Nationwide surveillance of macrolide-resistant $M y$ coplasma pneumoniae infection in pediatric patients. Antimicrob Agents Chemother 57: 4046-4049.

Kelemen GH, Zalacain M, Culebras E, Seno ET, Cundliffe E. 1994. Transcriptional attenuation control of the tylosinresistance gene tlrA in Streptomyces fradiae. Mol Microbiol 14: 833-842.

Kerr ID, Reynolds ED, Cove JH. 2005. ABC proteins and antibiotic drug resistance: Is it all about transport? Biochem Soc Trans 33: 1000-1002.

Kim YH, Cha CJ, Cerniglia CE. 2002. Purification and characterization of an erythromycin esterase from an erythromycin-resistant Pseudomonas sp. FEMS Microbiol Lett 210: 239-244.

Kim JM, Kim JS, Kim N, Kim YJ, Kim IY, Chee YJ, Lee CH, Jung HC. 2008. Gene mutations of $23 \mathrm{~S}$ rRNA associated with clarithromycin resistance in Helicobacter pylori strains isolated from Korean patients. J Microbiol Biotechnol 18: 1584-1589.

Kono M, O’Hara K, Ebisu T. 1992. Purification and characterization of macrolide $2^{\prime}$-phosphotransferase type II from a strain of Escherichia coli highly resistant to macrolide antibiotics. FEMS Microbiol Lett 76: 89-94.

Krauland M, Harrison L, Paterson D, Marsh J. 2010. Novel integron gene cassette arrays identified in a global collection of multi-drug resistant non-typhoidal Salmonella enterica. Curr Microbiol 60: 217-223.

Kwak JH, Choi EC, Weisblum B. 1991. Transcriptional attenuation control of ermK, a macrolide-lincosamidestreptogramin B resistance determinant from Bacillus licheniformis. J Bacteriol 173: 4725-4735.

Lampson BC, Parisi JT. 1986. Naturally occurring Staphylococcus epidermidis plasmid expressing constitutive macrolide-lincosamide-streptogramin B resistance contains a deleted attenuator. J Bacteriol 166: 479-483.

Law CJ, Maloney PC, Wang DN. 2008. Ins and outs of major facilitator superfamily antiporters. Annu Rev Microbiol 62: 289-305.

Le Bouter A, Leclercq R, Cattoir V. 2011. Molecular basis of resistance to macrolides, lincosamides and streptogramins in Staphylococcus saprophyticus clinical isolates. Int J Antimicrob Agents 37: 118-123.

Leclercq R, Courvalin P. 2002. Resistance to macrolides and related antibiotics in Streptococcus pneumoniae. Antimicrob Agents Chemother 46: 2727-2734.

Lee Y, Kim BS, Chun J, Yong JH, Lee YS, Yoo JS, Yong D, Hong SG, D'Souza R, Thomson KS, et al. 2014. Clonality and resistome analysis of KPC-producing Klebsiella pneumoniae strain isolated in Korea using whole genome sequencing. Biomed Res Int 2014: 352862.

Li L, Feng W, Zhang Z, Xue H, Zhao X. 2015. Macrolidelincosamide-streptogramin resistance phenotypes and genotypes of coagulase-positive Staphylococcus aureus and coagulase-negative staphylococcal isolates from bovine mastitis. BMC Vet Res 11: 168.

Lina G, Quaglia A, Reverdy ME, Leclercq R, Vandenesch F Etienne J. 1999. Distribution of genes encoding resistance to macrolides, lincosamides, and streptogramins among staphylococci. Antimicrob Agents Chemother 43: $1062-$ 1066. 
Resistance to Macrolide Antibiotics in Public Health Pathogens

Liu M, Douthwaite S. 2002a. Methylation at nucleotide G745 or G748 in 23S rRNA distinguishes Gram-negative from Gram-positive bacteria. Mol Microbiol 44: 195-204.

Liu M, Douthwaite S. 2002b. Resistance to the macrolide antibiotic tylosin is conferred by single methylations at 23S rRNA nucleotides G748 and A2058 acting in synergy. Proc Natl Acad Sci 99: 14658-14663.

Liu J, Keelan P, Bennett PM, Enne VI. 2009a. Characterization of a novel macrolide efflux gene, mef(B), found linked to sul3 in porcine Escherichia coli. J Antimicrob Chemother 63: 423-426.

Liu Y, Ye X, Zhang H, Xu X, Li W, Zhu D, Wang M. 2009b. Antimicrobial susceptibility of Mycoplasma pneumoniae isolates and molecular analysis of macrolide-resistant strains from Shanghai, China. Antimicrob Agents Chemother 53: 2160-2162.

Llano-Sotelo B, Dunkle J, Klepacki D, Zhang W, Fernandes P, Cate JH, Mankin AS. 2010. Binding and action of CEM-101, a new fluoroketolide antibiotic that inhibits protein synthesis. Antimicrob Agents Chemother 54: 4961-4970.

Lodder G, Werckenthin C, Schwarz S, Dyke K. 1997. Molecular analysis of naturally occurring erm C-encoding plasmids in staphylococci isolated from animals with and without previous contact with macrolide/lincosamide antibiotics. FEMS Immunol Med Microbiol 18: 7-15.

Lovmar M, Nilsson K, Vimberg V, Tenson T, Nervall M, Ehrenberg M. 2006. The molecular mechanism of peptide-mediated erythromycin resistance. J Biol Chem 281: 6742-6750.

Lu C, Ye T, Zhu G, Feng P, Ma H, Lu R, Lai W. 2010. Phenotypic and genetic characteristics of macrolide and lincosamide resistant Ureaplasma urealyticum isolated in Guangzhou, China. Curr Microbiol 61: 44-49.

Lucier TS, Heitzman K, Liu SK, Hu PC. 1995. Transition mutations in the 23S rRNA of erythromycin-resistant isolates of Mycoplasma pneumoniae. Antimicrob Agents Chemother 39: 2770-2773.

Luthje P. 2006. Antimicrobial resistance of coagulase-negative staphylococci from bovine subclinical mastitis with particular reference to macrolide-lincosamide resistance phenotypes and genotypes. J Antimicrob Chemother 57: 966-969.

Luthje P, Schwarz S. 2007. Molecular basis of resistance to macrolides and lincosamides among staphylococci and streptococci from various animal sources collected in the resistance monitoring program BfT-GermVet. Int J Antimicrob Agents 29: 528-535.

Malbruny B, Nagai K, Coquemont M, Bozdogan B, Andrasevic AT, Hupkova H, Leclercq R, Appelbaum PC. 2002. Resistance to macrolides in clinical isolates of Streptococcus pyogenes due to ribosomal mutations. J Antimicrob Chemother 49: 935-939.

Mandell LA, Wunderink RG, Anzueto A, Bartlett JG, Campbell GD, Dean NC, Dowell SF, File TM Jr, Musher DM, Niederman MS, et al. 2007. Infectious Diseases Society of America/American Thoracic Society consensus guidelines on the management of community-acquired pneumonia in adults. Clin Infect Dis 44: S27-72.

Martin B, Alloing G, Mejean V, Claverys JP. 1987. Constitutive expression of erythromycin resistance mediated by the ermAM determinant of plasmid pAM $\beta 1$ results from deletion of $5^{\prime}$ leader peptide sequences. Plasmid 18: 250 253.

Martin JM, Green M, Barbadora KA, Wald ER. 2002. Erythromycin-resistant group A streptococci in schoolchildren in Pittsburgh. N Engl J Med 346: 1200-1206.

Matsuoka M, Endou K, Kobayashi H, Inoue M, Nakajima Y. 1998. A plasmid that encodes three genes for resistance to macrolide antibiotics in Staphylococcus aureus. FEMS Microbiol Lett 167: 221-227.

Matsuoka M, Janosi L, Endou K, Nakajima Y. 1999. Cloning and sequences of inducible and constitutive macrolide resistance genes in Staphylococcus aureus that correspond to an ABC transporter. FEMS Microbiol Lett 181: 91- 100.

Matsuoka M, Inoue M, Endo Y, Nakajima Y. 2003. Characteristic expression of three genes, $m s r(\mathrm{~A}), m p h(\mathrm{C})$ and $\operatorname{erm}(\mathrm{Y})$, that confer resistance to macrolide antibiotics on Staphylococcus aureus. FEMS Microbiol Lett 220: 287-293.

Matsuoka M, Narita M, Okazaki N, Ohya H, Yamazaki T, Ouchi K, Suzuki I, Andoh T, Kenri T, Sasaki Y, et al. 2004 Characterization and molecular analysis of macrolide-resistant Mycoplasma pneumoniae clinical isolates obtained in Japan. Antimicrob Agents Chemother 48: 4624-4630.

Mayanskiy N, Alyabieva N, Ponomarenko O, Lazareva A, Katosova L, Ivanenko A, Kulichenko T, Namazova-Baranova L, Baranov A. 2014. Serotypes and antibiotic resistance of non-invasive Streptococcus pneumoniae circulating in pediatric hospitals in Moscow, Russia. Int J Infect Dis 20: $58-62$.

Mayford M, Weisblum B. 1990. The ermC leader peptide: Amino acid alterations leading to differential efficiency of induction by macrolide-lincosamide-streptogramin B antibiotics. J Bacteriol 172: 3772-3779.

Meier A, Kirschner P, Springer B, Steingrube VA, Brown BA, Wallace RJ Jr, Bottger EC. 1994. Identification of mutations in 23S rRNA gene of clarithromycin-resistant $M y$ cobacterium intracellulare. Antimicrob Agents Chemother 38: $381-384$.

Menninger JR. 1985. Functional consequences of binding macrolides to ribosomes. J Antimicrob Chemother 16: 23-34.

Milton ID, Hewitt CL, Harwood CR. 1992. Cloning and sequencing of a plasmid-mediated erythromycin resistance determinant from Staphylococcus xylosus. FEMS Microbiol Lett 76: 141-147.

Min YH, Kwon AR, Yoon EJ, Shim MJ, Choi EC. 2008. Translational attenuation and mRNA stabilization as mechanisms of erm (B) induction by erythromycin. Antimicrob Agents Chemother 52: 1782-1789.

Mingoia M, Vecchi M, Cochetti I, Tili E, Vitali LA, Manzin A, Varaldo PE, Montanari MP. 2007. Composite structure of Streptococcus pneumoniae containing the erythromycin efflux resistance gene $m e f(\mathrm{I})$ and the chloramphenicol resistance gene catQ. Antimicrob Agents Chemother 51: 3983-3987.

Misyurina OY, Chipitsyna EV, Finashutina YP, Lazarev VN, Akopian TA, Savicheva AM, Govorun VM. 2004. Mutations in a $23 \mathrm{~S}$ rRNA gene of Chlamydia trachomatis associated with resistance to macrolides. Antimicrob Agents Chemother 48: 1347-1349. 
C. Fyfe et al.

Morar M, Pengelly K, Koteva K, Wright GD. 2012. Mechanism and diversity of the erythromycin esterase family of enzymes. Biochemistry 51: 1740-1751.

Morris RP, Nguyen L, Gatfield J, Visconti K, Nguyen K, Schnappinger D, Ehrt S, Liu Y, Heifets L, Pieters J, et al. 2005. Ancestral antibiotic resistance in Mycobacterium tuberculosis. Proc Natl Acad Sci 102: 12200-12205.

Murphy E. 1985. Nucleotide sequence of ermA, a macrolidelincosamide-streptogramin B determinant in Staphylococcus aureus. J Bacteriol 162: 633-640.

Muto A, Osawa S. 1987. The guanine and cytosine content of genomic DNA and bacterial evolution. Proc Natl Acad Sci 84: $166-169$

Nakamura A, Miyakozawa I, Nakazawa K, K OH, Sawai T. 2000. Detection and characterization of a macrolide $2^{\prime}$ phosphotransferase from a Pseudomonas aeruginosa clinical isolate. Antimicrob Agents Chemother 44: 3241-3242.

Nakatogawa H, Ito K. 2002. The ribosomal exit tunnel functions as a discriminating gate. Cell 108: 629-636.

Nash KA, Inderlied CB. 1995. Genetic basis of macrolide resistance in Mycobacterium avium isolated from patients with disseminated disease. Antimicrob Agents Chemother 39: 2625-2630.

Nash KA, Brown-Elliott BA, Wallace RJ Jr. 2009. A novel gene, $\operatorname{erm}(41)$, confers inducible macrolide resistance to clinical isolates of Mycobacterium abscessus but is absent from Mycobacterium chelonae. Antimicrob Agents Chemother 53: 1367-1376.

Ng LK, Martin I, Liu G, Bryden L. 2002. Mutation in 23S rRNA associated with macrolide resistance in Neisseria gonorrhoeae. Antimicrob Agents Chemother 46: 3020 3025.

Noguchi N, Emura A, Matsuyama H, O'Hara K, Sasatsu M, Kono M. 1995. Nucleotide sequence and characterization of erythromycin resistance determinant that encodes macrolide $2^{\prime}$-phosphotransferase I in Escherichia coli. Antimicrob Agents Chemother 39: 2359-2363.

Noguchi N, Katayama J, O’Hara K. 1996. Cloning and nucleotide sequence of the $m p h B$ gene for macrolide $2^{\prime}$ phosphotransferase II in Escherichia coli. FEMS Microbiol Lett 144: 197-202.

Noguchi N, Tamura Y, Katayama J, Narui K. 1998. Expression of the $m p h B$ gene for macrolide 2 '- phosphotransferase II from Escherichia coli in Staphylococcus aureus. FEMS Microbiol Lett 159: 337-342.

Noguchi N, Takada K, Katayama J, Emura A, Sasatsu M. 2000. Regulation of transcription of the $m p h(\mathrm{~A})$ gene for macrolide 2'-phosphotransferase I in Escherichia coli: Characterization of the regulatory gene $m p h R(\mathrm{~A})$. J Bacteriol 182: 5052-5058.

Nonaka L, Maruyama F, Suzuki S, Masuda M. 2015. Novel macrolide-resistance genes, $m e f(\mathrm{C})$ and $m p h(\mathrm{G})$, carried by plasmids from Vibrio and Photobacterium isolated from sediment and seawater of a coastal aquaculture site. Lett Appl Microbiol 61: 1-6.

Nunez-Samudio V, Chesneau O. 2013. Functional interplay between the ATP binding cassette Msr(D) protein and the membrane facilitator superfamily $\operatorname{Mef}(\mathrm{E})$ transporter for macrolide resistance in Escherichia coli. Res Microbiol 164: 226-235.
Occhialini A, Urdaci M, Doucet-Populaire F, Bebear CM, Lamouliatte H, Megraud F. 1997. Macrolide resistance in Helicobacter pylori: Rapid detection of point mutations and assays of macrolide binding to ribosomes. Antimicrob Agents Chemother 41: 2724-2728.

Oh TG, Kwon AR, Choi EC. 1998. Induction of ermAMR from a clinical strain of Enterococcus faecalis by 16-membered-ring macrolide antibiotics. J Bacteriol 180: 57885791.

O’Hara K, Yamamoto K. 1996. Reaction of roxithromycin and clarithromycin with macrolide-inactivating enzymes from highly erythromycin-resistant Escherichia coli. Antimicrob Agents Chemother 40: 1036-1038.

O'Hara K, Kanda T, Ohmiya K, Ebisu T, Kono M. 1989. Purification and characterization of macrolide 2'-phosphotransferase from a strain of Escherichia coli that is highly resistant to erythromycin. Antimicrob Agents Chemother 33: 1354-1357.

Ojo KK, Ulep C, Van Kirk N, Luis H, Bernardo M, Leitao J, Roberts MC. 2004. The mef(A) gene predominates among seven macrolide resistance genes identified in Gram-negative strains representing 13 genera, isolated from healthy Portuguese children. Antimicrob Agents Chemother 48: 3451-3456.

Ojo KK, Striplin MJ, Ulep CC, Close NS, Zittle J, Luis H, Bernardo M, Leitao J, Roberts MC. 2006. Staphylococcus efflux msr(A) gene characterized in Streptococcus, Enterococcus, Corynebacterium, and Pseudomonas isolates. Antimicrob Agents Chemother 50: 1089-1091.

Okazaki N, Narita M, Yamada S, Izumikawa K, Umetsu M, Kenri T, Sasaki Y, Arakawa Y, Sasaki T. 2001. Characteristics of macrolide-resistant Mycoplasma pneumoniae strains isolated from patients and induced with erythromycin in vitro. Microbiol Immunol 45: 617-620.

Olender A. 2013. Antibiotic resistance and detection of the most common mechanism of resistance $\left(\mathrm{MLS}_{\mathrm{B}}\right)$ of opportunistic Corynebacterium. Chemotherapy 59: 294306.

Oliveira SS, Murphy E, Gamon MR, Bastos MC. 1993. pRJ5: A naturally occurring Staphylococcus aureus plasmid expressing constitutive macrolide-lincosamide-streptogramin B resistance contains a tandem duplication in the leader region of the ermC gene. J Gen Microbiol 139: 1461-1467.

Oliveira CS, Moura A, Henriques I, Brown CJ, Rogers LM, Top EM, Correia A. 2013. Comparative genomics of IncP$1 \varepsilon$ plasmids from water environments reveals diverse and unique accessory genetic elements. Plasmid 70: 412-419.

Opavski N, Gajic I, Borek AL, Obszanska K, Stanojevic M, Lazarevic I, Ranin L, Sitkiewicz I, Mijac V. 2015. Molecular characterization of macrolide resistant Streptococcus pyogenes isolates from pharyngitis patients in Serbia Infect Genet Evol 33: 246-252.

Otaka T, Kaji A. 1975. Release of (oligo) peptidyl-tRNA from ribosomes by erythromycin A. Proc Natl Acad Sci 72: $2649-2652$.

Palavecino EL, Riedel I, Duran C, Bajaksouzian S, Joloba M, Davies T, Appelbaum PC, Jacobs MR. 2002. Macrolide resistance phenotypes in Streptococcus pneumoniae in Santiago, Chile. Int J Antimicrob Agents 20: 108-112.

Pao SS, Paulsen IT, Saier MH Jr. 1998. Major facilitator superfamily. Microbiol Mol Biol Rev 62: 1-34. 
Resistance to Macrolide Antibiotics in Public Health Pathogens

Paulsen IT, Brown MH, Skurray RA. 1996. Proton-dependent multidrug efflux systems. Microbiol Rev 60: 575608.

Pereyre S, Gonzalez P, De Barbeyrac B, Darnige A, Renaudin H, Charron A, Raherison S, Bebear C, Bebear CM. 2002. Mutations in 23S rRNA account for intrinsic resistance to macrolides in Mycoplasma hominis and Mycoplasma fermentans and for acquired resistance to macrolides in M. hominis. Antimicrob Agents Chemother 46: 31423150.

Perez-Trallero E, Urbieta M, Montes M, Ayestaran I, Marimon JM. 1998. Emergence of Streptococcus pyogenes strains resistant to erythromycin in Gipuzkoa, Spain. Eur J Clin Microbiol Infect Dis 17: 25-31.

Perez-Trallero E, Marimon JM, Iglesias L, Larruskain J. 2003. Fluoroquinolone and macrolide treatment failure in pneumococcal pneumonia and selection of multidrugresistant isolates. Emerg Infect Dis 9: 1159-1162.

Perez-Vazquez M, Vindel A, Marcos C, Oteo J, Cuevas O, Trincado P, Bautista V, Grundmann H, Campos J, Group ESs-t. 2009. Spread of invasive Spanish Staphylococcus aureus spa-type t067 associated with a high prevalence of the aminoglycoside-modifying enzyme gene ant $\left(4^{\prime}\right)$ $I a$ and the efflux pump genes $m s r A / m s r B$. J Antimicrob Chemother 63: 21-31.

Peric M, Bozdogan B, Jacobs MR, Appelbaum PC. 2003. Effects of an efflux mechanism and ribosomal mutations on macrolide susceptibility of Haemophilus influenzae clinical isolates. Antimicrob Agents Chemother 47: 1017-1022.

Peters ED, Leverstein-van Hall MA, Box AT, Verhoef J, Fluit AC. 2001. Novel gene cassettes and integrons. Antimicrob Agents Chemother 45: 2961-2964.

Peuchant O, Menard A, Renaudin H, Morozumi M, Ubukata K, Bebear CM, Pereyre S. 2009. Increased macrolide resistance of Mycoplasma pneumoniae in France directly detected in clinical specimens by real-time PCR and melting curve analysis. J Antimicrob Chemother 64: $52-$ 58.

Phuc Nguyen MC, Woerther PL, Bouvet M, Andremont A, Leclercq R, Canu A. 2009. Escherichia coli as reservoir for macrolide resistance genes. Emerg Infect Dis 15: 1648 1650.

Piatkowska E, Piatkowski J, Przondo-Mordarska A. 2012. The strongest resistance of Staphylococcus aureus to erythromycin is caused by decreasing uptake of the antibiotic into the cells. Cell Mol Biol Lett 17: 633-645.

Pihlajamaki M, Kataja J, Seppala H, Elliot J, Leinonen M, Huovinen P, Jalava J. 2002. Ribosomal mutations in Streptococcus pneumoniae clinical isolates. Antimicrob Agents Chemother 46: 654-658.

Plante I, Centron D, Roy PH. 2003. An integron cassette encoding erythromycin esterase, $\operatorname{ere}(\mathrm{A})$, from Providencia stuartii. J Antimicrob Chemother 51: 787-790.

Poirel L, Mansour W, Bouallegue O, Nordmann P. 2008. Carbapenem-resistant Acinetobacter baumannii isolates from Tunisia producing the OXA-58-like carbapenemhydrolyzing oxacillinase OXA-97. Antimicrob Agents Chemother 52: 1613-1617.

Poole TL, Callaway TR, Bischoff KM, Warnes CE, Nisbet DJ. 2006. Macrolide inactivation gene cluster $m p h A-m r x-$ $m p h R$ adjacent to a class 1 integron in Aeromonas hydro- phila isolated from a diarrhoeic pig in Oklahoma. J Antimicrob Chemother 57: 31-38.

Portillo A, Ruiz-Larrea F, Zarazaga M, Alonso A, Martinez JL, Torres C. 2000. Macrolide resistance genes in Enterococcus spp. Antimicrob Agents Chemother 44: 967-971.

Prunier AL, Malbruny B, Tande D, Picard B, Leclercq R. 2002. Clinical isolates of Staphylococcus aureus with ribosomal mutations conferring resistance to macrolides. Antimicrob Agents Chemother 46: 3054-3056.

Prunier AL, Trong HN, Tande D, Segond C, Leclercq R. 2005. Mutation of L4 ribosomal protein conferring unusual macrolide resistance in two independent clinical isolates of Staphylococcus aureus. Microb Drug Resist 11: $18-20$.

Ramu H, Mankin A, Vazquez-Laslop N. 2009. Programmed drug-dependent ribosome stalling. Mol Microbiol 71: 811-824.

Rantala M, Huikko S, Huovinen P, Jalava J. 2005. Prevalence and molecular genetics of macrolide resistance among Streptococcus pneumoniae isolates collected in Finland in 2002. Antimicrob Agents Chemother 49: 4180-4184.

Reinert RR, van der Linden M, Al-Lahham A. 2005. Molecular characterization of the first telithromycin-resistant Streptococcus pneumoniae isolate in Germany. Antimicrob Agents Chemother 49: 3520-3522.

Reynolds ED, Cove JH. 2005. Resistance to telithromycin is conferred by $m s r(\mathrm{~A}), m s r \mathrm{C}$ and $m s r(\mathrm{D})$ in Staphylococcus aureus. J Antimicrob Chemother 56: 1179-1180.

Reynolds E, Ross JI, Cove JH. 2003. Msr(A) and related macrolide/streptogramin resistance determinants: Incomplete transporters? Int J Antimicrob Agents 22: 228 236.

Rimbara E, Noguchi N, Kawai T, Sasatsu M. 2008. Novel mutation in $23 \mathrm{~S}$ rRNA that confers low-level resistance to clarithromycin in Helicobacter pylori. Antimicrob Agents Chemother 52: 3465-3466.

Roberts MC. 2008. Update on macrolide-lincosamidestreptogramin, ketolide, and oxazolidinone resistance genes. FEMS Microbiol Lett 282: 147-159.

Roberts MC. 2011. Environmental macrolide-lincosamidestreptogramin and tetracycline resistant bacteria. Front Microbiol 2: 40.

Roberts MC, Sutcliffe J, Courvalin P, Jensen LB, Rood J, Seppala H. 1999. Nomenclature for macrolide and macrolide-lincosamide-streptogramin B resistance determinants. Antimicrob Agents Chemother 43: 2823-2830.

Roberts MC, Soge OO, No DB. 2011. Characterization of macrolide resistance genes in Haemophilus influenzae isolated from children with cystic fibrosis. J Antimicrob Chemother 66: 100-104.

Rosato A, Vicarini H, Leclercq R. 1999. Inducible or constitutive expression of resistance in clinical isolates of streptococci and enterococci cross-resistant to erythromycin and lincomycin. J Antimicrob Chemother 43: 559-562.

Ross JI, Eady EA, Cove JH, Cunliffe WJ, Baumberg S, Wootton JC. 1990. Inducible erythromycin resistance in staphylococci is encoded by a member of the ATP-binding transport super-gene family. Mol Microbiol 4: 12071214.

Ross JI, Eady EA, Cove JH, Baumberg S. 1995. Identification of a chromosomally encoded ABC-transport system with 
C. Fyfe et al.

which the staphylococcal erythromycin exporter MsrA may interact. Gene 153: 93-98.

Ross JI, Eady EA, Cove JH, Baumberg S. 1996. Minimal functional system required for expression of erythromycin resistance by msrA in Staphylococcus aureus RN4220. Gene 183: 143-148.

Ross JI, Eady EA, Cove JH, Jones CE, Ratyal AH, Miller YW, Vyakrnam S, Cunliffe WJ. 1997. Clinical resistance to erythromycin and clindamycin in cutaneous propionibacteria isolated from acne patients is associated with mutations in $23 \mathrm{~S}$ rRNA. Antimicrob Agents Chemother 41: $1162-1165$.

Rowe RA, Stephenson RM, East DL, Wright S. 2009. Mechanisms of resistance for Streptococcus pyogenes in northern Utah. Clin Lab Sci 22: 39-44.

Rudolph K, Bulkow L, Bruce M, Zulz T, Reasonover A, Harker-Jones M, Hurlburt D, Hennessy T. 2013. Molecular resistance mechanisms of macrolide-resistant invasive Streptococcus pneumoniae isolates from Alaska, 1986 to 2010. Antimicrob Agents Chemother 57: 5415-5422.

Saito R, Nonaka S, Nishiyama H, Okamura N. 2012. Molecular mechanism of macrolide-lincosamide resistance in Moraxella catarrhalis. J Med Microbiol 61: 1435-1438.

Salado-Rasmussen K, Jensen JS. 2014. Mycoplasma genitalium testing pattern and macrolide resistance: A Danish nationwide retrospective survey. Clin Infect Dis 59: 2430.

Sandegren L, Linkevicius M, Lytsy B, Melhus A, Andersson DI. 2012. Transfer of an Escherichia coli ST131 multiresistance cassette has created a Klebsiella pneumoniae-specific plasmid associated with a major nosocomial outbreak. J Antimicrob Chemother 67: 74-83.

Sander P, Prammananan T, Meier A, Frischkorn K, Bottger EC. 1997. The role of ribosomal RNAs in macrolide resistance. Mol Microbiol 26: 469-480.

Sangvik M. 2005. $m e f(\mathrm{~A}), \operatorname{mef}(\mathrm{E})$ and a new mef allele in macrolide-resistant Streptococcus spp isolates from Norway. J Antimicrob Chemother 56: 841-846.

Santagati M, Iannelli F, Oggioni MR, Stefani S, Pozzi G 2000. Characterization of a genetic element carrying the macrolide efflux gene mef(A) in Streptococcus pneumoniae. Antimicrob Agents Chemother 44: 2585-2587.

Santagati M, Iannelli F, Cascone C, Campanile F, Oggioni MR, Stefani S, Pozzi G. 2003. The novel conjugative transposon Tn1207.3 carries the macrolide efflux gene mef(A) in Streptococcus pyogenes. Microb Drug Resist 9: 243-247.

Schlunzen F, Harms JM, Franceschi F, Hansen HA, Bartels H, Zarivach R, Yonath A. 2003. Structural basis for the antibiotic activity of ketolides and azalides. Structure 11: 329-338.

Schluter A, Szczepanowski R, Kurz N, Schneiker S, Krahn I, Puhler A. 2007. Erythromycin resistance-conferring plasmid prsb105, isolated from a sewage treatment plant, harbors a new macrolide resistance determinant, an integron-containing Tn402-like element, and a large region of unknown function. Appl Environ Microbiol 73: $1952-$ 1960.

Schmeing TM, Huang KS, Strobel SA, Steitz TA. 2005. An induced-fit mechanism to promote peptide bond formation and exclude hydrolysis of peptidyl-tRNA. Nature 438: $520-524$
Schmitz FJ, Sadurski R, Kray A, Boos M, Geisel R, Kohrer K, Verhoef J, Fluit AC. 2000. Prevalence of macrolide-resistance genes in Staphylococcus aureus and Enterococcus faecium isolates from 24 European university hospitals. J Antimicrob Chemother 45: 891-894.

Schnellmann C, Gerber V, Rossano A, Jaquier V, Panchaud Y, Doherr MG, Thomann A, Straub R, Perreten V. 2006. Presence of new mecA and $m p h(\mathrm{C})$ variants conferring antibiotic resistance in Staphylococcus spp. isolated from the skin of horses before and after clinic admission. J Clin Microbiol 44: 4444-4454.

* Schwarz S, Shen J, Kadlec K, Wang Y, Brenner Michael G, Feßler AT, Vester B. 2016. Lincosamides, streptogramins, phenicols, and pleuromutilins: Mode of action and mechanisms of resistance. Cold Spring Harb Perspect Med doi: 10.1101/cshperspect.a027037.

Seidelt B, Innis CA, Wilson DN, Gartmann M, Armache JP, Villa E, Trabuco LG, Becker T, Mielke T, Schulten K, et al. 2009. Structural insight into nascent polypeptide chainmediated translational stalling. Science 326: 1412-1415.

Seppala H, Klaukka T, Vuopio-Varkila J, Muotiala A, Helenius H, Lager K, Huovinen P. 1997. The effect of changes in the consumption of macrolide antibiotics on erythromycin resistance in group A streptococci in Finland. Finnish Study Group for antimicrobial resistance. N Engl J Med 337: 441-446.

Shahsavan S, Emaneini M, Noorazar Khoshgnab B, Khoramian B, Asadollahi P, Aligholi M, Jabalameli F, Eslampour MA, Taherikalani M. 2012. A high prevalence of mupirocin and macrolide resistance determinant among Staphylococcus aureus strains isolated from burnt patients. Burns 38: 378-382.

Shakya T, Wright GD. 2010. Nucleotide selectivity of antibiotic kinases. Antimicrob Agents Chemother 54: 19091913.

Shen P, Wei Z, Jiang Y, Du X, Ji S, Yu Y, Li L. 2009. Novel genetic environment of the carbapenem-hydrolyzing $\beta$ lactamase KPC-2 among Enterobacteriaceae in China. Antimicrob Agents Chemother 53: 4333-4338.

Shimada Y, Deguchi T, Nakane K, Yasuda M, Yokoi S, Ito S, Nakano M, Ishiko H. 2011. Macrolide resistance-associated 23S rRNA mutation in Mycoplasma genitalium, Japan. Emerg Infect Dis 17: 1148-1150.

Shoji T, Takaya A, Sato Y, Kimura S, Suzuki T, Yamamoto T 2015. RlmCD-mediated U747 methylation promotes efficient G748 methylation by methyltransferase RlmAII in $23 \mathrm{~S}$ rRNA in Streptococcus pneumoniae; interplay between two rRNA methylations responsible for telithromycin susceptibility. Nucleic Acids Res 43: 8964-8972.

Sigmund CD, Ettayebi M, Morgan EA. 1984. Antibiotic resistance mutations in $16 \mathrm{~S}$ and $23 \mathrm{~S}$ ribosomal RNA genes of Escherichia coli. Nucleic Acids Res 12: 4653-4663.

Siira L, Rantala M, Jalava J, Hakanen AJ, Huovinen P, Kaijalainen T, Lyytikainen O, Virolainen A. 2009. Temporal trends of antimicrobial resistance and clonality of invasive Streptococcus pneumoniae isolates in Finland, 2002 to 2006. Antimicrob Agents Chemother 53: 2066-2073.

Silva-Costa C, Friaes A, Ramirez M, Melo-Cristino J. 2015. Macrolide-resistant Streptococcus pyogenes: Prevalence and treatment strategies. Expert Rev Anti Infect Ther 13: $615-628$. 
Resistance to Macrolide Antibiotics in Public Health Pathogens

Simonovic M, Steitz TA. 2009. A structural view on the mechanism of the ribosome-catalyzed peptide bond formation. Biochim Biophys Acta 1789: 612-623.

Soge OO, Queenan AM, Ojo KK, Adeniyi BA, Roberts MC. 2006. CTX-M-15 extended-spectrum $\beta$-lactamase from Nigerian Klebsiella pneumoniae. J Antimicrob Chemother 57: $24-30$

Song JH, Chang HH, Suh JY, Ko KS, Jung SI, Oh WS, Peck KR, Lee NY, Yang Y, Chongthaleong A, et al. 2004. Macrolide resistance and genotypic characterization of Streptococcus pneumoniae in Asian countries: A study of the Asian Network for Surveillance of Resistant Pathogens (ANSORP). J Antimicrob Chemother 53: 457-463.

Sothiselvam S, Liu B, Han W, Ramu H, Klepacki D, Atkinson GC, Brauer A, Remm M, Tenson T, Schulten K, et al. 2014. Macrolide antibiotics allosterically predispose the ribosome for translation arrest. Proc Natl Acad Sci 111: 9804-9809.

Stamm LV, Bergen HL. 2000. A point mutation associated with bacterial macrolide resistance is present in both $23 \mathrm{~S}$ rRNA genes of an erythromycin-resistant Treponema pallidum clinical isolate. Antimicrob Agents Chemother 44: 806-807.

Stone GG, Shortridge D, Flamm RK, Versalovic J, Beyer J, Idler K, Zulawinski L, Tanaka SK. 1996. Identification of a $23 \mathrm{~S}$ rRNA gene mutation in clarithromycin-resistant Helicobacter pylori. Helicobacter 1: 227-228.

Subramaniam SL, Ramu H, Mankin AS. 2011. Inducible resistance to macrolide antibiotics. In Antibiotic drug discovery and development (ed. Dougherty TJ, Pucci MJ), pp 445-484. Springer, New York.

Sun J, Deng Z, Yan A. 2014. Bacterial multidrug efflux pumps: Mechanisms, physiology and pharmacological exploitations. Biochem Biophys Res Commun 453: 254267.

Sutcliffe J, Leclercq R, ed. 2002. Mechanisms of resistance to macrolides, lincosamides, and ketolides. In Macrolide antibiotics (ed. Schonfeld W, Kirst HA), pp. 281-317. Birkhauser Verlag, Basel, Switzerland.

Szczepanowski R, Krahn I, Bohn N, Puhler A, Schluter A. 2007. Novel macrolide resistance module carried by the IncP- $1 \beta$ resistance plasmid pRSB111, isolated from a wastewater treatment plant. Antimicrob Agents Chemother 51: 673-678.

Szczuka E, Makowska N, Bosacka K, Slotwinska A, Kaznowski A. 2015. Molecular basis of resistance to macrolides, lincosamides and streptogramins in Staphylococcus hominis strains isolated from clinical specimens. Folia Microbiol (Praha) 61: 143-147.

Szemraj M, Kwaszewska A, Pawlak R, Szewczyk EM. 2014. Macrolide, lincosamide, and streptogramin B resistance in lipophilic corynebacteria inhabiting healthy human skin. Microb Drug Resist 20: 404-409.

Taha N, Araj GF, Wakim RH, Kanj SS, Kanafani ZA, Sabra A, Khairallah MT, Nassar FJ, Shehab M, Baroud M, et al. 2012. Genotypes and serotype distribution of macrolide resistant invasive and non-invasive Streptococcus pneumoniae isolates from Lebanon. Ann Clin Microbiol Antimicrob 11: 2 .

Tait-Kamradt A, Clancy J, Cronan M, Dib-Hajj F, Wondrack L, Yuan W, Sutcliffe J. 1997. mefE is necessary for the erythromycin-resistant M phenotype in Streptococcus pneumoniae. Antimicrob Agents Chemother 41: 22512255.

Tait-Kamradt A, Davies T, Appelbaum PC, Depardieu F Courvalin P, Petitpas J, Wondrack L, Walker A, Jacobs MR, Sutcliffe J. 2000a. Two new mechanisms of macrolide resistance in clinical strains of Streptococcus pneumoniae from Eastern Europe and North America. Antimicrob Agents Chemother 44: 3395-3401.

Tait-Kamradt A, Davies T, Cronan M, Jacobs MR, Appelbaum PC, Sutcliffe J. 2000b. Mutations in 23S rRNA and ribosomal protein L4 account for resistance in pneumococcal strains selected in vitro by macrolide passage. Antimicrob Agents Chemother 44: 2118-2125.

Takaya A, Sato Y, Shoji T, Yamamoto T. 2013. Methylation of $23 \mathrm{~S}$ rRNA nucleotide G748 by RlmAII methyltransferase renders Streptococcus pneumoniae telithromycin susceptible. Antimicrob Agents Chemother 57: 3789-3796.

Taniguchi K, Nakamura A, Tsurubuchi K, Ishii A, O’Hara K, Sawai T. 1999. Identification of functional amino acids in the macrolide 2'-phosphotransferase II. Antimicrob Agents Chemother 43: 2063-2065.

Taniguchi K, Nakamura A, Tsurubuchi K, O'Hara K, Sawai T. 2004. The role of histidine residues conserved in the putative ATP-binding region of macrolide 2'-phosphotransferase II. FEMS Microbiol Lett 232: 123-126.

Tenson T, DeBlasio A, Mankin A. 1996. A functional peptide encoded in the Escherichia coli 23S rRNA. Proc Natl Acad Sci 93: 5641-5646.

Tenson T, Xiong L, Kloss P, Mankin AS. 1997. Erythromycin resistance peptides selected from random peptide libraries. J Biol Chem 272: 17425-17430.

Tenson T, Lovmar M, Ehrenberg M. 2003. The mechanism of action of macrolides, lincosamides and streptogramin $\mathrm{B}$ reveals the nascent peptide exit path in the ribosome. J Mol Biol 330: 1005-1014.

Thornton CS, Grinwis ME, Sibley CD, Parkins MD, Rabin HR, Surette MG. 2015. Antibiotic susceptibility and molecular mechanisms of macrolide resistance in streptococci isolated from adult cystic fibrosis patients. J Med Microbiol 64: 1375-1386.

Thungapathra M, Amita, Sinha KK, Chaudhuri SR, Garg P, Ramamurthy T, Nair GB, Ghosh A. 2002. Occurrence of antibiotic resistance gene cassettes aac $\left(6^{\prime}\right)-I b, d f r A 5$, $d f r A 12$, and ereA2 in class I integrons in non-O1, nonO139 Vibrio cholerae strains in India. Antimicrob Agents Chemother 46: 2948-2955.

Tkadlec J, Varekova E, Pantucek R, Doskar J, Ruzickova V, Botka T, Fila L, Melter O. 2015. Characterization of Staphylococcus aureus strains isolated from Czech cystic fibrosis patients: High rate of ribosomal mutation conferring resistance to $M L S_{B}$ antibiotics as a result of longterm and low-dose azithromycin treatment. Microb Drug Resist 21: 416-423.

Touati A, Peuchant O, Jensen JS, Bebear C, Pereyre S. 2014. Direct detection of macrolide resistance in Mycoplasma genitalium isolates from clinical specimens from France by use of real-time PCR and melting curve analysis. J Clin Microbiol 52: 1549-1555.

Tu D, Blaha G, Moore PB, Steitz TA. 2005. Structures of $\mathrm{MLS}_{\mathrm{B}} \mathrm{K}$ antibiotics bound to mutated large ribosomal subunits provide a structural explanation for resistance. Cell 121: 257-270 
Twin J, Jensen JS, Bradshaw CS, Garland SM, Fairley CK, Min LY, Tabrizi SN. 2012. Transmission and selection of macrolide resistant Mycoplasma genitalium infections detected by rapid high resolution melt analysis. PLOS ONE $7: 20$.

Vallianou N, Evangelopoulos A, Hadjisoteriou M, Avlami A, Petrikkos G. 2015. Prevalence of macrolide, lincosamide, and streptogramin resistance among staphylococci in a tertiary care hospital in Athens, Greece. J Chemother 27: 319-323.

Vannuffel P, Di Giambattista M, Morgan EA, Cocito C. 1992. Identification of a single base change in ribosomal RNA leading to erythromycin resistance. J Biol Chem 267: 8377-8382.

Varaldo PE, Montanari MP, Giovanetti E. 2009. Genetic elements responsible for erythromycin resistance in streptococci. Antimicrob Agents Chemother 53: 343-353.

Vazquez-Laslop N, Thum C, Mankin AS. 2008. Molecular mechanism of drug-dependent ribosome stalling. $\mathrm{Mol}$ Cell 30: 190-202.

Vazquez-Laslop N, Ramu H, Klepacki D, Kannan K, Mankin AS. 2010. The key function of a conserved and modified rRNA residue in the ribosomal response to the nascent peptide. EMBO J 29: 3108-3117.

Vazquez-Laslop N, Klepacki D, Mulhearn DC, Ramu H, Krasnykh O, Franzblau S, Mankin AS. 2011. Role of antibiotic ligand in nascent peptide-dependent ribosome stalling. Proc Natl Acad Sci 108: 10496-10501.

Verdet C, Benzerara Y, Gautier V, Adam O, Ould-Hocine Z Arlet G. 2006. Emergence of DHA-1-producing Klebsiella spp. in the Parisian region: Genetic organization of the ampC and $a m p R$ genes originating from Morganella morganii. Antimicrob Agents Chemother 50: 607-617.

Versalovic J, Osato MS, Spakovsky K, Dore MP, Reddy R, Stone GG, Shortridge D, Flamm RK, Tanaka SK, Graham DY. 1997. Point mutations in the 23S rRNA gene of $\mathrm{Hel}$ icobacter pylori associated with different levels of clarithromycin resistance. J Antimicrob Chemother 40: $283-$ 286.

Vester B, Douthwaite S. 2001. Macrolide resistance conferred by base substitutions in $23 \mathrm{~S}$ rRNA. Antimicrob Agents Chemother 45: 1-12.

Vester B, Garrett RA. 1987. A plasmid-coded and site-directed mutation in Escherichia coli 23S RNA that confers resistance to erythromycin: Implications for the mechanism of action of erythromycin. Biochimie 69: 891-900.

Vimberg V, Xiong L, Bailey M, Tenson T, Mankin A. 2004 Peptide-mediated macrolide resistance reveals possible specific interactions in the nascent peptide exit tunnel. Mol Microbiol 54: 376-385.

Vimberg V, Lenart J, Janata J, Balikova Novotna G. 2015 ClpP-independent function of ClpX interferes with telithromycin resistance conferred by $\mathrm{Msr}(\mathrm{A})$ in Staphylococcus aureus. Antimicrob Agents Chemother 59: 36113614.

Voss NR, Gerstein M, Steitz TA, Moore PB. 2006. The geometry of the ribosomal polypeptide exit tunnel. $J \mathrm{Mol}$ Biol 360: 893-906.

Wallace RJ Jr., Meier A, Brown BA, Zhang Y, Sander P, Onyi GO, Bottger EC. 1996. Genetic basis for clarithromycin resistance among isolates of Mycobacterium chelonae and
Mycobacterium abscessus. Antimicrob Agents Chemother 40: $1676-1681$.

Walsh F, Willcock J, Amyes S. 2003. High-level telithromycin resistance in laboratory-generated mutants of Streptococcus pneumoniae. J Antimicrob Chemother 52: 345-353.

Wang G, Taylor DE. 1998. Site-specific mutations in the $23 \mathrm{~S}$ rRNA gene of Helicobacter pylori confer two types of resistance to macrolide-lincosamide-streptogramin B antibiotics. Antimicrob Agents Chemother 42: 1952-1958.

Weisblum B. 1995a. Erythromycin resistance by ribosome modification. Antimicrob Agents Chemother 39: 577585.

Weisblum B. 1995b. Insights into erythromycin action from studies of its activity as inducer of resistance. Antimicrob Agents Chemother 39: 797-805.

Wierzbowski AK, Boyd D, Mulvey M, Hoban DJ, Zhanel GG. 2005. Expression of the mef(E) gene encoding the macrolide efflux pump protein increases in Streptococcus pneumoniae with increasing resistance to macrolides. Antimicrob Agents Chemother 49: 4635-4640.

Wierzbowski AK, Karlowsky JA, Adam HJ, Nichol KA, Hoban DJ, Zhanel GG. 2014. Evolution and molecular characterization of macrolide-resistant Streptococcus pneumoniae in Canada between 1998 and 2008. J Antimicrob Chemother 69: 59-66.

Wilson DN. 2009. The A-Z of bacterial translation inhibitors. Crit Rev Biochem Mol Biol 44: 393-433.

Wilson DN. 2014. Ribosome-targeting antibiotics and mechanisms of bacterial resistance. Nat Rev Microbiol 12: $35-48$.

Wolter N, Smith AM, Farrell DJ, Klugman KP. 2006. Heterogeneous macrolide resistance and gene conversion in the pneumococcus. Antimicrob Agents Chemother 50: 359-361.

Wolter N, Smith AM, Low DE, Klugman KP. 2007. Highlevel telithromycin resistance in a clinical isolate of Streptococcus pneumoniae. Antimicrob Agents Chemother 51: 1092-1095.

Wolter N, Smith AM, Farrell DJ, Northwood JB, Douthwaite S, Klugman KP. 2008a. Telithromycin resistance in Streptococcus pneumoniae is conferred by a deletion in the leader sequence of $\mathrm{erm}(\mathrm{B})$ that increases rRNA methylation. Antimicrob Agents Chemother 52: 435-440.

Wolter N, von Gottberg A, du Plessis M, de Gouveia L, Klugman KP. 2008b. Molecular basis and clonal nature of increasing pneumococcal macrolide resistance in South Africa, 2000-2005. Int J Antimicrob Agents 32: 62-67.

Wondrack L, Massa M, Yang BV, Sutcliffe J. 1996. Clinical strain of Staphylococcus aureus inactivates and causes efflux of macrolides. Antimicrob Agents Chemother 40: 992-998.

Woodford N, Carattoli A, Karisik E, Underwood A, Ellington MJ, Livermore DM. 2009. Complete nucleotide sequences of plasmids pEK204, pEK499, and pEK516, encoding CTX-M enzymes in three major Escherichia coli lineages from the United Kingdom, all belonging to the international O25:H4-ST131 clone. Antimicrob Agents Chemother 53: 4472-4482. 
Resistance to Macrolide Antibiotics in Public Health Pathogens

Wright GD, Thompson PR. 1999. Aminoglycoside phosphotransferases: Proteins, structure, and mechanism. Front Biosci 4: D9-D21.

Xin D, Mi Z, Han X, Qin L, Li J, Wei T, Chen X, Ma S, Hou A, Li G, et al. 2009. Molecular mechanisms of macrolide resistance in clinical isolates of Mycoplasma pneumoniae from China. Antimicrob Agents Chemother 53: 2158 2159 .

Xiong L, Shah S, Mauvais P, Mankin AS. 1999. A ketolide resistance mutation in domain II of $23 \mathrm{~S}$ rRNA reveals the proximity of hairpin 35 to the peptidyl transferase centre Mol Microbiol 31: 633-639.

Ye Y, Li S, Li Y, Ren T, Liu K. 2013. Mycoplasma pneumoniae 23S rRNA gene mutations and mechanisms of macrolide resistance. Lab Med 44: 63-68.

Yildiz O, Coban AY, Sener AG, Coskuner SA, Bayramoglu G Guducuoglu H, Ozyurt M, Tatman-Otkun M, Karabiber N, Ozkutuk N, et al. 2014. Antimicrobial susceptibility and resistance mechanisms of methicillin resistant Staphylococcus aureus isolated from 12 Hospitals in Turkey. Ann Clin Microbiol Antimicrob 13: 44.

Yoo SJ, Kim HB, Choi SH, Lee SO, Kim SH, Hong SB, Sung H, Kim MN. 2012. Differences in the frequency of $23 \mathrm{~S}$ rRNA gene mutations in Mycoplasma pneumoniae between children and adults with community-acquired pneumonia: Clinical impact of mutations conferring macrolide resistance. Antimicrob Agents Chemother 56: 6393-6396.

Yusupov MM, Yusupova GZ, Baucom A, Lieberman K, Earnest TN, Cate JH, Noller HF. 2001. Crystal structure of the ribosome at $5.5 \AA$ resolution. Science 292: 883-896.

Zahner D, Zhou X, Chancey ST, Pohl J, Shafer WM, Stephens DS. 2010. Human antimicrobial peptide LL-37 induces MefE/Mel-mediated macrolide resistance in
Streptococcus pneumoniae. Antimicrob Agents Chemother 54: 3516-3519.

Zarrilli R, Vitale D, Di Popolo A, Bagattini M, Daoud Z, Khan AU, Afif C, Triassi M. 2008. A plasmid-borne $b l a_{\mathrm{OXA}-58}$ gene confers imipenem resistance to Acinetobacter baumannii isolates from a Lebanese hospital. Antimicrob Agents Chemother 52: 4115-4120.

Zhang Z, Fukuzaki T, Myers AG. 2016. Synthesis of D-desosamine and analogs by rapid assembly of 3-amino sugars. Angew Chem Int Ed Engl 55: 523-527.

Zhao F, Liu G, Wu J, Cao B, Tao X, He L, Meng F, Zhu L, Lv M, Yin Y, et al. 2013. Surveillance of macrolide-resistant Mycoplasma pneumoniae in Beijing, China, from 2008 to 2012. Antimicrob Agents Chemother 57: 1521-1523.

Zheng J, Sagar V, Smolinsky A, Bourke C, LaRonde-LeBlanc N, Cropp TA. 2009. Structure and function of the macrolide biosensor protein, $\operatorname{MphR}(\mathrm{A})$, with and without erythromycin. J Mol Biol 387: 1250-1260.

Zheng X, Lee S, Selvarangan R, Qin X, Tang YW, Stiles J, Hong T, Todd K, Ratliff AE, Crabb DM, et al. 2015. Macrolide-resistant Mycoplasma pneumoniae, United States. Emerg Infect Dis 21: 1470-1472.

Zhou W, Jiang YM, Wang HJ, Kuang LH, Hu ZQ, Shi H, Shu M, Wa CM. 2014. Erythromycin-resistant genes in group A $\beta$-haemolytic Streptococci in Chengdu, Southwestern China. Indian J Med Microbiol 32: 290-293.

Zhou Z, Li X, Chen X, Luo F, Pan C, Zheng X, Tan F. 2015 Macrolide-resistant Mycoplasma pneumoniae in adults in Zhejiang, China. Antimicrob Agents Chemother 59: $1048-1051$.

Zmantar T, Kouidhi B, Miladi H, Bakhrouf A. 2011. Detection of macrolide and disinfectant resistance genes in clinical Staphylococcus aureus and coagulase-negative staphylococci. BMC Res Notes 4: 453. 


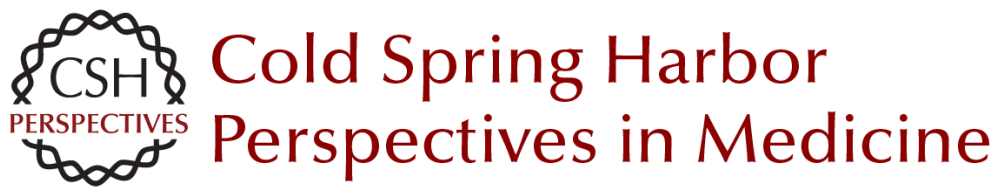

\section{Resistance to Macrolide Antibiotics in Public Health Pathogens}

Corey Fyfe, Trudy H. Grossman, Kathy Kerstein and Joyce Sutcliffe

Cold Spring Harb Perspect Med 2016; doi: 10.1101/cshperspect.a025395 originally published online August 15, 2016

\section{Subject Collection Antibiotics and Antibiotic Resistance}

Fosfomycin: Mechanism and Resistance Lynn L. Silver

Pleuromutilins: Potent Drugs for Resistant Bugs

--Mode of Action and Resistance Susanne Paukner and Rosemarie Riedl

Appropriate Targets for Antibacterial Drugs Lynn L. Silver

Lincosamides, Streptogramins, Phenicols, and Pleuromutilins: Mode of Action and Mechanisms of Resistance

Stefan Schwarz, Jianzhong Shen, Kristina Kadlec, et al.

Resistance to Macrolide Antibiotics in Public Health Pathogens

Corey Fyfe, Trudy H. Grossman, Kathy Kerstein, et al.

Bacterial Protein Synthesis as a Target for

Antibiotic Inhibition

Stefan Arenz and Daniel N. Wilson

Antibacterial Antifolates: From Development through Resistance to the Next Generation

Alexavier Estrada, Dennis L. Wright and Amy C. Anderson

Antibacterial Drug Discovery Targeting the Lipopolysaccharide Biosynthetic Enzyme LpxC Alice L. Erwin
The Whys and Wherefores of Antibiotic

Resistance

Cameron R. Strachan and Julian Davies

$\beta$-Lactamases: A Focus on Current Challenges Robert A. Bonomo

Approved Glycopeptide Antibacterial Drugs: Mechanism of Action and Resistance Daina Zeng, Dmitri Debabov, Theresa L. Hartsell, et al.

Mechanism of Action and Resistance to Daptomycin in Staphylococcus aureus and Enterococci William R. Miller, Arnold S. Bayer and Cesar A. Arias

Polymyxin: Alternative Mechanisms of Action and Resistance

Michael J. Trimble, Patrik Mlynárcik, Milan Kolár, et al.

Topoisomerase Inhibitors: Fluoroquinolone

Mechanisms of Action and Resistance David C. Hooper and George A. Jacoby

$\beta$-Lactams and $\beta$-Lactamase Inhibitors: An Overview Karen Bush and Patricia A. Bradford

Rifamycins, Alone and in Combination David M. Rothstein

For additional articles in this collection, see http://perspectivesinmedicine.cshlp.org/cgi/collection/ 